\title{
REDSNVED
}

FEB 121996

OSTI

\section{Comparison of Organic and Inorganic Ion Exchangers for Removal of Cesium and Strontium from Simulated and Actual Hanford 241-AW-101 DSSF Tank Waste}
G. N. Brown
R. J. Elovich
L. A. Bray
F. V.'Hoopes
C. D. Carlson
D. E. Kurath
K. J. Carson
L. L. Neńninger
J. R. DesChane
P. K. Tanaka :

January 1996

Prepared for the U.S. Department of Energy under Contract DE-AC06-76RLO 1830

Pacific Northwest National Laboratory Operated for the U.S. Department of Energy by Battelle Memorial Institute 


\section{DISCLAÍMER}

This report,was prepared as an account of work sponsured by an agency of the United States Govemment. Neither the United States Government nor any agency thereof, nor Battelle Memorial inśtitute, nor any of their employees, makes any warranty, express or implied, on assumes any legal liability or responsibility for the accuracy, completeness, or usefulness of any information, apparaftus, product, or process disclosed, or represents that its use would not infringe privately owned rights. Reference herein to any specific commercial product, process, or senvice by trade name, trademark, mañufacturer, or otherwise does not necessarily constitute or imply its endorsement, recommendation, ' or favoring by the United States Govemment or any agency thereof, or Battelle Memorial Institute. The views and opinions of authors expressed herein do not necessarily state or reflect those of the United Statés Government or any agency thereof.

\section{PACIFIC NORTHWEST NATIONALILABORÁTORY operated by

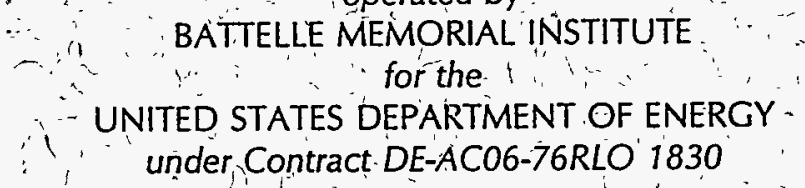

Printed in the United States of America

Available to DOE and DOE contractors from the

Office of Scientific and Techñical Ynformation, P.O. Box 62, Oák Ridge, TN 37831; prices available from (615) $576-8401$.

Available to the public from the National Technical Information Service, U.S. Department of Commerce, 5285 Pori Royal Rd., Springfield, $\vee A^{\prime} 22161$ 
Comparison of Organic and Inorganic Ion Exchangers for Removal of Cesium and Strontium from Simulated and Actual Hanford 241-AW-101 DSSF Tank Waste
G. N. Brown
L. A. Bray
C. D. Carlson
K. J. Carson
J. R. DesChane
R. J. Elovich
F. V. Hoopes
D. E. Kurath
L. L. Nenninger
P. K. Tanaka

January 1996

Prepared for

the U.S. Department of Energy

under Contract DE-AC06-76RLO 1830

Pacific Northwest National Laboratory

Richland, Washington 99352 



\section{Abstract}

This report describes the evaluation ' of seven ion exchange materials (CS-100, R-F SuperLig ${ }^{\circledR}$ 644, IE-910, IE-911, TIE-96 and NaTi) for the pretreatment of actual and simulated Hanford tank waste. The data presented here can be applied to the development and evaluation of pretreatment process flowsheets. Cesium and strontium batch distributions ratios $\left(\mathrm{K}_{\mathrm{d}}\right)$, column distribution ratios $\left(\lambda=. \mathrm{Kd} \times \rho_{\mathrm{b}}\right)$, and decontamination factors are compared as a function of solution composition, supernate:exchanger phase ratio, and multiple sequential contacts. The actual double-shell slurry feed waste is a volume composite from tanks 101-AW (70\%), 106-AP (20\%), and 102-AP (10\%) diluted to $4.96 \pm 0.19 \underline{\mathrm{M}} \mathrm{Na}$ with an initial $\mathrm{Na} / \mathrm{Cs}$ ratio of 78,000 . Simulant tests were conducted at waste dilutions ranging from 7 to $0.2 \underline{\mathrm{M}} \mathrm{Na}$ over a wide range of $\mathrm{Na} / \mathrm{Cs}$ mole ratios (50 to 500,000). For all materials, the cesium $\lambda$ values increased with $\mathrm{Na} / \mathrm{Cs}$ ratio (decreasing cesium concentration) and decreased with increasing sodium concentration. Cesium $\lambda$ values varied from 2 to $6.0 \mathrm{E}+04$ with the following order over most solution conditions: IE-910 $\approx$ IE-911 > SL-644 $\approx$ R-F $>$ TIE-96 > CS-100. In general, there was agreement between the cesium $\lambda$ results. obtained with the simulated and actual waste solutions.

All materials had an affinity for strontium, with the NaTi providing the greatest removal followed by IE-911, IE-910, and TIE-96. The organic exchangers exhibited relatively low affinities and would not be useful for strontium removal. The actual waste strontium $\lambda$ results were significantly lower than those obtained during simulant testing and are likely due to higher levels of organic materials or nonradioactive strontium in the actual waste solution. Based on the actual waste ICP results, the organic ion exchangers remove chromium, nickel, and beryllium (SL-644 > R-F > CS-100). In addition, zirconium was removed by all of the materials except IE-911, with the following order: NaTi $\approx$ TIE-96 $>$ SL-644 $>$ R-F $\approx$ CS-100 $>$ IE-910. These data suggest that future testing will be necessary to address the issue of significant metals . uptake. 


\section{Summary.}

Pacific Northwest National Laboratory (Northwest National Laboratory) conducted this study as a joint effort between the "Develop and Test Sorbents" task for the Efficient Separations and Processing Cross-Cutting Program (ESP) and the "Batch Testing of Crystalline Silico-Titanates (CSTs)" subtask, which is part of the Northwest National Laboratory Tank Waste Remediation System (TWRS) Pretreatment Technology Development Project. The objective of the study is to investigate radionuclide uptake of the newly produced CST materials under a variety of solution conditions and to compare the results obtained for this material with those obtained for other commercial and experimental exchangers.

A number of organic and inorganic exchangers are being developed and evaluated for the . removal of ${ }^{137} \mathrm{Cs},{ }^{90} \mathrm{Sr}$, and other radionuclides from Hanford tank wastes. The exchangers investigated in this work include powdered (IONSIV ${ }^{\circledR}$ IE-910, referred to as IE-910) and two batches of the engineered [IONSIV ${ }^{\circledR}$ IE-911, referred to as IE-911 (08) and IE-911 (38B)] forms of the inorganic CST sorbent developed by Sandia National Laboratories/Texas A\&M and prepared by UOP; a phenol-formaldehyde resin (CS-100 developed by Rohm and Haas; a resorcinolformaldehyde (R-F) polymer developed at the Westinghouse Savannah River Company and produced by Boulder Scientific; an inorganic zeolite exchanger produced by UOP (IONSIV TIE96, referred to as TIE-96); an inorganic sodium titanate produced by Allied Signal/Texas A\&M (NaTi); and a macrocyclic organic resin developed and produced by IBC Advanced Technologies (SuperLig ${ }^{\oplus}$ 644, referred to as SL-644). Several of these materials are still under development and may not be in the optimal form. UOP has further developed the IE-911 with improved kinetics, and samples are expected to be available in January 1996.

The work described in this report involves the direct comparison of these materials for the pretreatment of actual and simulated Hanford tank waste. Cesium and strontium $\mathrm{K}_{\mathrm{d}}$ 's, column distribution ratios $\left(\lambda=K_{d} \times \beta_{B}\right)$, and decontamination factors (DF) are compared as a function of contact duration, solution composition, supernate:exchanger phase ratio, and multiple sequential contacts. The actual double shell slurry feed waste is a volume composite from tanks 101-AW (70\%), 106-AP (20\%), and 102-AP (10\%). The actual waste tests were conducted at $4.96 \pm 0.19$ $\underline{\mathrm{M}} \mathrm{Na}$ and $23^{\circ} \mathrm{C}$ with $\mathrm{Na} / \mathrm{Cs}$ mole ratios that ranged from 100 to 500,000 . The simulant composition was formulated based on previous analytical characterization of the actual waste, and tests were conducted at dilutions ranging from 7 to $0.2 \mathrm{M} \mathrm{Na}$, over a wide range of $\mathrm{Na} / \mathrm{Cs}$ mole ratios $(50$ to 500,000$)$.

The following specific conclusions resulted from the study:

- For the multiple contact experiment, a maximum ${ }^{137} \mathrm{Cs}$ DF of 421 was obtained with the SL-644 material. This corresponds to a ${ }^{137} \mathrm{Cs}$ level of $0.46 \mathrm{Ci}$ m at $5 \underline{\mathrm{M} \mathrm{Na}}$, which is lower than the NRC Class A limit of $1 \mathrm{Ci} \mathrm{m}^{-3}$. The maximum DF for $\mathrm{Sr}$ of 239 was obtained using the IE-911 material. This corresponds to an effluent 
concentration of $6.7 \mathrm{E}-04 \mathrm{Ci} \mathrm{m}^{-3}$, which is significantly lower than the NRC Class A limit of $0.04 \mathrm{Ci} \mathrm{m}^{-3}$. These DFs are a general reflection of the $\lambda$ values and are not an indication of the DFs that could be obtained in a column type operation. For both cesium and strontium, it is likely that additional contacts with any material would have provided additional decontamination.

- For all of the ion exchange materials examined, the calculated cesium $\lambda$ values increase with $\mathrm{Na} / \mathrm{Cs}$ ratio (decreasing cesium concentration) and decrease with increasing sodium concentration. Cesium $\lambda$ values varied from 2 to $6.0 \mathrm{E}+04$ with the following order over most solution conditions: IE-910 $\approx$ IE-11 $>$ SL-644 $\approx$ R-F $>$ TIE-96 > CS-100. In general, the organic exchangers exhibited lower cesium $\lambda$ values than IE910 or IE-911. Since they will most likely be used in a regenerable column configuration, a high cesium $\lambda$ is not as important for the organic exchangers as it is for the inorganic exchangers. Material stability and the ease with which the exchangers can be eluted and regenerated are more important and were not addressed in this study.

- In general, there was agreement between the cesium $\lambda$ results obtained with the simulated and actual wastes. However, for all of the materials, the actual waste results were lower than those obtained in the simulant. At feed conditions $(5 \underline{\mathrm{M} \mathrm{Na}}$ and $\mathrm{Na} / \mathrm{Cs}=78,000$ ), the difference between the simulant and actual waste cesium $\lambda$ values were $-4 \%,-50 \%,-14 \%,-35 \%,-21 \%$, and $-24 \%$, for CS-100, R:F, SL-644, IE910, IE-911, and TIE-96, respectively.

- The CST sorbent (powdered IE-910 and engineered IE-911) demonstrated high affinity for cesium and strontium in the actual and simulated waste solutions. The cesium $\lambda$ of the IE-911 (38B) material was virtually identical to that of the IE-910 during the actual and simulant waste tests (at $5 \mathrm{M} \mathrm{Na}$ ) and only $20 \%$ to $30 \%$ lower at $0.2 \mathrm{M} \mathrm{Na}$ in the simulant. Evidently, fabrication into an engineered form did not severely impact the equilibrium cesium distribution.

- Comparison of cesium and strontium $\lambda$ values from batch contacts at different phase ratios do not indicate the presence of interfering components that might foul the exchanger surface or exchange sites.

- Based on the actual waste ICP results, the organic ion exchangers remove chromium (SL-644 > R-F > CS-100). In addition, zirconium was removed by all of the materials except IE-911, with the following order: NaTi $\approx$ TIE-96 >> SL-644 > R$\mathrm{F} \approx \mathrm{CS}-100>\mathrm{IE}-910$. These data suggest that future testing will be necessary to address the issue of significant metals uptake.

- All of the materials demonstrated an affinity for strontium with the NaTi providing the greatest removal followed by IE-911, IE-910, and TIE-96. The organic exchangers exhibited relatively low affinities and would not be useful for strontium removal. 
- For every ion exchange material, the strontium $\lambda$ results were much lower in the actual waste experiment than those obtained during the simulant tests. This is most likely due to reduced strontium levels in the simulant with respect to the actual waste and the presence of organic materials in the actual waste that were not present in the simulant. The exact nature of these organics is not known, but they are generally complexant materials that would react with the strontium to form neutral or anionic complexes, thereby reducing the extent to which the cation exchange takes place.

- Based on the simulant testing results, a 25 -fold dilution of the waste from $5 \underline{\mathrm{M}} \mathrm{Na}$ to $0.2 \underline{\mathrm{M}} \mathrm{Na}$ increases the CST cesium loading 12-14\%, doubles the loading on the TIE-96, and decreases the cesium loading $40-45 \%$ for the organic exchangers. The process implication is that for inorganic materials, the amount of exchanger required can be minimized by processing dilute streams (e.g., before evaporative concentration of the waste). Conversely, if organic exchangers are used, the number of load/elute cycles can be minimized by processing concentrated waste streams.

The actual waste results are summarized in Table S.1 at the initial feed conditions of $5.0 \mathrm{M} \mathrm{Na}$, $0.48 \underline{\mathrm{M} \mathrm{K}}, 23^{\circ} \mathrm{C}$, and a $\mathrm{Na} / \mathrm{Cs}$ mole ratio of 78,000 . The equilibrium data are given as $\mathrm{K}_{\mathrm{d}}$ (exchanger mass basis) and $\lambda$ values (exchanger volume basis) to illustrate the effect of the bed density on the apparent performance. The $\lambda$ value is useful for sizing ion exchange columns, and the $K_{d}$ value is pertinent for assessing the impact of converting the loaded materials into a final waste form.

Table S.1. Actual Waste Testing Results at Feed Conditions (5 $\underline{\mathrm{M}} \mathrm{Na}, 0.48 \underline{\mathrm{M}} \mathrm{K}$, and $\mathrm{Na} / \mathrm{Cs}=78,000$ )

\begin{tabular}{|c|c|c|c|c|c|c|c|}
\hline $\begin{array}{l}\text { Exchanger } \\
\text { Description }\end{array}$ & $\begin{array}{c}\text { Material } \\
\text { Composition }\end{array}$ & $\begin{array}{l}\text { Material } \\
\text { Producer }\end{array}$ & $\begin{array}{c}\text { Density } \\
\text { g mL }^{-1}\end{array}$ & $\begin{array}{l}\operatorname{Cs~K}_{d} \\
\mathrm{~mL} \mathrm{~g}^{-1}\end{array}$ & $\operatorname{Cs} \lambda$ & $\begin{array}{c}\operatorname{Sr~K}_{d} \\
\mathrm{~mL} \mathrm{~g}^{-1}\end{array}$ & $\operatorname{Sr} \lambda$ \\
\hline IONSIV $^{\circledR}$ IE-911 & Silicotitanate & UOP & 1.13 & 710 & 800 & 900 & 1000 \\
\hline IONSIV $^{\oplus}$ IE-910 & Silicotitanate & UOP & $0.77^{(b)}$ & 910 & 700 & 700 & 540 \\
\hline IONSIV ${ }^{\oplus}$ TIE-96 & Zeolite & UOP & 0.77 & 21 & 16 & 250 & 190 \\
\hline NaTi & Sodium titanate & Allied Signal & $0.58^{(b)}$ & $N A^{(\mathcal{C})}$ & NA & 2100 & 1200 \\
\hline SuperLig® 644 & $\begin{array}{l}\text { Polymeric } \\
\text { macrocycle }\end{array}$ & $\begin{array}{l}\text { IBC } \\
\text { Advanced } \\
\text { Technologies }\end{array}$ & $0.22^{(d)}$ & 500 & 110 & 90 & 20 \\
\hline R-F & $\begin{array}{l}\text { Resorcinol- } \\
\text { formaldehyde }\end{array}$ & $\begin{array}{l}\text { Boulder } \\
\text { Scientific }\end{array}$ & 0.30 & 220 & 65 & 60 & 18 \\
\hline Duolite ${ }^{\circ}$ CS-100 & $\begin{array}{l}\text { Phenol- } \\
\text { formaldehyde }\end{array}$ & Rohm \& Haas & 0.24 & 88 & 21 & 13 & 3 \\
\hline $\begin{array}{l}\text { (a) Ion exchange n } \\
\text { (b) Bulk powder d } \\
\text { (c) Not applicable } \\
\text { (d) Measured in N }\end{array}$ & $\begin{array}{l}\text { erial density mea } \\
\text { sity (dry weight b } \\
\text { rontium ion exch } \\
\text { AW waste simular }\end{array}$ & $\begin{array}{l}\text { Ired on a dry wei } \\
\text { sis). } \\
\text { ige material. }\end{array}$ & thasis in 2 & $\mathrm{NaOH}$ un & ss other & ise noted. & \\
\hline
\end{tabular}





\section{Acknowledgments}

Pacific Northwest National Laboratory (Northwest National Laboratory) is collaborating with universities, national laboratories, and industry to develop and test new materials for the pretreatment of nuclear wastes stored at Hanford. Much of the experimental work described in this report would not have been possible without the encouragement and resources provided by Dr. Teresa Fryberger, program manager of the Efficient Separations and Processing Cross-Cutting Program (ESP) and Dr. Ken Gasper, program manager of the Westinghouse Hanford Company (WHC) TWRS Pretreatment Program. Development of the SuperLig 644 (IBC Advanced Technologies, American Fork, UT) and sodium titanate (Allied Signal, Des Plaines, IL and Professor A. Clearfield, Texas A\&M) is coordinated under ESP at Northwest National Laboratory by L. A. Bray. Development of the crystalline silicotitanate (CST) powder (R.G. Dosch, Sandia National Laboratories (SNL) and Professor R.G. Anthony, Texas A\&M) is coordinated under ESP at SNL by N.E. Brown. The engineered CST (IONSIV ${ }^{\circledR}$ IE-911) is being developed by UOP, Des Plaines, IL under a Cooperative Research and Development Agreement (CRADA) with SNL. The resorcinol-formaldehyde resin (R-F) was developed by J.P. Bibler and R.M. Wallace at the Westinghouse Savannah River Company (WSRC) and is

produced by Boulder Scientific (Mead, CO). Funding for testing of the IE-911, ${ }^{100} \mathrm{Cs}$, and R-F materials in the actual and simulated Hanford tank wastes was provided by the TWRS Pretreatment Program. Technical peer review was provided by K.P. Brooks (Northwest National Laboratory). The authors wish to acknowledge the technical support of M.W. Goheen, L.R. Greenwood, K.A. Poeppel, R.T. Ratner, D.R. Sanders, R.T. Steele, K.L. Silvers, K.J. Smith, J.J. Wagner, and M.W. Urie (Northwest National Laboratory); M.J. Klem (WHC); and N.E. Brown and J.E. Miller (SNL). 



\section{Contents}

Abstract $\ldots \ldots \ldots \ldots \ldots \ldots \ldots \ldots \ldots \ldots \ldots \ldots \ldots \ldots$

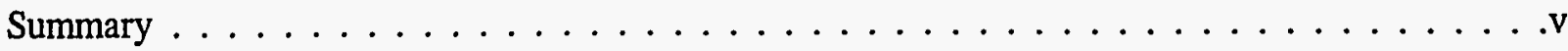

Acknowledgments $\ldots \ldots \ldots \ldots \ldots \ldots \ldots \ldots \ldots \ldots \ldots \ldots \ldots \ldots$

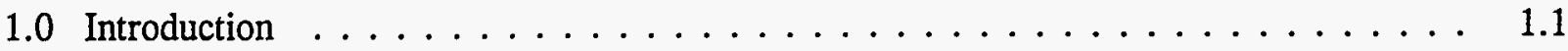

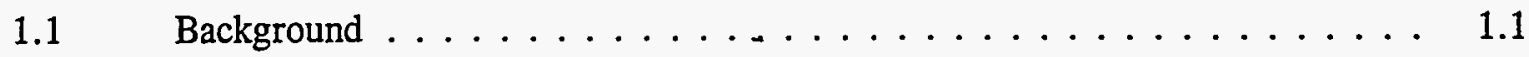

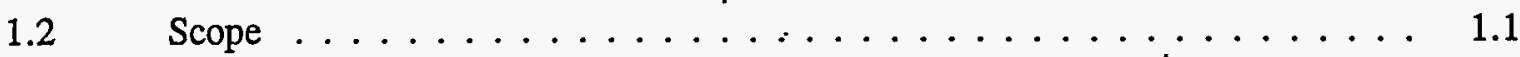

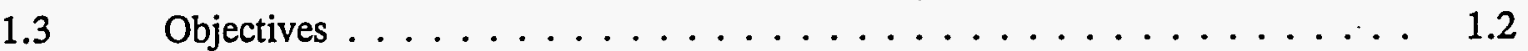

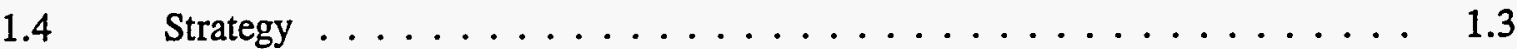

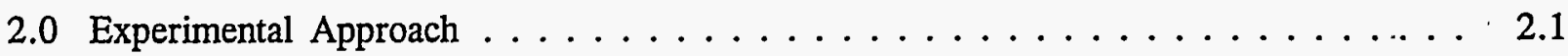

$2.1 \quad$ Material Selection and Preparation . . . . . . . . . . . 2.1

2.2 Waste Simulant Selection and Preparation . . . . . . . . . 2.3

$2.3 \quad$ Bátch Distribution Coefficient $\ldots \ldots \ldots \ldots \ldots \ldots \ldots \ldots \ldots$

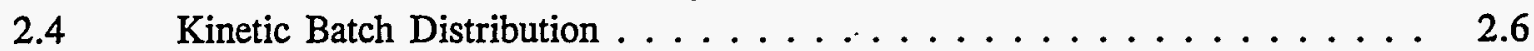

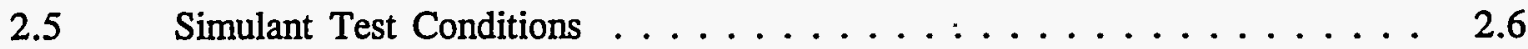

2.6 Actual Waste Test Configurations and Conditions $\ldots \ldots \ldots \ldots$

2.6.1 Cesium Addition Method . . . . . . . . . . . . 2.7

2.6.2 Multiple Contact (High DF) Method . . . . . . . . . 2.8

2.6.3 High Phase Ratio Method . . . . . . . . . . . . 2.8

$2.7 \quad$ Chemical and Radionuclide Analysis . . . . . . . . . . . 2.9

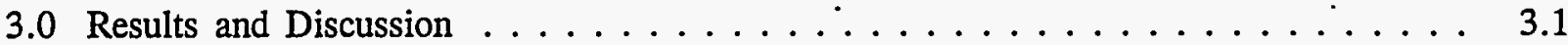

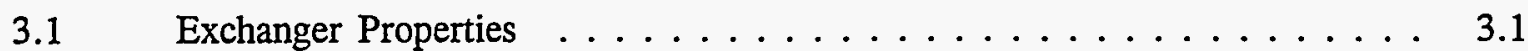

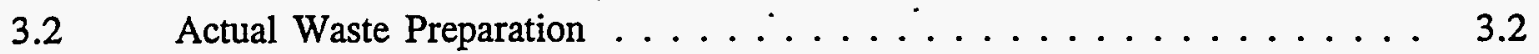


3.3 Time-Dependent Cesium Distribution in Simulated DSSF . . . . . . 3.5

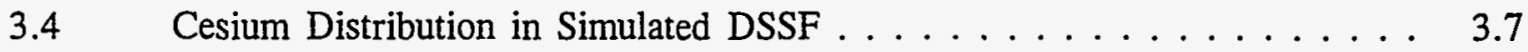

$3.5 \quad$ Cesium Distribution in Actual DSSF $\ldots \ldots \ldots \ldots \ldots \ldots \ldots \ldots \ldots$

3.6 Strontium Distribution in Actual and Simulated DSSF . . . . . . 3.16

$3.7 \quad$ Distribution of ICP Metals in Actual DSSF $\ldots \ldots \ldots \ldots \ldots$

$3.8 \quad$ Multiple Contact Distributions in Actual DSSF $\ldots \ldots \ldots \ldots \ldots \ldots$

3.8 .1 Cesium Distribution $\ldots \ldots \ldots \ldots \ldots \ldots \ldots \ldots$

3.8 .2 ICP Metals Distribution . . . . . . . . . . . . 3.21

$3.9 \quad$ High Phase Ratio Distributions in Actual DSSF $\ldots \ldots \ldots \ldots \ldots . \ldots . . \ldots$

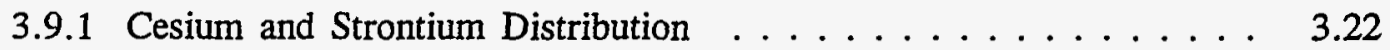

3.9 .2 ICP Metals Distribution . . . . . . . . . . . . . 3.22

$4.0 \quad$ Conclusions $\ldots \ldots \ldots \ldots \ldots \ldots \ldots \ldots \ldots \ldots \ldots \ldots \ldots \ldots$

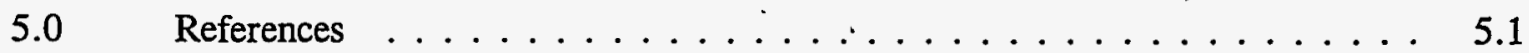

Appendix A - Test Instructions for DȘSF Waste Preparation $\ldots \ldots \ldots \ldots$ A.1

Appendix B - Cesium and Strontium $\lambda$ Values for the Simulant Experiments . . . B B.1

Appendix C - Cesium and Strontium $\lambda$ Values for the Actual Waste Experiments . . C.1

Appendix D - Chromium, Zirconium, and Strontium $\lambda$ Values for the Actual

Waste Experiments ................... D.1 


\section{Figures}

3.1 Kinetic Batch Distribution Cesium Uptake in Simulated 70\% 101-AW DSSF Composite at $5 \mathrm{M} \mathrm{Na}, 1.00 \mathrm{E}-04 \underline{\mathrm{M}} \mathrm{Cs}$, and $25^{\circ} \mathrm{C} \ldots \ldots \ldots \ldots \ldots \ldots$

3.2 Cesium $\lambda$ Values for CS-100 in Simulated 70\% 101-AW DSSF Composite at $25^{\circ} \mathrm{C} \ldots \ldots$

3.3 Cesium $\lambda$ Values for TIE-96 in Simulated 70\% 101-AW DSSF Composite at $25^{\circ} \mathrm{C} \ldots \ldots$

3.4 Cesium $\lambda$ Values for R-F in Simulated $70 \%$ 101-AW DSSF Composite at $25^{\circ} \mathrm{C} \ldots \ldots .8$

3.5 Cesium $\lambda$ Values for SL-644 in Simulated 70\% 101-AW DSSF Composite at $25^{\circ} \mathrm{C} \ldots \ldots 3.9$

3.6 Cesium $\lambda$ Values for IE-910 in Simulated 70\% 101-AW DSSF Composite at $25^{\circ} \mathrm{C} \ldots \ldots .9$

3.7 Cesium $\lambda$ Values for IE-911 (38b) in Simulated 70\% 101-AW DSSF

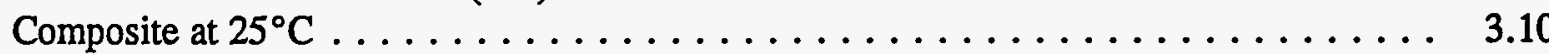

3.8 Cesium $\lambda$ Values for IE-911 (08) in Simulated 70\% 101-AW DSSF Composite at $25^{\circ} \mathrm{C}$

3.9 Comparison of Cesium $\lambda$ Values for Powdered (IE-910) and Engineered (IE-911[38B]) Forms of the Crystalline Silico-Titanate Sorbent Material in Simulated 70\% 101-AW DSSF Composite at $25^{\circ} \mathrm{C}$

3.10 Comparison of Cesium $\lambda$ Values for Powdered (IE-910) and Engineered (IE-911[08]) Forms of the Crystalline Silico-Titanate Sorbent Material in Simulated 70\% 101-AW DSSF Composite at $25^{\circ} \mathrm{C}$

3.11 Comparison of Cesium $\lambda$ Values for Cesium-Selective Materials as a Function of Sodium Concentration in Simulated 70\% 101-AW DSSF Composite at $25^{\circ} \mathrm{C}$ and an Equilibrium Na/Cs Ratio of $1.00 \mathrm{E}+04$

3.12 Comparison of Cesium $\lambda$ Values for Cesium-Selective Materials as a Function of Sodium Concentration in Simulated 70\% 101-AW DSSF Composite at $25^{\circ} \mathrm{C}$ and an Equilibrium $\mathrm{Na} / \mathrm{Cs}$ Ratio of 1.00E +06

3.13 Comparison of Cesium $\lambda$ Values for Cesium Selective Materials in Simulated $70 \%$ 101-AW DSSF Composite at $5 \mathrm{M} \mathrm{Na}$ and $25^{\circ} \mathrm{C} \ldots \ldots \ldots \ldots$

3.14 Comparison of Cesium $\lambda$ Values for Cesium Selective Materials in Actual $70 \%$ 101-AW DSSF Composite at $5 \mathrm{M}$ Na and $25^{\circ} \mathrm{C} \ldots \ldots \ldots \ldots \ldots$

3.15 Comparison of Cesium $\lambda$ Values for Actual and Simulated 70\% 101-AW DSSF Composite at $5 \underline{\mathrm{M} \mathrm{Na}}$ and $25^{\circ} \mathrm{C}$ 
3.16 Comparison of Cesium $\lambda$ Values for Actual and Simulated 70\% 101-AW DSSF

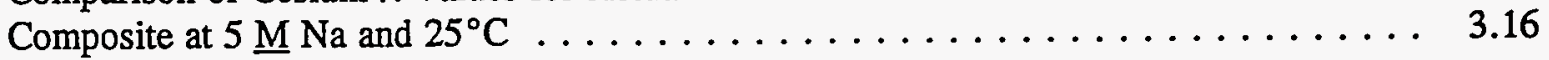

3.17 Strontium $\lambda$ Values in Actual 70\% 101-AW DSSF Composite at $5 \underline{\mathrm{M}} \mathrm{Na}$ and $25^{\circ} \mathrm{C} \ldots$ 


\section{Tables}

S.1 Actual Waste Testing Results at Feed Conditio $\ldots \ldots \ldots \ldots$ vii

2.1 Selected Properties of Cesium and Strontium Selective Materials. . . . . . . . . 2.1

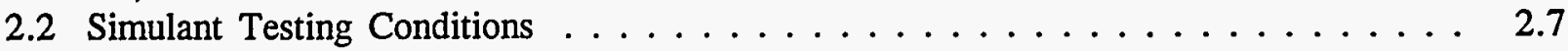

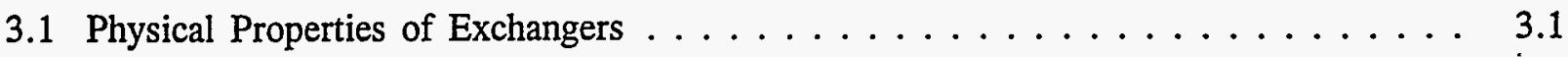

3.2 Comparison of DSSF Actual and Simulant Waste Solutions $\ldots \ldots \ldots . \ldots$

3.3 Additional Characterization of Actual DSSF Composite . . . . . . . . . 3.5

3.4 Strontium Distribution Results in Simulated 70\% 101-AW DSSF Waste $\ldots \ldots . . . \quad 3.17$

3.5 Comparison of Strontium $\lambda$ Values in Actual and Simulant 70\% 101-AW

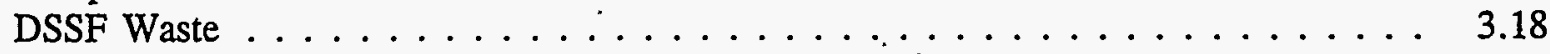

3.6 Selected Metal Distribution Results in Actual 70\% 101-AW DSSF Waste . . . . . 3.19

3.7 Cumulative Cesium and Strontium Decontamination Factors in Actual

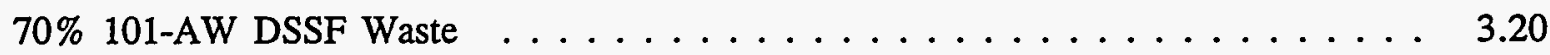

3.8 Metal Distribution Results from Second Contact in Actual 70\% 101-AW DSSF Waste 3.21

3.9 Comparison of Cesium and Strontium Distribution Results at Two Phase Ratios _ . 3.22

3.10 High Phase Ratio Metal Distribution Results in Actual 70\% 101-AW DSSF Waste 3.23 
: 


\subsection{Introduction}

\subsection{Background}

The contents of Hanford's 177 double- and single-shell waste tanks include a mixture of sludge, salt cake, and alkaline supernatant liquid. In many of these tanks, the supernate consists of concentrated aqueous solutions of sodium nitrate/nitrite salts with smaller quantities of hydroxide, aluminum, potassium, carbonate, sulfate, and phosphate. The salt cake, generated by extensive evaporation of aqueous solution, consists primarily of dried sodium salts. The bulk of the water soluble radionuclides, such as ${ }^{137} \mathrm{Cs}$, are contained in the interstitial liquid, salt cake, and supernatant solutions. The insoluble sludge fraction consists of metal oxides/hydroxides and contains the bulk of the ${ }^{90} \mathrm{Sr}$ and many of the transuranic radionuclides (TRU).

Although the pretreatment and disposal strategy is still being defined, one of the first steps in most pretreatment scenarios will be a separation of the supernatant and dissolved salt cake from the sludges. It is envisioned that cesium will be removed from the aqueous solutions using an ion exchange process, and the decontaminated solutions will be immobilized as a low-activity waste. The specific cesium decontamination requirements will depend on waste composition and the disposal requirements for the - low-activity waste. The separated cesium will be concentrated and vitrified with the high-level waste sludge for disposal in the high-level waste repository.

\subsection{Scope}

A number of organic and inorganic exchangers are being developed and evaluated for removing cesium from Hanford tank wastes. The exchangers of interest that are investigated in this work include

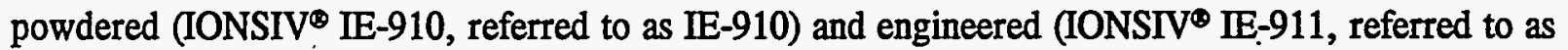
IE-911) forms of the crystalline silico-titanate (CST) inorganic sorbent developed by Sandia National Laboratories (SNL)/Texas A\&M and prepared by UOP; a phenol-formaldehyde (CS-100) resin developed by Rohm and Haas; a resorcinol-formaldehyde (R-F) polymer developed at the Westinghouse Savannah River Company (WSRC) and produced by Boulder Scientific; an inorganic zeolite exchanger produced by UOP (IONSIV TIE-96, referred to as TIE-96); an inorganic sodium titanate produced by Allied Signal/Texas A\&M (NaTi); and a macrocyclic organic resin developed and produced by IBC Advanced Technologies (SuperLig $\$$ 644, referred to as SL-644). Several of these materials are still under development and may not be in the optimal form.

The testing described in this report is a joint effort with the project "Develop and Test Sorbents" which is funded by the Efficient Separations Cross-Cutting Program (EM-50) and the "Batch Testing of Crystalline Silico-Titanates" subtask, which is part of the Pacific Northwest National Laboratory (Northwest National Laboratory) TWRS Pretreatment Technology Development Project (funded by EM-30). Funding for the investigation of the IE-910, TIE-96, NaTi, and SL-644 is provided by the EM-50 program, and funding for the testing of the IE-911, CS-100, and R-F is provided by the EM-30 
program. These two efforts have been combined in order to have a common testing protocol, share actual waste samples, share data, and facilitate the transfer of technology from the Efficient Separations Program to the implementing organization (EM-30). This common testing will allow a side-by-side comparison of all of the exchangers under investigation.

The work described in this report involves the direct comparison of the ion exchange materials for the pretreatment of actual and simulated Hanford tank waste. Data on the performance of all of the exchangers with simulated and actual double shell slurry feed (DSSF) is included. The DSSF waste is a mixture of the supernate from tanks 101-AW (70\%), 106-AP (20\%), and 102-AP (10\%).

The comparative parameters include radionuclide removal efficiency under a variety of conditions and material properties (e.g., bed density and percent removable water). Cesium and strontium distribution $\left(K_{d}\right)$, lambda $\left.\lambda=K_{d} \times \rho_{b}\right)$, and decontamination factors (DF) are compared as a function of exchanger contact duration, solution composition ( $\mathrm{Na}$ and cesium concentration), exchanger/waste phase ratio, and multiple sequential contacts.

\subsection{Objectives}

The overall objective of the cesium ion exchange task is 1) to evaluate available materials for the ion exchange recovery of cesium and strontium from alkaline wastes, 2) to determine the loading and elution efficiency of these processes, 3 ) to determine the physical life cycle (including radiation and chemical stability) of these materials, and 4) to determine if basic ion exchange data can be applied to a broad range of tank wastes. The intent is to provide the technology to produce a low-level waste (LLW) effluent with radioactivity suitable for treatment in the LLW glass vitrification facility.

Specific experimental objectives of the batch testing work described in this report are to:

- obtain information on the equilibrium behavior of the ion exchangers under consideration

- investigate the achievable decontamination factor for cesium and other radionuclides

- verify the results of simulant testing by conducting tests with actual wastes

- investigate the behavior of waste components that may interfere with the ion exchange process, either by surface fouling or site-specific competition

- investigate waste/exchanger chemistry (i.e., dissolution, precipitation, etc.) 


\subsection{Strategy}

The objective of the batch contact testing is to obtain screening information concerning the suitability of exchangers for specific treatment applications. The basic experimental operation involves batch contacts between the exchangers and the simulant and actual waste solutions. The advantage of batch testing relative to column testing is that a large amount of equilibrium data (i.e., $K_{d}$ or $\lambda$ ) can be obtained with relatively small amounts of waste at reduced unit cost (i.e., cost per data point). Simulant testing was conducted at several dilutions $([\mathrm{Na}]=0.2,1.0,3.0$, 5.0 , and $7.0 \mathrm{M})$ and cesium concentrations $(\mathrm{Na} / \mathrm{Cs}=50,500,5000,50000$, and 500,000$)$ to develop procedures for contacting the actual waste and to provide additional equilibrium data over a large number of experimental conditions. Trace amounts of ${ }^{137} \mathrm{Cs}$ and ${ }^{85} \mathrm{Sr}$ were used for analytical purposes.

During the actual waste testing, three separate contacting methods were used to provide information over a wide range of supernate:exchanger phase ratios and are discussed below.

Cesium Addition Method - Four separate contacts involving $10 \mathrm{~mL}$ of waste and $0.067 \mathrm{~g}$ of . exchanger were conducted with the actual 70\% 101-AW double-shell slurry feed (DSSF) composite waste. In three of these contacts, different amounts of nonradioactive cesium were added into the actual waste supernate to provide equilibrium data at four different cesium concentrations. The amounts were chosen so that the equilibrium $\mathrm{Na} / \mathrm{Cs}$ ratios of the tests bounded the $\mathrm{Na} / \mathrm{Cs}$ ratio of the actual $70 \%$ 101-AW DSSF waste composite.

High DF Method - The supernate from the previous method (without additional cesium) was contacted with an additional $0.5 \mathrm{~g}$. of exchanger in order to investigate the achievable decontamination factor. The large amount of exchanger was necessary to efficiently remove most of the ${ }^{137} \mathrm{Cs}$.

High Phase Ratio Method - In order to adequately investigate the effect that interfering components have on cesium $K_{d}$, the supernate:exchanger phase ratio was increased to match the expected distribution coefficient. The high phase ratio provides a large amount of interfering components relative to the number of exchanger sites and increases the impact of these components on equilibrium behavior. 


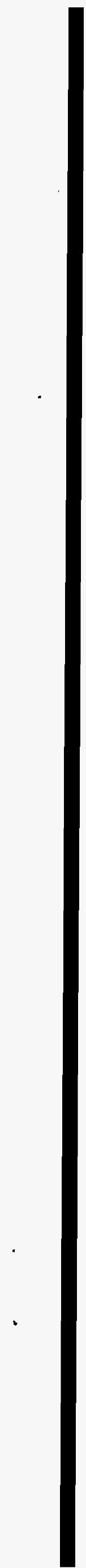




\subsection{Experimental Approach}

This section contains a description of the exchanger materials, waste solutions, and experimental procedures that were used.

\subsection{Material Selection and Preparation}

A listing of the exchangers under consideration along with selected manufacturing information is displayed in Table 2.1. Several of these materials are still under development and may not be in the optimal form. The SuperLig ${ }^{\circledR 644}$ polymer resin is the latest version of the covalently bound SuperLig ${ }^{\circledR}$ macrocycle family of sequestering ligands from IBC Advanced Technologies (American Fork, UT) and has been shown to be highly selective for cesium, even in the presence of excess sodium or potassium (Brown et al. 1995b). The inorganic sodium titanate (NaTi) is a powder. produced by Allied Signal (Des Plaines, IL) in collaboration with Professor A. Clearfield at Texas A\&M, primarily for strontium removal.

CS-100 and resorcinol-formaldehyde (R-F) are two organic ion exchange resins that are commercially available and under consideration for cesium removal from Hanford tank wastes (Brown et al. 1995a; Brown et al. 1995b; Brown et al. 1995c; Eager et al. 1994; Penwell et al. 1994). ${ }^{\text {(a) }}$ CS-100

Table 2.1. Selected Properties of Cesium and Strontium Selective Materials

\begin{tabular}{||l|c|l|l|c||}
\hline \multicolumn{1}{|c|}{ Material } & ID & \multicolumn{1}{|c|}{ Batch Number } & \multicolumn{1}{c|}{$\begin{array}{c}\text { Date of } \\
\text { Manufacture }\end{array}$} & $\begin{array}{c}\text { Particle } \\
\text { Size (Mesh) }\end{array}$ \\
\hline \hline Duolite CS-100 & CS & $\begin{array}{l}6-8144 \text { Lot 2- } \\
850001\end{array}$ & Nov 1991 & $20-50$ \\
\hline IONSIV TIE-96 & ZE & $975791000012-A$ & Sept 1995 & $20-50$ \\
\hline $\begin{array}{l}\text { Resorcinol- } \\
\text { Formaldehyde }\end{array}$ & RF & BSC-187-210 & Aug 1991 & $40-70$ \\
\hline SuperLig ${ }^{\text {644 }}$ & SL & $10-S M-171$ & Nov 1994 & $25-45$ \\
\hline IONSIV IE-910 & CP & 993794040002 & Sept 1994 & $<400$ \\
\hline IONSIV ${ }^{\circledR}$ IE-911 & CE & $07398-38 B$ & Jun 1995 & $40-70$ \\
\hline IONSIV IE-911 & & $8671-08$ & Jun 1995 & $20-50$ \\
\hline Sodium Titanate & TI & $-8104-170$ & May 1994 & $<400$ \\
\hline
\end{tabular}

(a) Gallagher, S. A. 1986. Report of Current NCAW Ion Exchange Laboratory Data. Internal Letter \#65453-86-088, Rockwell International, Richland, Washington. 
is a granular (20 to 50 mesh) phenol-formaldehyde condensate polymer ion exchange resin that is commercially available from Rohm \& Haas. R-F, originally developed by J. P. Bibler and R. M. Wallace at WSRC and currently produced by Boulder Scientific (Mead, CO), has been shown to exhibit a much greater loading for cesium and selectivity over sodium or potassium than the CS100 resin (Bibler et al. 1989; Bibler 1991; Bibler 1994; Bray et al. 1990; Kurath et al. 1994).

IE-96 is a high-capacity aluminosilicate zeolite produced by UOP (Des Plaines, IL) with relatively little selectivity for cesium over other alkali metals. TIE-96 is a modified version of the IE-96 that is capable of removing strontium and plutonium from alkaline solutions in addition to cesium (Bray and Hara 1991, Bray et al. 1984).

Also produced by UOP on an experimental basis, IE-910 and IE-911 are the powdered and engineered forms of the CSTs, respectively. The engineered CST (IONSIV ${ }^{\circledR}$ IE-911) is being developed by UOP (Des Plaines, IL) under a Cooperative Research and Development Agreement (CRADA) with SNL. The CSTs were originally developed in a powdered form by R.G. Dosch at SNL and Professor R.G. Anthony at Texas A\&M (Anthony et al. 1994, 1993; Dosch et al. 1993; Klavetter et al. 1994; Zheng et al. 1995). Two batches of engineered IE-911 ( -08 and $-38 \mathrm{~B})$ were investigated in these experiments. UOP has further developed the IE-911, with improved kinetics and samples expected to be available in January 1996.

Because of different manufacturing processes, each material does not contain the same counter ion when received from the manufacturer. CS-100 and SuperLig ${ }^{\circledR} 644$ are in the $\mathrm{H}^{+}$-form, R-F is in the $\mathrm{K}^{+}$-form, and TIE-96, IE-910, IE-911, and NaTiA are likely in the $\mathrm{Na}$-form. It is possible that due to the variation in counter ion form and material capacity, the equilibrium composition of the waste could be altered by the ion exchange process. For example, as solution-phase cesium exchanges with $\mathrm{K}^{+}$in the R-F resin, the concentration of the $\mathrm{K}$ in solution must concurrently increase. In most cases, the quantity of solid material, and hence counter ion, is such that this increase is insignificant. In the worst case, assuming a total capacity of $6 \mathrm{meq} \mathrm{g}^{-1}$ for a high capacity material (e.g., R-F), a phase ratio of $150(0.067 \mathrm{~g}$ and $10 \mathrm{~mL}$ solution), and a potassium concentration of $0.48 \underline{\mathrm{M}}$, one can calculate less than a $10 \%$ change in the equilibrium of $\mathrm{K}^{+}$level if all of the $\mathrm{K}^{+}$were exchanged. Under the conditions tested, the majority of the material capacity is utilized by sodium exchange. A similar argument can be made for the $\mathrm{H}^{+}$-form exchangers. In the current experimental solution, these effects can be deemed insignificant due to the high potassium and free hydroxide levels of the actual and simulated 70\% 101-AW DSSF simulant waste.

All materials were used "as received" without additional processing. However, the $K_{d}$ data (Section 2.3) have been mass corrected to account for the fraction of easily removed water using the F-Factor. Approximately $0.5 \mathrm{~g}$ of each material was weighed before and after drying at $105^{\circ} \mathrm{C}$ for 24 hours. In order to ensure that a constant weight had been achieved, the materials were dried for a second 24 hour period and weighed again. 
In an attempt to compare the cesium uptake for each material on a volume basis, the bed density was determined in $2 \mathrm{M} \mathrm{NaOH}$. Each material was accurately weighed by difference into a 100-mL graduated cylinder containing $2 \mathrm{M} \mathrm{NaOH}$. The cylinders were tapped lightly and allowed to settle for approximately 24 hours. This provides a uniform basis for determining the bed density of each material. Many of the organic materials shrink and swell depending on the solution $\mathrm{pH}$. The bed density in other waste solutions may be significantly different than in $2 \underline{\mathrm{M}} \mathrm{NaH}$.

\subsection{Waste Simulant Selection and Preparation}

The primary wastes requiring cesium treatment at Hanford are neutralized current acid waste (NCAW), DSSF, complexant concentrate (CC) waste, salt cake, and sludge wash solutions. Each of these major waste types contains a unique characteristic that influences cesium ion exchange. The NCAW contains a relatively high amount of cesium $(\mathrm{Na} / \mathrm{Cs}$ mole ratio of 10,000$)$, with only a modest amount of potassium $(\mathrm{Na} / \mathrm{K} \approx 200)$. This waste has the greatest cesium decontamination factor (DF) .requirements and will provide the greatest cesium concentrations during processing. The DSSF contains a relatively large amount of potassium $(\mathrm{Na} / \mathrm{K}$ mole ratio as low as 10$)$, which is known to interfere with cesium ion exchange via the competing cation effect. The $\mathrm{CC}$ waste contains relatively large amounts of organic complexants, which are attendant chemical and radiolytic degradation products. These organics are not expected to interfere directly with the cesium ion exchange process although the expected large variety of constituents presents an uncertainty with respect to fouling of the exchangers. The dissolved salt cake and sludge wash solutions represent the bulk of the waste volume expected to generally require cesium removal. The sodium to cesium ratio is expected generally to be high (i.e., $>250,000$ ) and the DF requirements correspondingly low.

The simulant chosen for the testing described in this report models an actual DSSF waste composite. The specific composition and method of preparation are displayed in Appendix A and was used because a sample of actual waste with this composition was available. The actual waste sample does not necessarily represent a distinctive or characteristic waste, but rather is a composite of several DSSF tanks (70\% 101-AW, 20\% 106-AP, and 10\% 102-AP on a volume basis). This waste will be referred to as $70 \%$ 101-AW DSSF composite simulant to distinguish it from other DSSF compositions. The simulants were formulated to mimic the cesium ion exchange properties .of the actual waste and were prepared from a set of concentrated stock solutions with variable amounts of cesium and diluted with water-to-sodium concentrations of $0.2,1.0,3.0$, and $5.0 \underline{\mathrm{M}}$. The 70\% 101-AW DSSF -simulant at 7.0 $\underline{\mathrm{M}} \mathrm{Na}$ was prepared separately and did not require dilution. The method provides an easy method of preparing a wide variety of tank compositions for cesium ion exchange testing. In effect, the solutions predict variable dilutions or evaporator concentrates of a single waste stream. The approach is designed to provide useful process engineering data in the absence of precise ion exchange feed specifications. A similar approach has been taken previously for testing with CC and NCAW simulant (Bray et al. 1993, Kurath et al. 1994). Since the dilutions were prepared with water, the relative abundances of all of the 
species except cesium remain constant (i.e., for the 70\% 101-AW DSSF simulant $\mathrm{Na} / \mathrm{K}=10.5$ and $\mathrm{Na} / \mathrm{Al}=10.1$ ). However, the free hydroxide concentration and solution $\mathrm{pH}$ is not constant during dilution (theoretical $\mathrm{pH}=12.9$ and 13.6 at 0.2 and $1.0 \underline{\mathrm{M}} \mathrm{Na}$, respectively).

Trace amounts of ${ }^{137} \mathrm{Cs}$ or ${ }^{85} \mathrm{Sr}$ were added to the simulants for analytical purposes. The ${ }^{137} \mathrm{Cs}$

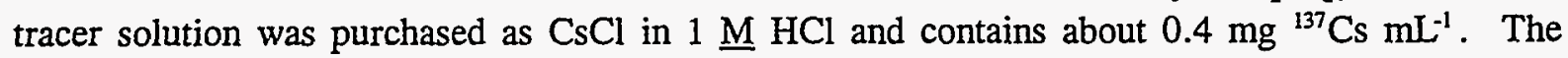
radiochemical activity of the "as received" material is usually $12 \mathrm{mCi} \mathrm{mL}^{-1}$ or $440 \mathrm{MBq} \mathrm{mL}^{1}$. For the sodium iodide well crystal radiochemical detector used in the laboratory, approximately $1 \mu \mathrm{L}$ $(12 \mu \mathrm{Ci})$ of the stock tracer is used per liter of feed. Similar trace amounts of ${ }^{85} \mathrm{Sr}$ were added to selected solutions to facilitate strontium analyses for testing of NaTi.

\subsection{Batch Distribution Coefficient}

The batch distribution coefficient $\left(\mathrm{K}_{\mathrm{d}}\right)$ is an equilibrium measure of the overall ability of the solid phase ion exchange material to remove an ion from solution under the particular experimental conditions that exist during the contact. The batch $\mathrm{K}_{\mathrm{d}}$ is an indicator of the selectivity, capacity, and affinity of an ion for the ion exchange material in the presence of a complex matrix of competing ions. The addition of a small quantity of ion exchange material into a small volume of supernatant solution is an extremely rapid and cost effective method for comparing a wide variety of such materials. However, this method does not normally provide information about ion exchange kinetics but is useful for measuring ion exchange under the particular conditions of the test. Accurate comparison of $\mathrm{K}_{\mathrm{d}}$ results requires identical experimental conditions (volume:mass ratio, equilibrium solution composition, material pretreatment, temperature, etc.) because all of these factors are known to affect $\mathrm{K}_{\mathrm{d}}$.

In the batch $K_{d}$ tests, a known quantity of ion exchange material is placed in contact with a known volume of waste. The material is allowed to contact the solution at constant temperature for sufficient time to reach equilibrium, after which the solid ion exchange material and liquid supernate are separated. The concentration of the species of interest is determined in the solution and in the solid phase. In practice it is easier to measure the concentration of the particular ion of interest in the solution instead of in the solid. Therefore, the equation for the determination of the batch distribution can be simplified by determining the concentration of the analyte before and after contact and calculating the quantity of analyte on the ion exchanger by difference (Equation 1).

$$
K_{d}=\frac{\left(C_{0}-C_{1}\right)}{C_{1}} * \frac{V}{M * F}
$$

where $C_{0}$ is the initial counts of the ion of interest in the feed solution before contact, $C_{1}$ is the counts after contact, $V$ is the solution volume, $M$ is the exchanger mass and, $F$ is the mass of dry ion exchanger divided by the mass of wet exchanger (F-factor). 
The column distribution ratio $\lambda$, is obtained by multiplying $K_{d}$ by the exchanger bed density, $\infty$ ( $\mathrm{g}$ of resin per $\mathrm{mL}$ of resin in solution) as shown in Equation 2.

$$
\lambda=\mathrm{K}_{\mathrm{d}} * \mathrm{P}_{\mathrm{b}}
$$

The lambda value provides a method of comparing the ion exchange performance of a wide variety of materials on a volume basis. Comparison of materials on a volume basis provides the process engineer an estimate of the cesium loading with respect to the column size required. However, the bed density of each material is highly variable depending upon solution conditions, column size, and loading methods and has a large effect on the cesium loading per material volume (lambda). Other methods of comparison (e.g., mass, cost, cycles, effluent composition, waste generation, ease of use, etc.) also may be important, but have not been attempted in this study. In particular, use of certain materials in a column may not be possible (e.g., finely powdered solids) and comparison on a mass basis may be more meaningful. Such comparisons are better suited for engineering trade studies.

The experimental equipment required to complete the batch $\mathrm{K}_{d}$ determinations included an analytical balance, a constant temperature water bath, an oven for F-Factor determinations, a variable speed shaker table, $20-\mathrm{mL}$ scintillation vials, $0.2 \mu \mathrm{m}$ syringe filters, the appropriate ion exchanger, and simulant solutions. Samples were placed into a controlled temperature environment at $25^{\circ} \mathrm{C}$ and agitated with either a "ping-pong" type shaker table at approximately $2 \mathrm{~Hz}$ or a Maxi Mix III orbital shaker at 400 to $600 \mathrm{~Hz}$. After reaching the appropriate contact duration (normally 72 hours), the samples were removed from the shaker table and the solids were separated from the liquid by filtration through a $0.2 \mu \mathrm{m}$ syringe filter. The filtered solutions were analyzed for ${ }^{137} \mathrm{Cs}$ or ${ }^{85} \mathrm{Sr}$ by gamma counting using a NaI crystal. Each $3 \mathrm{~mL}$ sample was counted for 20 minutes. Control blanks were prepared with no sorbent material added and were treated in the same manner as the samples.

In general, the uncertainties associated with the $\lambda$ and $\mathrm{K}_{\mathrm{d}}$ values are estimated to be less than $10 \%$. Calculation of standard deviations ( $\sigma$ ) for each pair of $\lambda$ values (duplicate samples) shows that $\sigma$ is generally less than $10 \%$ of the $\lambda$ value and usually less than $5 \%$. Some pairs of $\lambda$ values. exhibit remarkable similarity, being the same value to 4 digits.

The values of $K_{d}$ and $\lambda$ will exhibit the greatest uncertainty at very high and very low values. In the former case, the concentration $C_{1}$ in Equation 1 begins to approach zero and the analytical uncertainty of this value increases. For example, the error associated with each individual ICP analytical result is expected to exceed $15 \%$ within ten times the detection limit. During the actual waste test, the radioanalytical uncertainty was $5 \%$ for ${ }^{137} \mathrm{Cs}$ and from $3 \%$ to $12 \%$ for $\mathrm{Sr}$. In the latter case where only small amounts of the radionuclide are removed and the $K_{d}$ and $\lambda$ values are low, the small difference in concentration $\left(C_{0}-C_{1}\right)$ becomes a significant source of error. 
Another probable source of uncertainty in $\lambda$ is that associated with each material's dry bed density. Solution composition, sample size/dimensions, and time will all affect the apparent bed density. In addition, the organic exchangers exhibit variations from other reported bed densities of as much as $50 \%$. This does not affect the determination of $K_{d}$ but would affect the cesium $\lambda$ values determined using Equation 2.

\subsection{Kinetic Batch Distribution}

Due to the extensive variety of ion exchange and sorbent materials used in the current experiment, the extent of cesium uptake as a function of time was investigated in order to ensure equilibrium could be reached for every material tested. The materials exhibit a wide variability of particle sizes ranging from submicron powders to macro porous polymers. The different particle sizes and material structures affect the diffusion rates in the particle and can greatly influence the length of time required to achieve equilibrium.

The objective of this method is to demonstrate that adequate contact time was allowed for equilibrium to be attained. The general experimental conditions were the same as described in Section 2.3, except that the contact time was varied from $1 \mathrm{~min}$ to 120 hours. Approximately $0.067 \mathrm{~g}$ of each material was contacted with $10 \mathrm{~mL}$ of $70 \% 101-\mathrm{AW}$ DSSF simulant (5 $\mathrm{M} \mathrm{Na}$, $1.00 \mathrm{E}-04 \underline{\mathrm{M}} \mathrm{Cs}$, initial $\mathrm{Na} / \mathrm{Cs}=5.00 \mathrm{E}+04)$. A separate sample was prepared for each material at each contact time (variable from $1 . \mathrm{min}$. to 120 hours). The 1-min. samples were swirled manually in an attempt to mimic the action of the shaker table. All other samples were placed into a controlled temperature environment at $25^{\circ} \mathrm{C}$ and agitated with a "ping-pong" type shaker table at approximately $2 \mathrm{~Hz}$. Immediately after reaching the appropriate contact duration, the samples were removed from the shaker table, and the solids were separated from the liquid by filtration through a $0.2-\mu \mathrm{m}$ syringe filter. The filtered solutions were analyzed for ${ }^{137} \mathrm{Cs}$ by gamma counting. Control blanks were prepared with no sorbent material added and were treated in the same manner as the samples. The cesium $\mathrm{K}_{\mathrm{d}}$ and $\lambda$ values were determined using Equation 1. No attempt was made to ensure diffusion rate limited ion exchange (i.e., maximum mixing for the greatest mass transfer) and hence, the data cannot be used to model the kinetics of ion exchange.

\subsection{Simulant Test Conditions}

In order to obtain a wide range of equilibrium data and estimate exchanger performance with the actual DSSF composite, a series of batch distribution tests were completed using the 70\% 101AW DSSF simulant waste at the conditions shown in Table 2.2. 
Table 2.2. Simulant Testing Conditions

\begin{tabular}{||l|l||}
\hline \multicolumn{1}{|c|}{ Experimental Parameter } & \multicolumn{1}{c|}{ Experimental Conditions } \\
\hline \hline Exchangers: & $\begin{array}{l}\text { SL-644, R-F, CS-100, NaTi, } \\
\text { IE-910, IE-911, TIE-96 }\end{array}$ \\
\hline Waste simulant: & $70 \% 101-\mathrm{AW}$ DSSF simulant \\
\hline Sodium concentration: & $\begin{array}{l}0.2,1,3,5 \mathrm{M} \mathrm{Na} \\
(7 \mathrm{M}, \mathrm{IE}-911 \text { only) }\end{array}$ \\
\hline Initial Na/Cs ratio: & $50,500,5000,50,000,500,000$ \\
\hline Waste Volume: & $10 \mathrm{~mL}$ \\
\hline Exchanger mass: & $\mathrm{ca} .0 .067 \mathrm{~g}$ \\
\hline Contact time/temperature: & $72 \mathrm{hrs}, 25^{\circ} \mathrm{C}$ \\
\hline Tracers: & ${ }^{137} \mathrm{Cs},{ }^{85} \mathrm{Sr}$ \\
\hline
\end{tabular}

\subsection{Actual Waste Test Configurations and Conditions}

Three separate types of contacts were performed with the actual waste to provide a range of phase ratios (solution:exchanger) and to minimize the amount of actual waste required. These methods were the cesium addition method, the high DF method, and the high phase ratio method.

\subsubsection{Cesium Addition Method}

For the actual waste testing, the actual waste solution (previously diluted to $5 \underline{\mathrm{M}} \mathrm{Na}$ total) was subdivided into four stock solutions. Solid nonradioactive cesium nitrate was added to three of these solutions bringing the total concentration to approximately 5.00E-02, 5.00E-03, and 5.00E-04 $\underline{M}$ Cs. No cesium was added to the fourth solution, and its concentration remained at approximately $6.33 \mathrm{E}-05 \underline{\mathrm{M}} \mathrm{Cs} . \mathrm{A}^{85} \mathrm{Sr}$ spike $\left(8.6 \mu \mathrm{Ci} \mathrm{mL}^{1}\right)$ was added for analytical purposes.

The reason for performing the contacts with several wastes each with different starting cesium levels is to effectively bracket the initial waste feed (6.33E-05 $\mathrm{M} \mathrm{Cs)}$ with the final equilibrium cesium concentrations of the four solutions. Since by definition all cesium-selective materials will remove cesium from solution and decrease the equilibrium concentration, additional cesium must be . added to the initial solution to compensate for this removal. The result will be a method to predict the column loading for each material using actual waste without performing a large-scale column experiment.

The batch contacts with the cesium addition method were conducted in the same manner as were the simulant tests. Each contact involved $10 \mathrm{~mL}$ of solution with about $0.067 \mathrm{~g}$ of exchanger and was agitated with an orbital shaker at about $400 \mathrm{rpm}$. This motion was sufficiently gentle that 
the exchangers were not degraded (i.e., reduced to fines). The contact time was 72 hours at the ambient temperature of the hot cell $\left(23^{\circ} \mathrm{C}\right)$. At the completion of the solid/liquid contact, the solution was separated from the exchanger by filtration through a $0.2-\mu \mathrm{m}$ syringe filter, and two $0.5-\mathrm{mL}$ aliquots of solution were withdrawn for analytical purposes.

\subsubsection{Multiple Contact (High DF) Method}

In order to demonstrate the achievable DF, multiple batch contacts were performed with relatively large amounts $(0.5 \mathrm{~g})$ of exchanger. Each additional contact removes cesium and strontium and provides an estimate of the achievable DF along with data at additional phase ratios. While this experiment does not predict the DFs that might be achieved by a column operation, it at least indicates the decontamination limits that may result from nonexchangeable forms of the cesium.

In order to reduce the quantity of actual waste required for these tests, residual solution (containing no additional cesium) from previous tests (Section 2.6.1) were used. In those cases, $0.067 \mathrm{~g}$ of each material was separately contacted with $10 \mathrm{~mL}$ of actual waste. After performing the solid/liquid separation and removing aliquots for analytical samples, the residual solutions $(\sim 8$ $\mathrm{mL}$ ) were contacted with $0.5 \mathrm{~g}$ of fresh material under the same conditions as previously described (72-hour contact, $25^{\circ} \mathrm{C}$ ). After the second solid/liquid separation and analytical samples were removed, a third contact with $0.5 \mathrm{~g}$ of fresh resin and the residual solution $(\sim 6 \mathrm{~mL})$ was proposed but not completed. Although the solid/liquid phase ratio was not constant over the course of the testing, the data can still be used to indicate the ability of each material to achieve a high DF.

\subsubsection{High Phase Ratio Method}

In order to adequately investigate the effect of interfering components on cesium uptake, it is necessary to contact the exchangers with a relatively high ratio of supernate-to-exchanger. This high phase ratio simulates the inlet portion of the exchanger bed, where the exchanger encounters a relatively large amount of waste. It is expected that components that foul or preferentially exchange will concentrate in this region.

It is desirable to have a phase ratio at least as high as the $\mathrm{K}_{\mathrm{d}}$ and preferably from two to three times higher. The phase ratio in the cesium addition method (Section 2.6.1) is $10 \mathrm{~mL}: 0.067 \mathrm{~g}$ or $150 \mathrm{~mL} \mathrm{~g}^{-1}$. Of the materials to be tested, only CS-100 and TIE-96 had $\mathrm{K}_{\mathrm{d}} \mathrm{s}$ significantly less than this. Due to the limited quantity of actual waste available for the current experiments, a phase ratio of 1000 was used. In the tests described in this section, a smaller quantity of material (i.e., $10 \mathrm{mg} \mathrm{IE}-910,10 \mathrm{mg} \mathrm{IE}-911,20 \mathrm{mg} \mathrm{R}-\mathrm{F}$, and $20 \mathrm{mg}$ SL-644) was individually contacted with fresh $(10 \mathrm{~mL})$ portions of the actual waste. All other variables were the same as described in Section 2.3 (e.g., $23^{\circ} \mathrm{C}$ and 72 hour contact). 


\subsection{Chemical and Radionuclide Analysis}

While the removal of ${ }^{137} \mathrm{Cs}$ is the primary radionuclide of interest, information on the ion exchange behavior of strontium, TRU components (plutonium, americium), and other cations may also be obtained from the actual waste testing. The performed analyses included gamma energy analysis (GEA), alpha total (AT), and inductively coupled plasma atomic emission spectroscopy (ICP-AES) (for the nonspiked solutions). In order to reduce costs, radioactive ${ }^{85} \mathrm{Sr}$ was added into the stock solutions at $8.6 \mu \mathrm{Ci} \mathrm{mL} L^{-1}$ to allow the strontium concentration to be tracked by GEA. The relatively inexpensive AT analyses were performed to determine the total alpha levels in the solutions. ICP-AES analysis was performed to provide an indication of what interfering species might be removed by the ion exchange materials. 



\subsection{Results and Discussion}

\subsection{Exchanger Properties}

The materials examined in this test exhibit a wide variety of physical, chemical, and ion exchange properties that can greatly affect their ability to remove cesium and/or strontium from solution. An esti- . mate of the bed density was obtained by adding each material to a $25-\mathrm{mL}$ graduated cylinder containing $2 \mathrm{M} \mathrm{NaOH}$ and allowing the mixture to settle for approximately 24 hours. The results of this test are displayed in Table 3.1. The cylinder was gently tapped to facilitate packing of the materials. The density of the finely powdered materials (e.g., $\mathrm{NaTi}$ and IE-910) was determined in the absence of $2 \mathrm{M} \mathrm{NaOH}$. In practice, the bed density of a.large scale ion exchange column will probably differ slightly from these results due to size, wall, or solution effects. The density of some materials is more sensitive to solution composition changes than other materials and may differ in an actual waste matrix from that obtained in $2 \mathrm{M} \mathrm{NaOH}$. For example, the density of the organic materials may vary widely (especially with changing $\mathrm{pH}$ ), whereas the density of the inorganic materials generally does not change.

In general, the organic materials exhibited a lower density than the inorganic materials in the $2 \mathrm{M} \mathrm{NaOH}$ solution. In particular, the density of the SuperLig ${ }^{8} 644$ material was such that it floated on top of the waste matrix for several hours during the solid/liquid contact. Adequate contact was achieved as the material eventually swelled and sank to the bottom of the container. Also, the two powdered exchangers (e.g., NaTi and IE-910) consist of submicron particles. The dry bed densities of these materials will depend on how vigorously the column packing procedure is completed and hence

Table 3.1. Physical Properties of Exchangers

\begin{tabular}{||l|c|c|}
\hline \multicolumn{1}{|c|}{ Material } & F Factor & Dry Density, mL $^{-1}$ \\
\hline \hline CS-100 & 0.6148 & 0.2434 \\
\hline TIE-96 & 0.8338 & 0.7672 \\
\hline R-F & 0.8070 & 0.3044 \\
\hline SL-644 & 0.9751 & $0.2238^{(*)}$ \\
\hline IE-910 & 0.9680 & $0.7738^{(0)}$ \\
\hline IE-911 (38B) & 0.8870 & 1.1300 \\
\hline IE-911 (08) & 0.8990 & 0.8999 \\
\hline NaTi & 0.9764 & $0.5812^{(0)}$ \\
\hline $\begin{array}{l}\text { (a) Density obtained from Brown et al. (1995b) in NCAW simulant. } \\
\text { (b) Density obtained from dry material (no solution added). }\end{array}$ \\
\hline
\end{tabular}


exhibits a large uncertainty. Although such small particles would not be practical in a large-scale column process, these materials were added to the current experiment for comparison purposes. A mass basis $\left(\mathrm{K}_{\mathfrak{d}}\right)$ rather than the volume basis $(\lambda)$ comparison is probably more meaningful for these materials.

\subsection{Actual Waste Preparation}

The actual waste solution used in this experiment was a composite mixture from three DSSF tanks (70\% 101-AW, 20\% 106-AP, and 10\% 102-AP) prepared by volume. Two bottles (identified by WHC as $\mathrm{J}-1278$ and J-1279) of concentrated (ca. 9.64 M Na) waste were received from D.L. Herting (WHC) in March 1994. The samples were archived in the 325 B hotcell at Northwest National Laboratory on March 15,1994 , as 94-002537 (J-1278) and 94-002538 (J-1279). A separate volume of the original waste solution was characterized by WHC personnel for other purposes. The results of these analyses are displayed in Table 3.2 and are described in a WHC internal letter. ${ }^{\mathrm{a}}$

The original composite waste was reanalyzed at PNL (Table 3.3) for sodium, potassium, and various metals by ICP-AES, for cesium- 137 by GEA, and for cesium isotopic ratios by thermal ionization mass spectroscopy (TIMS). Following this analytical confirmation, the contents of the two shipping containers were combined to form a single actual waste stock solution that was spiked with $5 \mathrm{mCi}$ of a ${ }^{85} \mathrm{Sr}$ tracer and diluted with water to approximately $5 \mathrm{M}$ Na. Subsequent sodium analyses on control samples $(\mathrm{N}=16$ ) indicated the solution had a sodium concentration of $4.96 \pm 0.19 \mathrm{M}$ after the dilution. The diluted solution had a specific gravity $(\mathrm{SpG})$ of $1.261 \mathrm{~g} \mathrm{~mL}^{-1}$. The $\mathrm{SpG}$ of the undiluted waste was $1.416 \mathrm{~g} \mathrm{~mL}^{-1}$.

The solution was mixed overnight to achieve isotopic exchange equilibrium and then filtered through a $0.2-\mu \mathrm{m}$ filter yielding $0.85 \%$ weight percent residual solids. After the ${ }^{85} \mathrm{Sr}$ addition, dilution, and filtration steps, the filtrate solution was crystal clear with no visible color or solids present. The waste contains relatively high concentrations of phosphate and carbonate, which might result in the formation of insoluble strontium phosphate or carbonate. Addition of strontium- 85 tracer, even in minute molar quantities, may exceed the solubility product and result in the precipitation of total strontium. For this reason, the strontium-85 tracer was allowed to equilibrate overnight with stirring and was filtered before use. This eliminates the possibility of precipitation during the experimental contacts and isolates the batch contact process to ion exchange and/or sorption only (not precipitation).

The previously prepared stock solution (spiked with ${ }^{85} \mathrm{Sr}$, filtered, and diluted to $\approx 5 \mathrm{M} \mathrm{Na}$ ) was then subsampled into four separate bottles, each containing a different amount of solid $\mathrm{CsNO}_{3}$. These bottles were prepared by evaporating a standardized $0.09782 \mathrm{M}$ Cs solution of cesium nitrate $(0.00,0.26,3.25$, and $33.15 \mathrm{~mL}$ ). The mixtures were stirred for a minimum of 8 hours to ensure that the

(a) D.L. Herting. 1994. Strontium Removal Study--Feed Characterization. Internal letter \#12110-PCL94-017, February 16, 1994. Westinghouse Hanford Company, Richland, Washington. 
Table 3.2. Comparison of DSSF Actual and Simulant Waste Solutions

\begin{tabular}{|c|c|c|c|c|c|c|}
\hline Analyte & Units & $\begin{array}{l}\text { Room } \\
\text { Temp. }\end{array}$ & $\begin{array}{c}\text { Tank } \\
\text { Temp. }\end{array}$ & $\begin{array}{l}\text { Diluted to } \\
5 \mathrm{M} \mathrm{Na}^{\text {(a) }}\end{array}$ & $\begin{array}{l}\text { Northwest National } \\
\text { Laboratory Analysis }\end{array}$ & $\begin{array}{l}\text { Northwest. National } \\
\text { Laboratory Simulant }\end{array}$ \\
\hline "Solids & $\overline{\mathrm{Wt} \%}$ & $\overline{5.8^{(b)}}$ & $3.5^{(\mathrm{b})}$ & $1.3^{(\mathrm{b})}$ & $0.85^{(\mathrm{c})}$ & $\overline{N^{\prime} R^{(d)}}$ \\
\hline$\overline{\mathrm{SpG}}$ & $\mathrm{g} \mathrm{g}^{-1}$ & 1.39 & 1.42 & 1.21 & 1.261 & 1.26 \\
\hline$\% \cdot \mathrm{H}_{2} \mathrm{O}$ & Wt \% & 54.2 & 50.9 & 72.4 & NR & $\overline{\mathrm{NR}}$ \\
\hline $\mathrm{AT}$ & $\mu \mathrm{Ci} \mathrm{mL}$ & $1.24 \mathrm{E}-02$ & $2.30 \mathrm{E}-02$ & $7.0 \mathrm{E}-03$ & $<3 \mathrm{E}-03$ & $\mathrm{NA}^{(\mathrm{e})}$ \\
\hline${ }^{137} \mathrm{Cs}$ & $\mu \mathrm{Ci} \mathrm{mL}$ & $2.5 \mathrm{E}+02$ & $4.40 \mathrm{E}+02$ & $1.50 \mathrm{E}+02$ & $1.99 \mathrm{E}+02$ & NA \\
\hline${ }^{90} \mathrm{Sr}$ & $\mu \mathrm{Ci} \mathrm{mL}^{-}$ & $2.7 \mathrm{E}-01$ & $4.6 \mathrm{E}-01$ & $1.6 \mathrm{E}-01$ & $\overline{N R}$ & $\overline{\mathrm{NA}}$ \\
\hline TOC & $\mathrm{g} \mathrm{L}^{-1}$ & $4.2 \mathrm{E}+00$ & $3.72 \mathrm{E}+01$ & $2.16 \mathrm{E}+00$ & NR & $\overline{\mathrm{NA}}$ \\
\hline TIC & $\underline{\mathrm{M}}$ & $2.1 \mathrm{E}-01$ & $2.3 E-01$ & $1.3 \mathrm{E}-01$ & $\overline{N R}$ & $1.40 \mathrm{E}-01$ \\
\hline $\mathrm{OH}^{-}$ & $\underline{M}$ & $4.41 \mathrm{E}+00$ & $5.39 \mathrm{E}+01$ & $2.01 \mathrm{E}+00$ & NR & $2.17 \mathrm{E}+00$ \\
\hline $\mathrm{F}^{-}$ & $\underline{\mathrm{M}}$ & $7.0 \mathrm{E}-02$ & $--^{(\text {() }}$ & - & NR & $4.33 \mathrm{E}-02$ \\
\hline $\mathrm{Cl}^{-}$ & $\underline{M}$ & $1.2 \mathrm{E}-01$ & $1.6 \mathrm{E}-01$ & $0.6 \mathrm{E}-03$ & NR & $6.50 \mathrm{E}-02$ \\
\hline $\mathrm{NO}_{2}^{-}$ & $\underline{\bar{M}}$ & $1.62 \mathrm{E}+00$ & $2.07 \mathrm{E}+00$ & $8.1 \mathrm{E}-01$ & $\overline{N R}$ & $9.40 \mathrm{E}-01^{\circ}$ \\
\hline $\mathrm{NO}_{3}^{-}$ & $\underline{\mathrm{M}}$ & $2.54 \mathrm{E}+00$ & $3.27 \mathrm{E}+00$ & $1.34 \mathrm{E}+00$ & NR & $1.49 \mathrm{E}+00$ \\
\hline $\mathrm{PO}_{4}^{3-}$ & $\underline{\underline{M}}$ & $<4 \mathrm{E}-03$ & - & $1.6 \mathrm{E}-02$ & NR & $1.75 \mathrm{E}-02$ \\
\hline $\mathrm{SO}_{4}^{2-}$ & $\underline{\mathrm{M}}$ & $1.5 \mathrm{E}-02$ & $1.5 \mathrm{E}-02$ & $1.0 \mathrm{E}-02$ & $\overline{N R}$ & $1.26 \mathrm{E}-02$ \\
\hline $\mathrm{Na}$ & $\underline{\mathrm{M}}$ & $9.64 \mathrm{E}+00$ & $1.07 \mathrm{E}+01$ & $4.67 \mathrm{E}+00$ & $(4.96 \pm 0.19) \bar{E}+00$ & $5.00 \mathrm{E}+00$ \\
\hline$\overline{\mathrm{K}}$ & $\overline{\bar{M}}$ & $9.2 \mathrm{E}-01$ & $9.5 \mathrm{E}-01$ & $4.4 \mathrm{E}-01$ & $(4.78 \pm 0.13) \mathrm{E}-01$ & $4.75 \mathrm{E}-01$ \\
\hline$\overline{\mathrm{Al}}$ & $\underline{\mathrm{M}}$ & $8.6 \mathrm{E}-01$ & $9.5 \mathrm{E}-01$ & $4.6 \mathrm{E}-01$ & $(4.71 \pm 0.12) \mathrm{E}-01$ & $4.97 \mathrm{E}-01$ \\
\hline $\mathrm{S}$ & $\underline{\mathrm{M}}$ & 1.7E-02 & $1.8 \mathrm{E}-02$ & $9.1 \mathrm{E}-03$ & NR & $\overline{\mathrm{NA}}$ \\
\hline $\bar{P}$ & $\underline{\mathrm{M}}$ & $9.0 \mathrm{E}-03$ & $8.8 \mathrm{E}-03$ & $1.8 \mathrm{E}-02$ & $(1.43 \pm 0.05) \mathrm{E}-02$ & $1.75 \mathrm{E}-02$ \\
\hline $\mathrm{Cr}$ & $\underline{\underline{M}}$ & $3.1 \mathrm{E}-03$ & $3.4 \mathrm{E}-03$ & $1.9 \mathrm{E}-03$ & $(2.11 \pm 0.03) \mathrm{E}-03$ & NA \\
\hline
\end{tabular}


Table 3.2. (contd)

\begin{tabular}{|c|c|c|c|c|c|c|}
\hline Analyte & Units & $\begin{array}{l}\text { Room } \\
\text { Temp. }{ }^{(\mathrm{a})}\end{array}$ & $\begin{array}{c}\text { Tank } \\
\text { Temp. }^{(a)}\end{array}$ & $\begin{array}{l}\text { Diluted to } \\
5 \mathrm{M} \mathrm{Na}^{(\mathrm{a})}\end{array}$ & $\begin{array}{l}\text { Northwest National } \\
\text { Laboratory Analysis }\end{array}$ & $\begin{array}{l}\text { Northwest National } \\
\text { Laboratory Simulant }\end{array}$ \\
\hline$\overline{\mathrm{Si}}$ & $\underline{\bar{M}}$ & 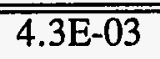 & $3.6 \mathrm{E}-03$ & $1.9 \mathrm{E}-03$ & 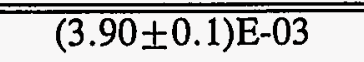 & $\overline{\mathrm{NA}}$ \\
\hline $\mathrm{Sr}$ & $\underline{\underline{M}}$ & -- & - & $\overline{-}$ & $(1.31 \pm 0.08) \mathrm{E}-05$ & $7.14 \mathrm{E}-08$ \\
\hline $\bar{B}$ & $\underline{\mathrm{M}}$ & $9.2 \mathrm{E}-03$ & $1.04 \mathrm{E}-02$ & $5.8 \mathrm{E}-03$ & $(1.24 \pm 0.2) \mathrm{E}-02$ & $\mathrm{NA}$ \\
\hline Mo & $\underline{\mathbf{M}}$ & $4.6 \mathrm{E}-04$ & .5.0E-04 & $2.7 \mathrm{E}-04$ & $(3.02 \pm 0.2) \mathrm{E}-04$ & $\mathrm{NA}$ \\
\hline $\mathrm{Pb}$ & $\underline{\mathrm{M}}$ & $1.1 \mathrm{E}-04$ & $1.2 \mathrm{E}-04$ & $0.5 \mathrm{E}-04$ & $(1.29 \pm 0.6) \mathrm{E}-04$ & $\mathrm{NA}$ \\
\hline $\mathrm{Ni}$ & $\underline{\mathrm{M}}$ & $2.4 \mathrm{E}-04$ & $2.6 \mathrm{E}-04$ & $1.4 \mathrm{E}-04$ & $(1.49 \pm 0.1) \mathrm{E}-04$ & $\mathrm{NA}$ \\
\hline$\overline{\mathrm{Ca}}$ & $\mathrm{M}$ & $3.4 \mathrm{E}-04$ & $3.2 \mathrm{E}-04$ & $2.4 \mathrm{E}-04$ & $(8 \pm 4) \mathrm{E}-04$ & $2.41 \mathrm{E}-04$ \\
\hline$\overline{\mathrm{Zr}}$ & $\underline{\mathrm{M}}$ & $1.2 \mathrm{E}-04$ & $1.4 \mathrm{E}-04$ & $0.7 \mathrm{E}-04$ & $(5.55 \pm 0.5) \mathrm{E}-05$ & NA \\
\hline$\overline{\mathrm{Zn}}$ & $\underline{\underline{M}}$ & $3.1 \mathrm{E}-04$ & $1.3 \mathrm{E}-04$ & $0.9 \mathrm{E}-04$ & $(8.0 \pm 1.3) \mathrm{E}-05$ & $\mathrm{NA}$ \\
\hline $\mathrm{Sb}$ & $\underline{\underline{M}}$ & $5.0 \mathrm{E}-05$ & $8.0 \mathrm{E}-05$ & $\overline{-}$ & -- & NA \\
\hline $\mathrm{Fe}$ & $\underline{\mathrm{M}}$ & $1.1 \mathrm{E}-04$ & $2.0 \mathrm{E}-04$ & $0.7 \mathrm{E}-04$ & - & $\mathrm{NA}$ \\
\hline $\mathrm{Mn}$ & $\underline{\mathrm{M}}$ & $.0 .8 \mathrm{E}-04$ & $1.3 \mathrm{E}-04$ & -- & -- & $\mathrm{NA}$ \\
\hline$\overline{\mathrm{Cd}}$ & $\underline{\bar{M}}$ & $2.7 \mathrm{E}-05$ & $3.0 \mathrm{E}-05$ & $2.0 \mathrm{E}-05$ & $(1.22 \pm 0.9) \mathrm{E}-04$ & $\mathrm{NA}$ \\
\hline$\overline{\mathrm{Be}}$ & $\overline{\bar{M}}$ & 2.1E-04 & $2.3 \mathrm{E}-04$ & $1.3 \mathrm{E}-04$ & $(1.22 \pm 0.04) \mathrm{E}-04$ & $\overline{\mathrm{NA}}$ \\
\hline $\mathrm{Ba}$ & $\underline{\mathrm{M}}$ & $1.1 \mathrm{E}-06$ & $0.2 \mathrm{E}-05$ & -- & $<1.45 \mathrm{E}-05$ & 5.91E-07. \\
\hline \multicolumn{7}{|c|}{$\begin{array}{l}\text { (a) WHC chemical analysis of the a } \\
\text { (b) Centrifuged solids. } \\
\text { (c) Filtered }(0.2 \mu \mathrm{m}) \text { solids. } \\
\text { (d) Analysis not requested. } \\
\text { (e) Species not added to simulant. } \\
\text { (f) Analyte below detection limit. }\end{array}$} \\
\hline
\end{tabular}


Table 3.3. Additional Characterization of Actual DSSF Composite

\begin{tabular}{|l|l|}
\hline \multicolumn{1}{|c|}{ Analysis } & \multicolumn{1}{|c|}{ Analytical Results } \\
\hline Density & $1.409 \mathrm{~g} \mathrm{~mL}^{-1}$ \\
\hline Sodium & $\begin{array}{l}8.55 \mathrm{M} \mathrm{Na} \text { by ICP-AES } \\
\left(1.94 \mathrm{E}+05 \text { and } 1.99 \mathrm{E}+05 \mu \mathrm{g} \mathrm{mL}^{-1}\right)\end{array}$ \\
\hline Potassium & $\begin{array}{l}0.821 \mathrm{M} \mathrm{K} \text { by ICP-AES } \\
\left(3.21 \mathrm{E}+04 \text { and 3.19E }+04 \mu \mathrm{gL}^{-1}\right)\end{array}$ \\
\hline${ }^{137} \mathrm{Cs}$ & $\begin{array}{l}239 \mu \mathrm{Ci} \mathrm{g}^{-1} \text { by GEA } \\
\left(2.38 \mathrm{E}+02 \text { and } 2.40 \mathrm{E}+02 \mu \mathrm{Ci} \mathrm{g}^{-1}\right)\end{array}$ \\
\hline${ }^{137} \mathrm{Cs}$ & $25.98 \%$ isotopic by TIMS \\
\hline $\mathrm{Total} \mathrm{Cs}$ & $1.09 \mathrm{E}-04 \mathrm{M}$ \\
\hline $\mathrm{Na} / \mathrm{Cs}$ & $7.84 \mathrm{E}+04$ \\
\hline $\mathrm{Na} / \mathrm{K}$ & $1.04 \mathrm{E}+01$ \\
\hline $\mathrm{K} / \mathrm{Cs}$ & $7.50 \mathrm{E}+03$ \\
\hline
\end{tabular}

cesium had completely dissolved, providing a series of homogenous solutions. The cesium concentration of these subsamples was calculated to be $6.33 \mathrm{E}-05,5.00 \mathrm{E}-04,5.00 \mathrm{E}-03$, and 5.00E-02, respectively.

Blank samples, in which no ion exchange material was added to the sample vial, were used to determine the initial starting cesium concentration $\left(\mathrm{Cs}_{0}\right)$ as described in Section 2.3 for each of the four stock solutions. In this way, the blank solutions followed identical process steps as did the actual samples (e.g., glass vials, 72-hour contact, $0.2-\mu \mathrm{m}$ filtration, sample dilution, and analysis), thus ensuring that analytes were not inadvertently removed by unknown processes.

\subsection{Time-Dependent Cesium Distribution in Simulated DSSF}

The results for the time-dependent cesium batch distribution tests with simulated 70\% 101-AW DSSF composite are displayed in Figure 3.1 for each ion exchange or sorbent material. The material $\lambda$ values are displayed as a function of time from $1 \mathrm{~min}$. to 120 hours: Each data point is a separate measurement, and duplicates were not completed. In general, the low distribution materials (e.g., TIE-96 and CS-100) achieved a steady-state cesium uptake $\left(\mathrm{K}_{\mathrm{d}}\right.$ or $\lambda$ ) in approximately 2 to 20 hours. Materials with intermediate (e.g., R-F and SuperLig 644) or relatively high (e.g., IE-910 and IE-911) cesium uptake reached steady-state in 20 hours. In addition, the particle size has a large effect on the cesium uptake as a function of time. At relatively short times (i.e., less than 2 hours), the IE-910 powdered CST demonstrated a much higher cesium uptake than the engineered forms of this same material (IE-911). However, all materials appear to reach equilibrium at approximately 20 hours of contact time. 


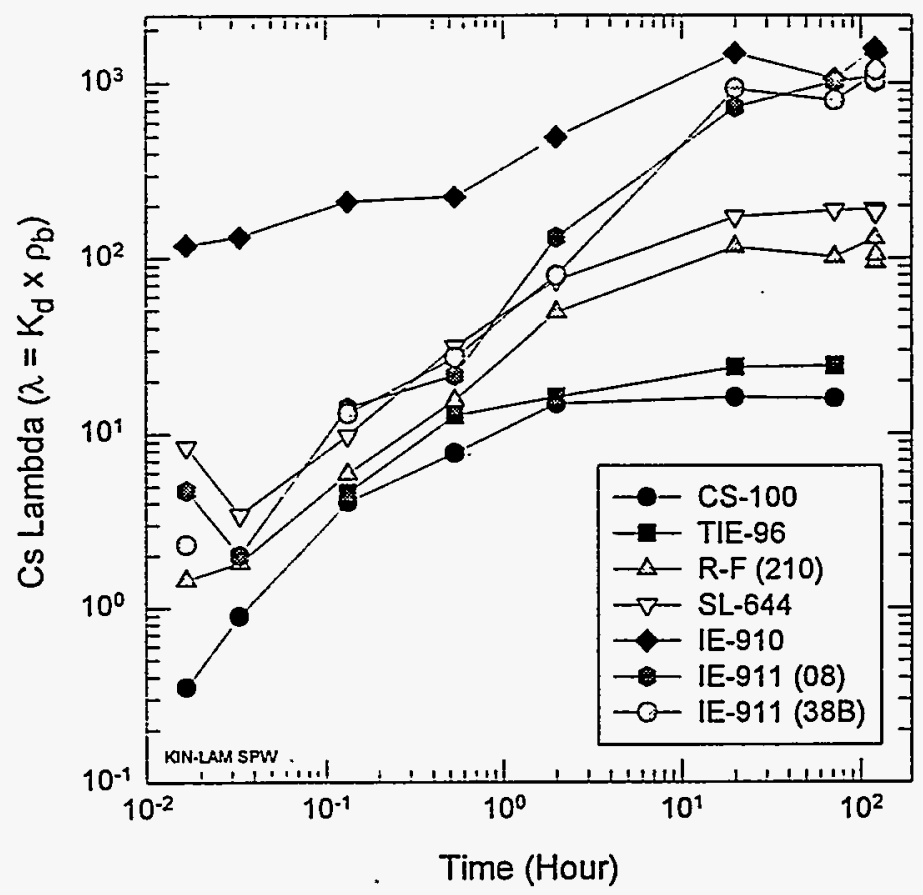

Figure 3.1. Kinetic Batch Distribution Cesium Uptake in Simulated 70\% 101-AW DSSF Composite at $5 \underline{\mathrm{M}} \mathrm{Na}, 1.00 \mathrm{E}-04 \underline{\mathrm{M}} \mathrm{Cs}$ (Initial $\mathrm{Na} / \mathrm{Cs}=5.00 \mathrm{E}+04$ ), and $25^{\circ} \mathrm{C}$

The data also indicate that solid/solution mixing has a measurable effect on the kinetics of the cesium uptake process. For example, the first two data points were completed at 1 and 2 min., respectively. The 1-min. samples were shaken manually, and the remaining samples (greater than $1 \mathrm{~min}$.) were placed into a ping-pong style shaker table.. In several cases, the cesium uptake was greater at $1 \mathrm{~min}$. than at $2 \mathrm{~min}$. Evidently, manual swirling in the first samples resulted in greater mixing and mass transport of cesium to the ion exchange site.

The data collected at 72 hours were obtained with a slightly different mixing style using an orbital shaker equipped with spring feet. In this particular case, the solution movement was much less and evidently resulted in slightly decreased cesium uptake. The actual waste tests took place in a hot cell and required using the smaller orbital shaker due to size constraints. A modification of the orbital shaker was completed, and the spring feet were replaced with solid rubber corks. The resulting shaking motion was sufficient to swirl the solution and solid materials without excessive particle/particle interactions that might physically grind the materials to a fine powder. The results from testing the three shaking methods are compared in Figure 3.1 at the 120-hour time. The data indicate that there is very little difference between the three methods, and for all practical purposes, equilibrium is reached during this period. 
It is important to note that the cesium ion exchange rates in these experiments are limited significantly by diffusion in the liquid phase and cannot be used directly to model ion exchange kinetics. More vigorous shaking will result in increased mass transfer and higher cesium uptake at shorter contact times. In any case, the flow patterns in the liquid do not easily correlate with those found in ion exchange columns.

\subsection{Cesium Distribution in Simulated DSSF}

The results for the cesium ion exchange batch distribution experiments in the 70\% 101-AW DSSF simulant are displayed in Figures 3.2 through Figure 3.8 for CS-100; TIE-96, R-F, SL-644, IE-910, IE-911(38B), and IE-911(08), respectively. The cesium $\lambda\left(\lambda=\mathrm{K}_{d} \times \rho_{b}\right)$ results are displayed as a function of equilibrium $\mathrm{Na} / \mathrm{Cs}$ ratio at several waste dilutions ([Na] $=0.2,1.0,3.0,5.0$, and 7.0). As displayed, the data demonstrate, on a single graph, a material's cesium uptake over a wide range of waste dilutions and cesium concentrations. For example, at $\mathrm{Na} / \mathrm{Cs}$ ratios greater than about $10^{6}$ (e.g., low cesium concentrations expected in sludge washes, tank rinses, process condensate, or ground water) the volume of solution that can be processed per volume of exchanger does not change appreciably. In other words, one cannot necessarily expect to process larger volumes of dilute solutions based on extrapolation of data from more concentrated solutions.

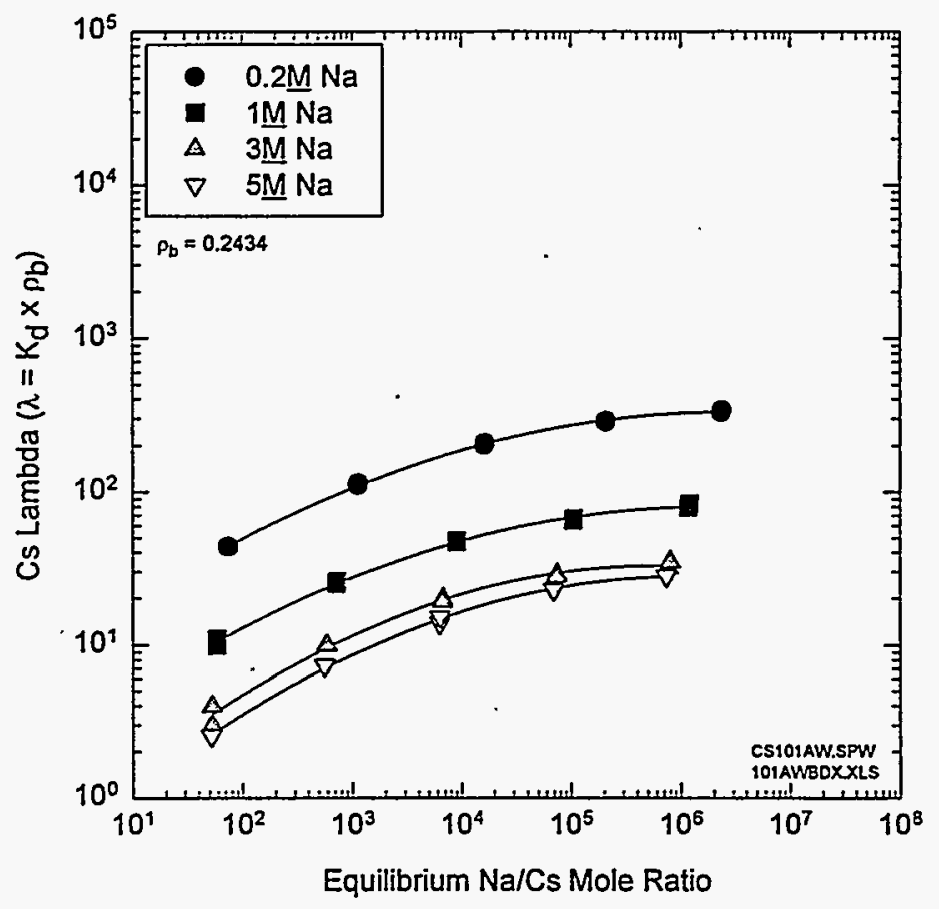

Figure 3.2. Cesium $\lambda$ Values for CS-100 in Simulated $70 \%$ 101-AW DSSF Composite at $25^{\circ} \mathrm{C}$ 


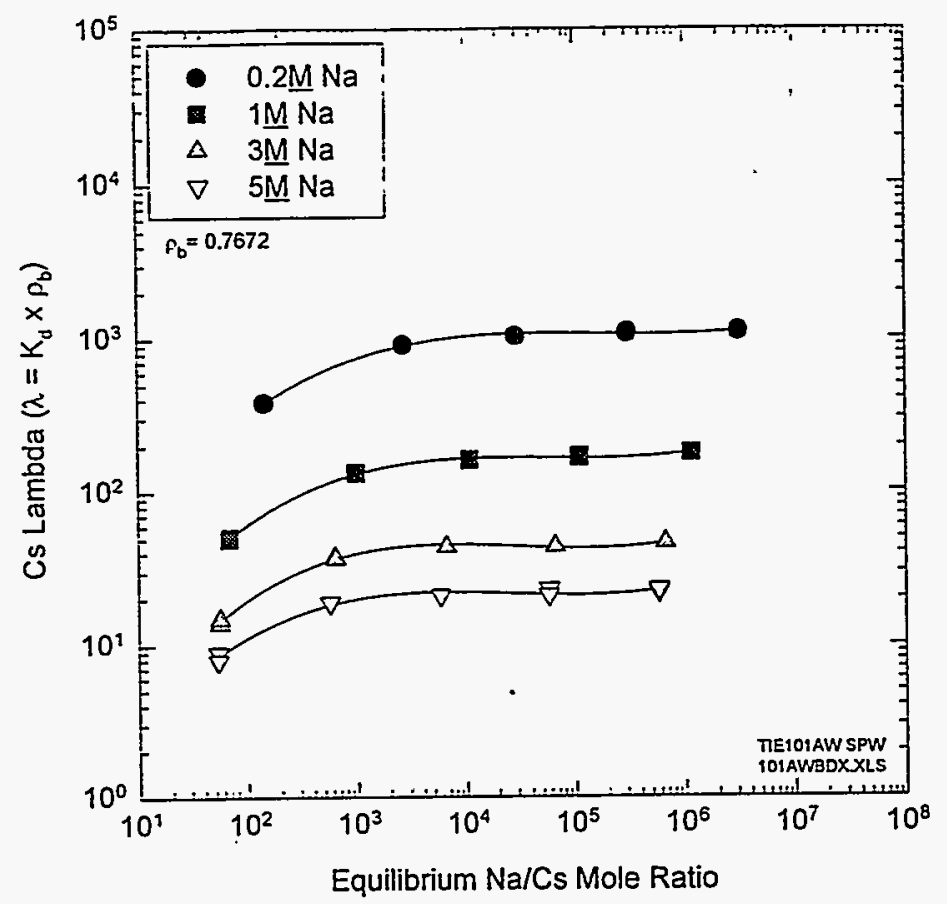

Figure 3.3. Cesium $\lambda$ Values for TIE- 96 in Simulated 70\% 101-AW DSSF Composite at $25^{\circ} \mathrm{C}$

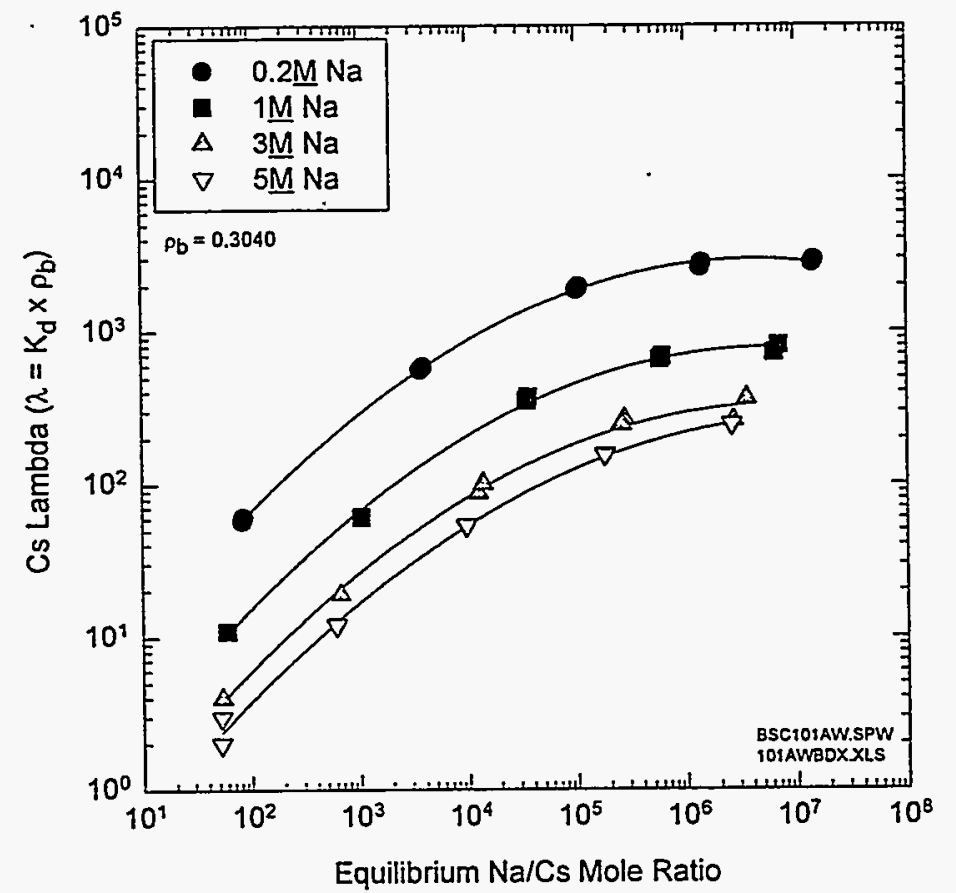

Figure 3.4. Cesium $\lambda$ Values for R-F in Simulated 70\% 101-AW DSSF Composite at $25^{\circ} \mathrm{C}$ 


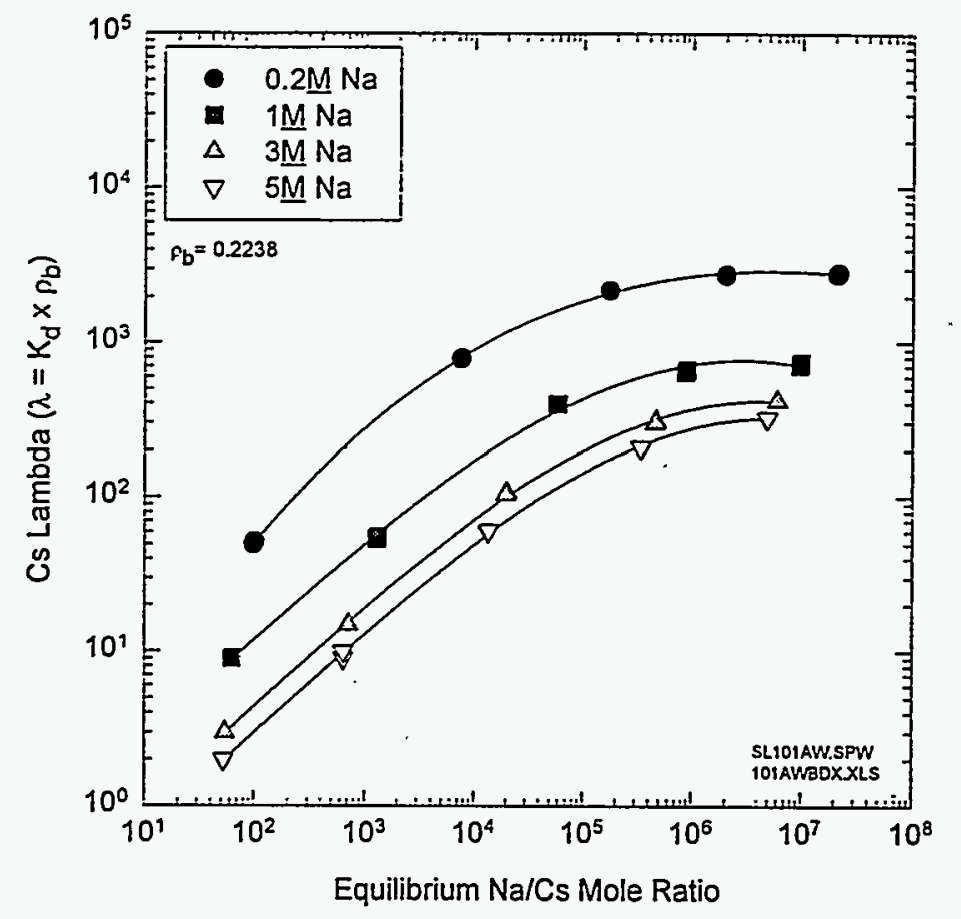

Figure 3.5. Cesium $\lambda$ Values for SL-644 in Simulated 70\% 101-AW DSSF Composite at $25^{\circ} \mathrm{C}$

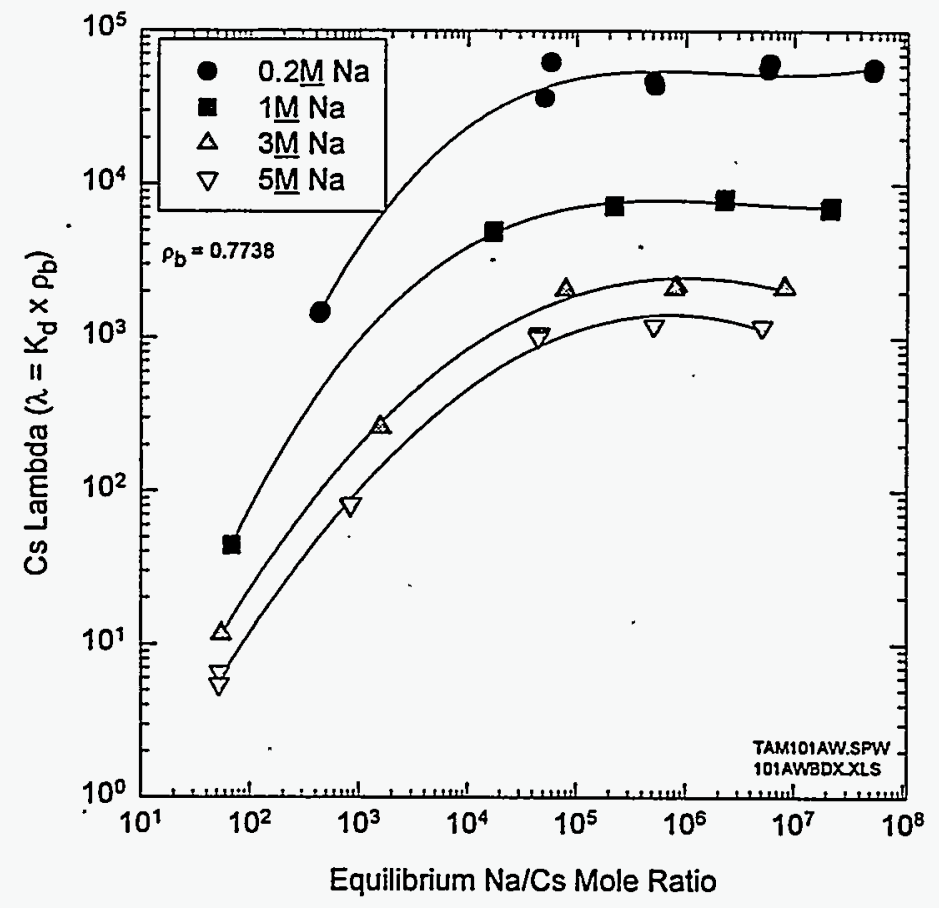

Figure 3.6. Cesium $\lambda$ Values for IE-910 in Simulated $70 \%$ 101-AW DSSF Composite at $25^{\circ} \mathrm{C}$ 


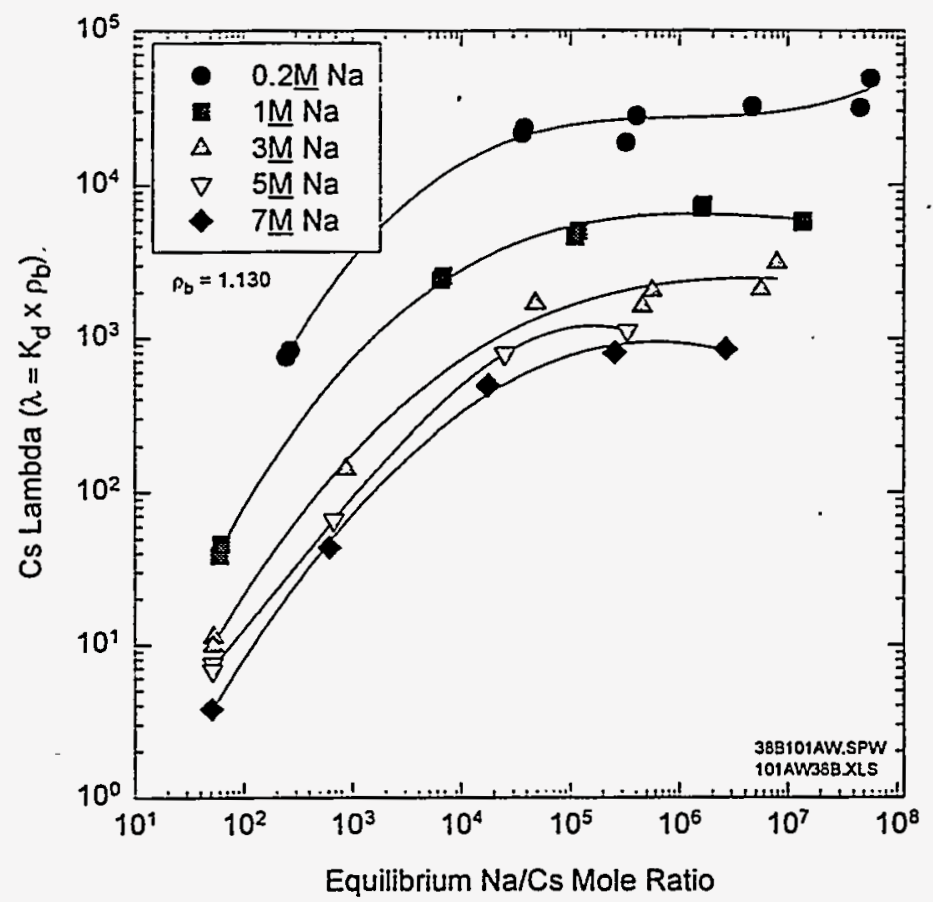

Figure 3.7. Cesium $\lambda$ Values for IE-911 (38b) in Simulated 70\% 101-AW DSSF Composite at $25^{\circ} \mathrm{C}$

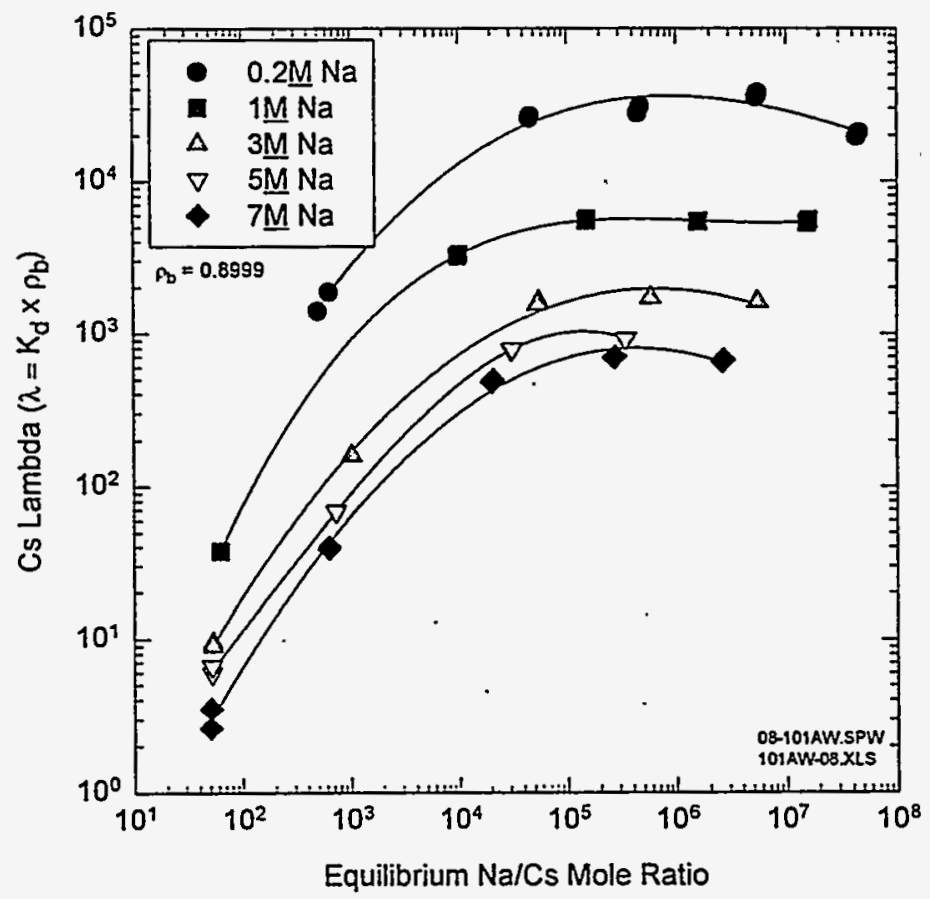

Figure 3.8. Cesium $\lambda$ Values for IE-911 (08) in Simulated 70\% 101-AW DSSF Composite at $25^{\circ} \mathrm{C}$ 
Direct comparison of the various materials can be completed using these data representations, though the process is rather tedious. For example, TIE-96 demonstrates a greater cesium loading than the CS-100 resin under all solution conditions tested (e.g., [sodium] and $\mathrm{Na} / \mathrm{Cs}$ ratios), except, perhaps at $5 \mathrm{M} \mathrm{Na}$ and $7.0 \mathrm{E}+05 \mathrm{Na} / \mathrm{Cs}$. A direct point-by-point evaluation of the data is required to make such a comparison, and such small differences easily can be overlooked.

As another example, the data suggest that dilution of this waste before processing would be beneficial for certain materials (e.g., inorganics such as TIE-96, IE-910, and IE-911), but not for others (e.g, organics such as R-F and SL-644). For TIE-96, the $\lambda$ value is approximately 20 and 1000 at $5 \underline{M}$ and $0.2 \mathrm{M} \mathrm{Na}$, respectively. Therefore, this 25 -fold dilution yields a 50 -fold increase in the diluted waste volume that can be processed per volume of zeolite material. In contrast, for $R-F$, the $\lambda$ value is about 52 and 850 at $5 \mathrm{M}$ and $0.2 \mathrm{M} \mathrm{Na}(\mathrm{Na} / \mathrm{Cs}=1.0 \mathrm{E}+04 \mathrm{Na} / \mathrm{Cs})$, respectively. This 25 -fold dilution results in only a 16-fold increase in volume processed per volume of resin material. Clearly, dilution would not be advantageous in this particular case.

Three forms of the crystalline silicotitanate sorbent material (powdered IE-910 and two batches of engineered IE-911) were tested in the current experiments. A direct comparison of the cesium uptake $(\lambda)$ for these materials is shown in Figures 3.9 and 3.10 as a function of Na/Cs ratio. Direct comparison on a volume basis is difficult because of the uncertainty in the IE- 910 bed density. However, it appears that the performance of the engineered IE-911 materials is fairly similar to that of the IE-910

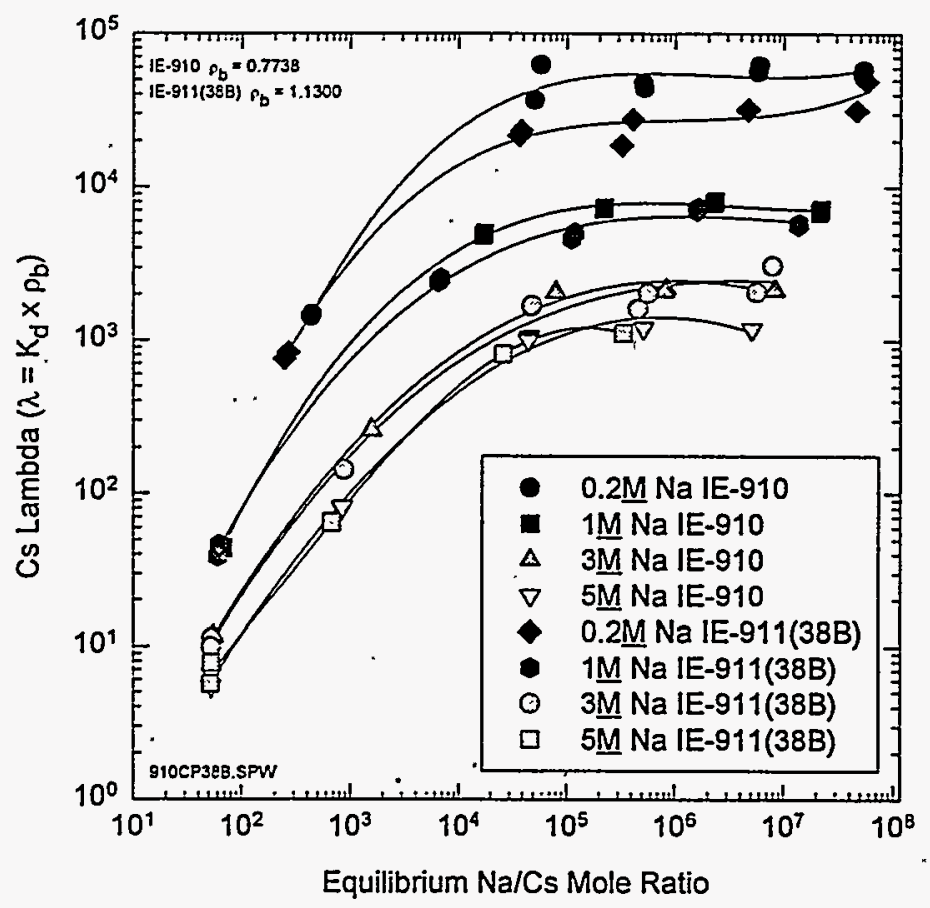

Figure 3.9. Comparison of Cesium $\lambda$ Values for Powdered (IE-910) and Engineered (IE-911[38B]) Forms of the Crystalline Silico-Titanate Sorbent Material in Simulated 70\% 101-AW DSSF Composite at $25^{\circ} \mathrm{C}$ 


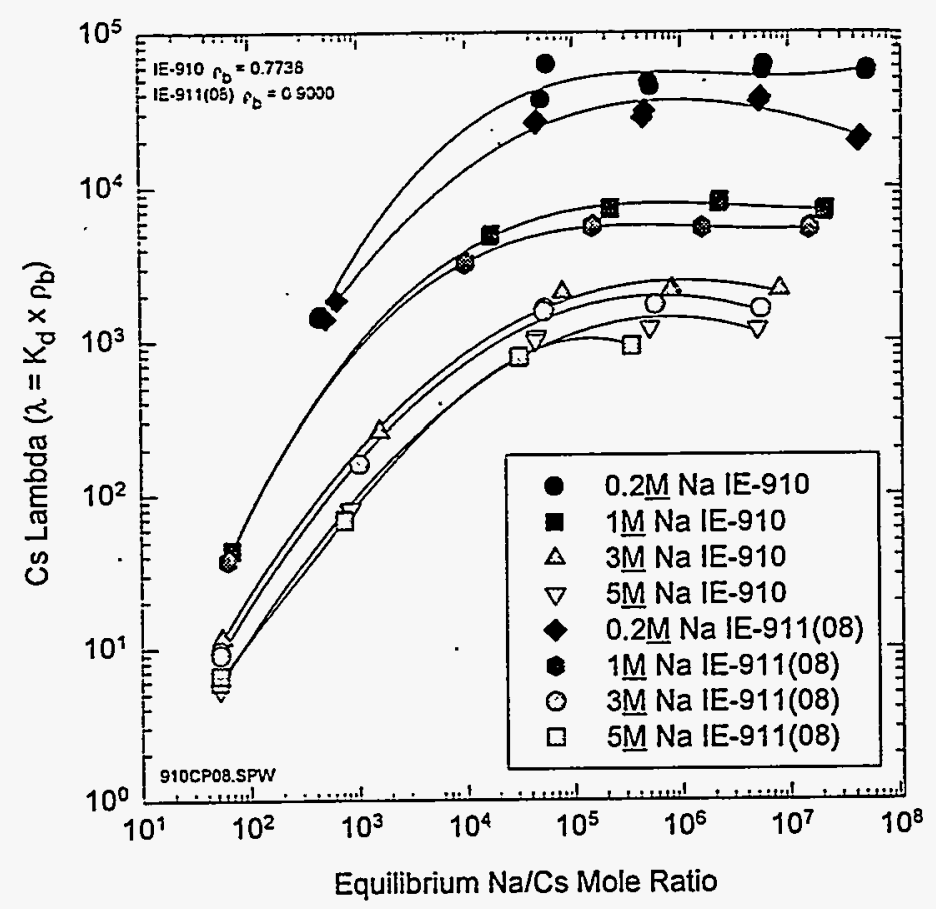

Figure 3.10. Comparison of Cesium $\lambda$ Values for Powdered (IE-910) and Engineered (IE-911[08]) Forms of the Crystalline Silico-Titanate Sorbent Material in Simulated $70 \%$ 101-AW DSSF Composite at $25^{\circ} \mathrm{C}$

powder under the conditions of the simulant testing. Comparison of the powdered and engineered materials on a mass basis $\left(\mathrm{K}_{\mathrm{d}}\right)$ can be found in Appendix B, which shows that the IE-910 demonstrates slightly higher $\mathrm{K}_{\mathrm{d}} \mathrm{s}$ than IE-911 under all conditions.

By vertically intersecting the data displayed in Figures 3.2 through 3.8 at a constant $\mathrm{Na} / \mathrm{Cs}$ ratio, the cesium loading can be displayed as a function of sodium concentration from $0.2 \underline{\mathrm{M}}$ to $7 \underline{\mathrm{M}} \mathrm{Na}$ for each individual material. The data can be combined into a single graph for rapid comparison of all materials as a function of sodium concentration. Figures 3.11 and 3.12 display these results at an equilibrium $\mathrm{Na} / \mathrm{Cs}$ ratio of $1.0 \mathrm{E}+04$ and $1.0 \mathrm{E}+06$, respectively. In these plots, the benefit of waste dilution on cesium uptake for the inorganic materials (TIE-96, IE-910, and IE-911) is clearly demonstrated by the slopes of the curves relative to the organic materials. An additional perspective on the data is displayed in Figure 3.13 by comparing the cesium uptake as a function of $\mathrm{Na} / \mathrm{Cs}$ mole ratio for all of the materials on a single plot at $5 \underline{\mathrm{M}} \mathrm{Na}$.

\subsection{Cesium Distribution in Actual DSSF}

The results of the cesium batch distribution experiments in actual 70\% 101-AW DSSF waste are displayed in Figure 3.14 as a function of equilibrium $\mathrm{Na} / \mathrm{Cs}$ ratio at a single sodium concentration 


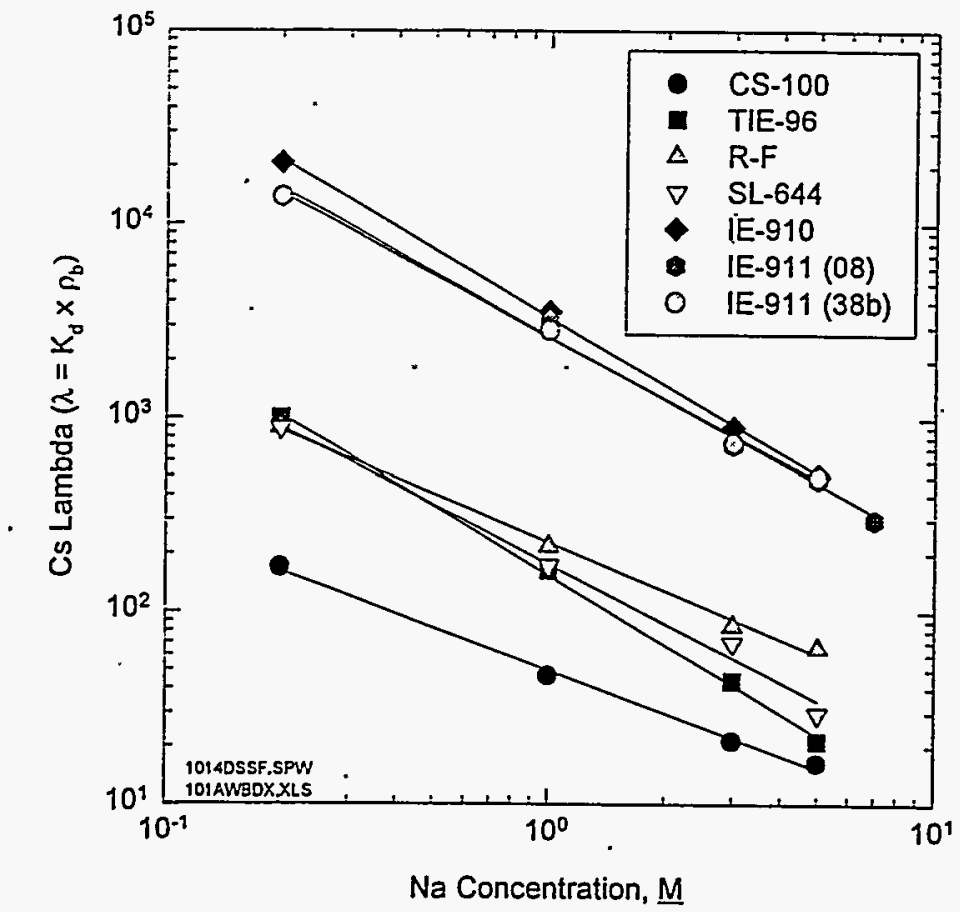

Figure 3.11. Comparison of Cesium $\lambda$ Values for Cesium-Selective Materials as a Function of Sodium Concentration in Simulated 70\% 101-AW DSSF Composite at $25^{\circ} \mathrm{C}$ and an Equilibrium $\mathrm{Na} / \mathrm{Cs}$ Ratio of $1.00 \mathrm{E}+04$

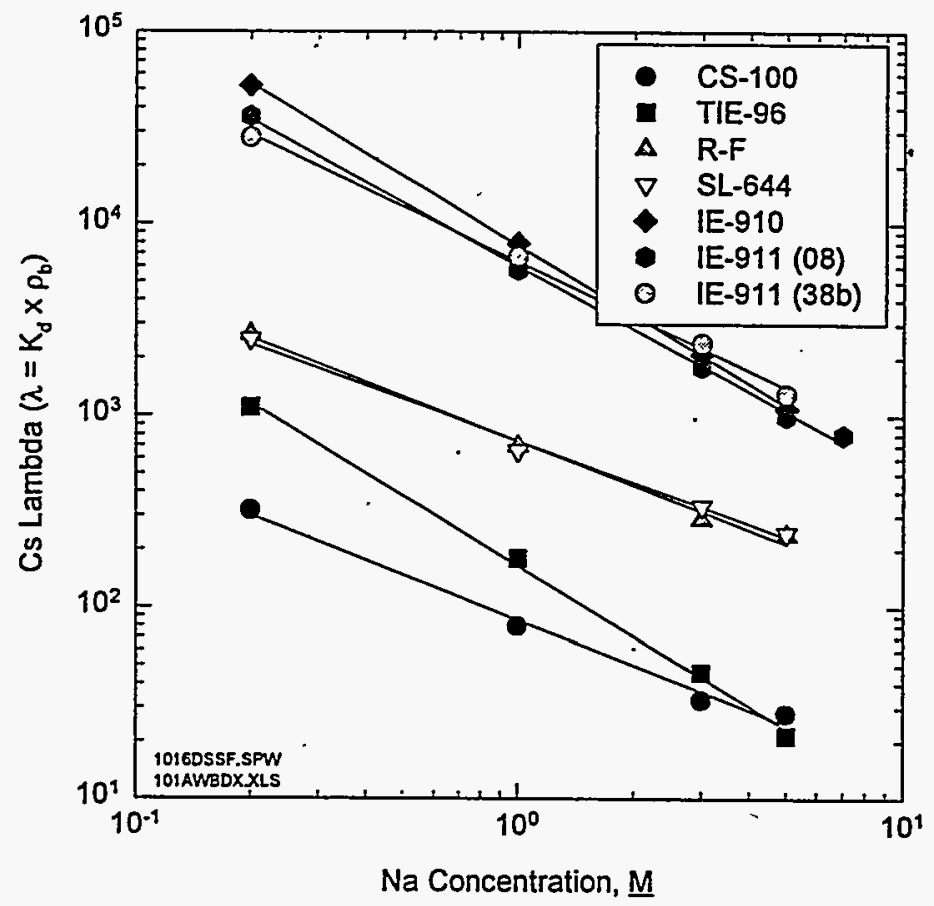

Figure 3.12. Comparison of Cesium $\lambda$ Values for Cesium-Selective Materials as a Function of Sodium Concentration in Simulated 70\% 101-AW DSSF Composite at $25^{\circ} \mathrm{C}$ and an Equilibrium Na/Cs Ratio of 1.00E +06 


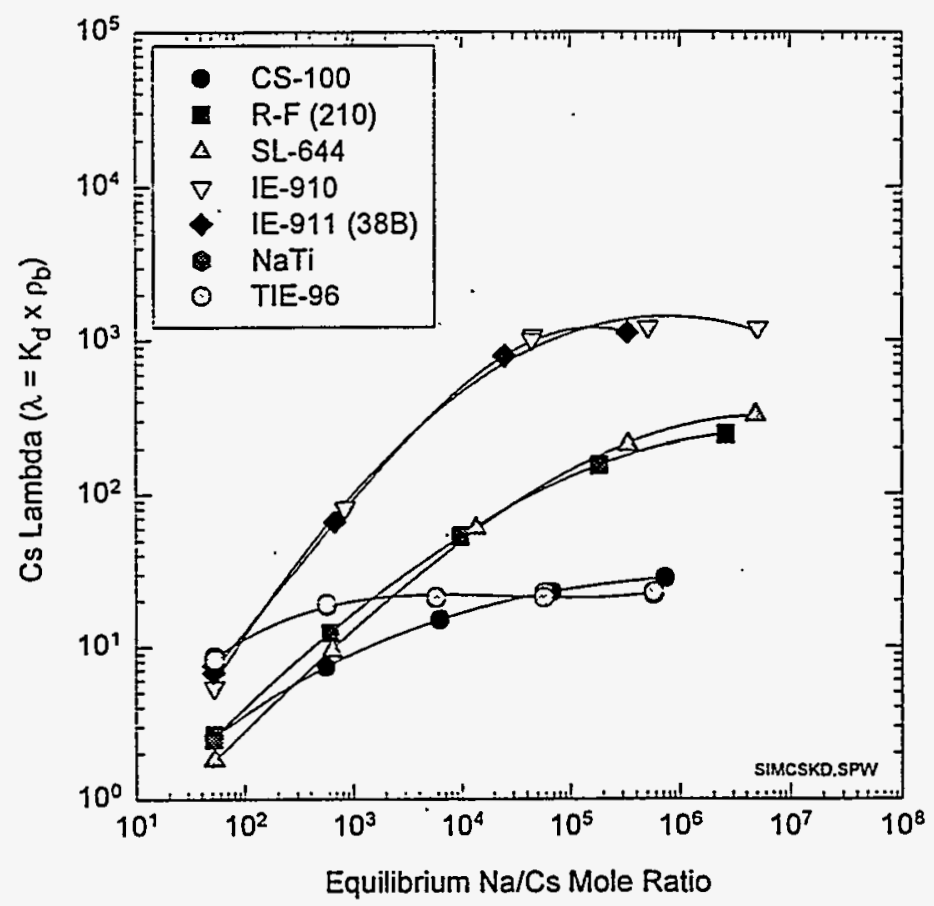

Figure 3.13. Comparison of Cesium $\lambda$ Values for Cesium Selective Materials in Simulated 70\% 101-AW DSSF Composite at $5 \underline{\mathrm{M}} \mathrm{Na}$ and $25^{\circ} \mathrm{C}$

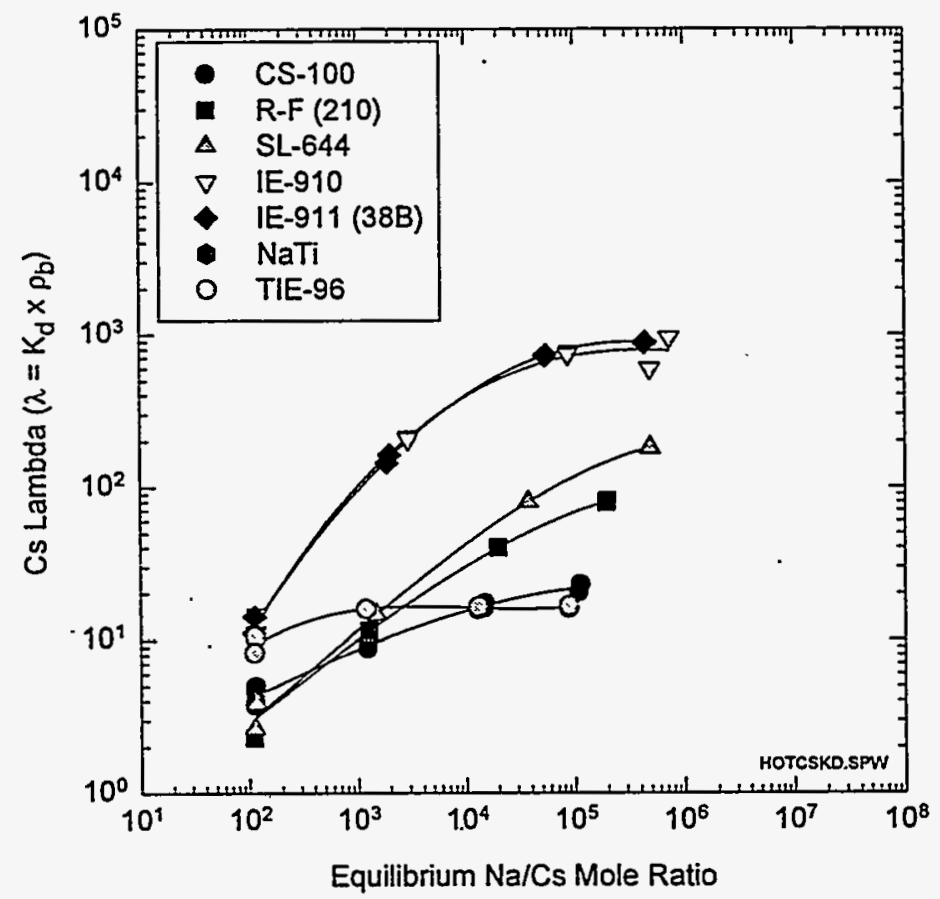

Figure 3.14. Comparison of Cesium $\lambda$ Values for Cesium Selective Materials in Actual

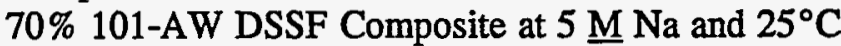


(4.96士0.19 $\mathrm{M} \mathrm{Na})$. Under all cesium concentrations tested, the CST materials (IE-910 and IE-911) exhibited greater cesium loading than any other material. As described in Section 2.6.1, the actual waste solution was subdivided into four subsamples and various quantities of additional nonradioactive cesium were added to three of the solutions. One subsample remained unchanged and exhibited an initial $\mathrm{Na} / \mathrm{Cs}$ ratio of $7.8 \mathrm{E}+04$. Assuming that these batch distribution experiments provide an accurate prediction of the column behavior of these materials, the column volumes (CV) of actual 70\% 101-AW DSSF composite waste required to reach $0.5 \mathrm{C} / \mathrm{C}_{0}$ is estimated to be $16,21,65,110,700$, and $800 \mathrm{CV}$ for TIE-96, CS-100, R-F, SL-644, IE-910, and IE-911(38B), respectively.

In addition, these actual waste results can be compared to those obtained previously for the $70 \%$ 101-AW DSSF simulant at $5 \mathrm{M} \mathrm{Na}$ from Figures 3.2 through 3.8. For visual clarity, the data are subdivided into two graphs (Figures 3.15 and 3.16), each with three materials, comparing the results for the actual and simulated wastes. In general, the actual waste results are lower than those obtained for the simulant. For the R-F and TIE-96 exchangers, the actual waste results were significantly lower than the simulant results, $-50 \%$ and $-25 \%$, respectively. The results for the CST materials were very close at low $\mathrm{Na} / \mathrm{Cs}$ mole ratios but deviated by as much as $-30 \%$ at high $\mathrm{Na} / \mathrm{Cs}$ ratios. The SL-644 and CS-100 deviations (-14\% and $-4 \%$ ) were not as great as those of the other materials. Evidently, some chemical constituents were not accurately modeled in the simulant. The effect is different for each of the various materials, suggesting that the interfering components affect each material in a slightly different way. Material differences (e.g., degradation) between the hot cell and simulant testing might also explain these results.

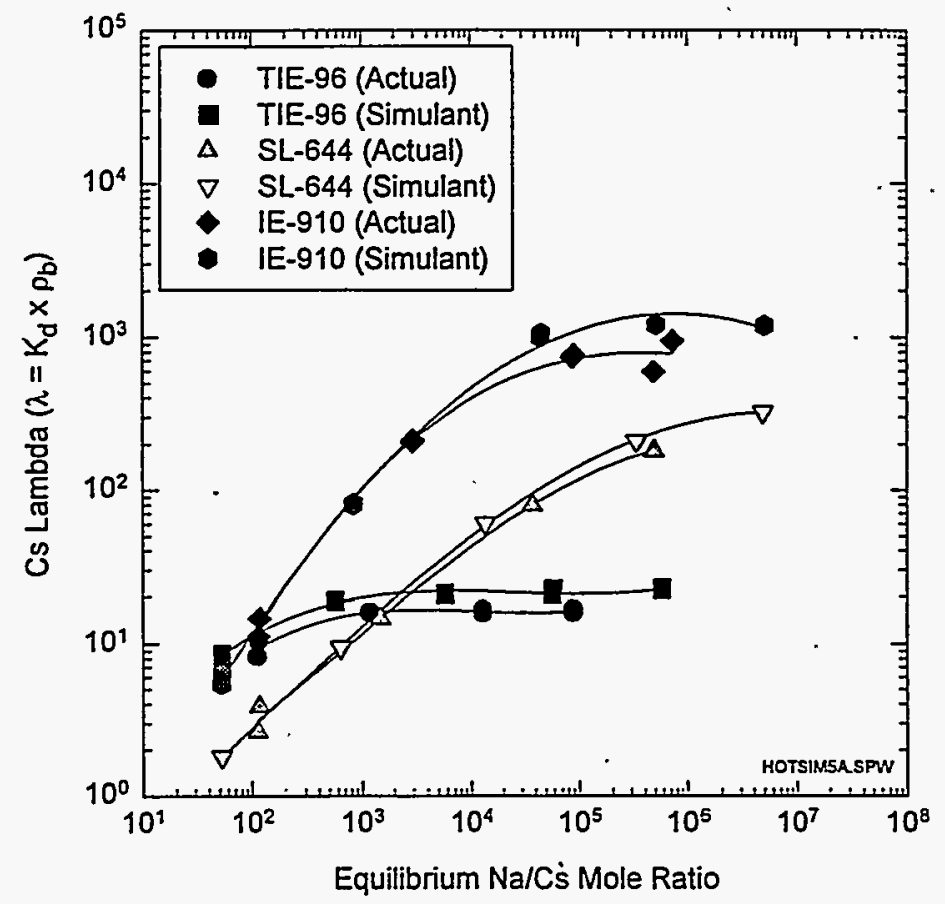

Figure 3.15. Comparison of Cesium $\lambda$ Values for Actual and Simulated 70\% 101-AW DSSF Composite at $5 \underline{\mathrm{M}} \mathrm{Na}$ and $25^{\circ} \mathrm{C}$ (TIE-96, SL-644, IE-910) 


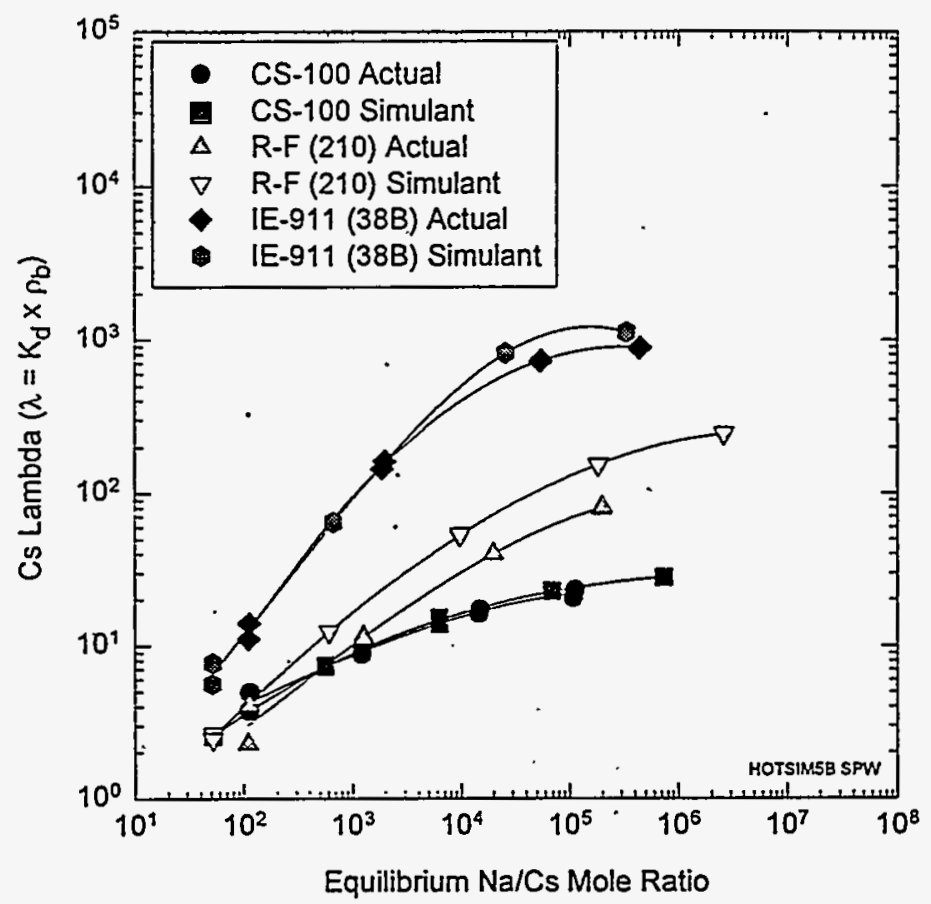

Figure 3.16. Comparison of Cesium $\lambda$ Values for Actual and Simulated 70\% 101-AW DSSF

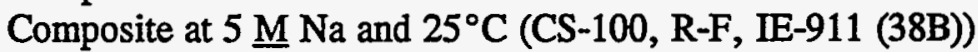

\subsection{Strontium Distribution in Actual and Simulated DSSF}

The removal of strontium from simulated and actual 70\% 101-AW DSSF waste was investigated by determining the strontium batch distribution coefficient (strontium $K_{d}$ ) and lambda (strontium $\lambda$ ) under a limited set of conditions. The actual and simulated waste solutions were traced with ${ }^{85} \mathrm{Sr}$, and the strontium concentration was determined by GEA. For the simulant experiments $(5 \mathrm{M} \mathrm{Na}$ and $5.00 \mathrm{E}+05 \mathrm{Na} / \mathrm{Cs}$ initially), the sodium titanate and crystalline silicotitanate materials removed essentially all of the strontium, giving strontium $\mathrm{K}_{\mathrm{d}}$ and $\lambda$ values greater than $1 E+06$. The zeolite TIE-96 gave a strontium $K_{d}(\lambda)$ of $4.13 E+03(3.16 E+03)$. The organic materials generally produced much lower $\lambda$ values between 18 and 38. The strontium distribution results for the simulated $70 \% 101-\mathrm{AW}$ DSSF waste are displayed in Table 3.4 at $5 \underline{\mathrm{M} \mathrm{Na}}, 1.0 \mathrm{E}-05 \underline{\mathrm{M} \mathrm{Cs}}$, and $25^{\circ} \mathrm{C}$.

The strontium $\lambda$ values obtained from the actual waste tests are displayed in Figure 3.17 as a function of equilibrium $\mathrm{Na} / \mathrm{Cs}$ mole ratio. In general, strontium removal was not affected by the concentration of cesium in the waste, although both the CS-100 resin and the IE-910 exhibit a slight dependency. This lack of dependency is not surprising since both cesium and strontium are present in low concentrations relative to the sodium and have little opportunity to interact. The equilibrium is therefore approximated by a pair of binary ion exchange interactions, one between sodium and cesium and the other between sodium and strontium. Interestingly, the strontium $K_{d}$ for the engineered CST 
Table 3.4. Strontium Distribution Results in Simulated 70\% 101-AW DSSF Waste

\begin{tabular}{|c|c|c|c|c|}
\hline Material & Sr $\mathbf{K}_{\mathrm{d}}$ & Sr $K_{d}^{(a)}$ & $\operatorname{Sr} \lambda$ & $\operatorname{Sr} \lambda^{(a)}$ \\
\hline CS-100 & $7.37 \mathrm{E}+01$ & $6.82 E+01$ & $1.79 E+01$ & $1.66 \mathrm{E}+01$ \\
\hline TIE-96 & $3.99 E+03$ & $4.27 E+03$ & $3.06 \mathrm{E}+03$ & $3.27 \mathrm{E}+03$ \\
\hline R-F & $8.42 E+01$ & $1.25 E+02$ & $2.56 \mathrm{E}+01$ & $3.82 \mathrm{E}+01$ \\
\hline SL-644 & $8.15 E+01$ & $8.46 E+01$ & $1.82 \mathrm{E}+01$ & $1.89 E+01$ \\
\hline IE-910 & $>5.93 E+06$ & $>5.93 E+06$ & $>4.58 \mathrm{E}+06$ & $>4.58 \mathrm{E}+06$ \\
\hline IE-911(08) & $\mathrm{NA}^{(\mathrm{b})}$ & $\mathrm{NA}$ & $\mathrm{NA}$ & $\mathrm{NA}$ \\
\hline IE-911(38B) & $\overline{\mathrm{NA}}$ & $\mathrm{NA}$ & $\overline{\mathrm{NA}}$ & $\mathrm{NA}$ \\
\hline $\mathrm{NaTi}$ & $>5: 79 E+06$ & $>5.88 E+06$ & $>3.37 \mathrm{E}+06$ & $>3.42 E+06$ \\
\hline \multicolumn{5}{|c|}{$\begin{array}{l}\text { (a) Duplicate. } \\
\text { (b) Not available. }\end{array}$} \\
\hline
\end{tabular}

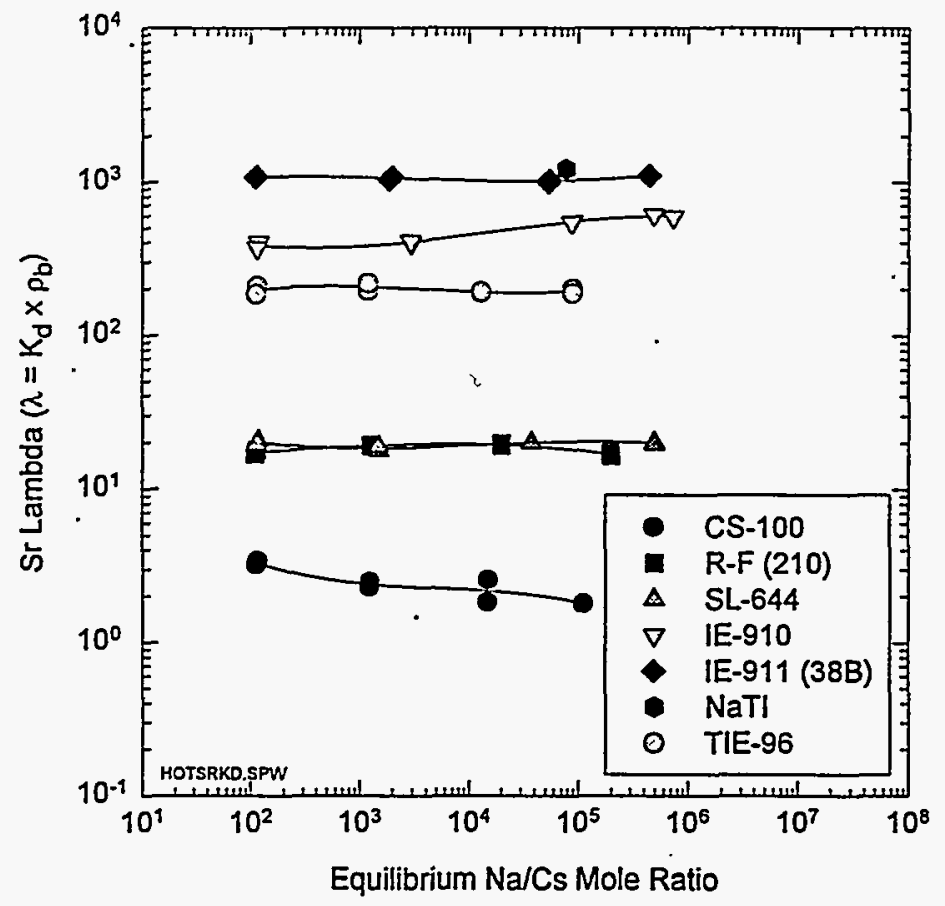

Figure 3.17. Strontium $\lambda$ Values in Actual $70 \%$ 101-AW DSSF Composite at 5 M Na and $25^{\circ} \mathrm{C}$

(IE-911[38B]) was higher than for the powdered CST (IE-910) and was not affected by the cesium concentration. The NaTi powder exhibited the highest strontium $\lambda$ but it was only slightly above the IE-911. The actual waste results generally followed those of the simulant work in the following order for strontium $\lambda$ : NaTi > IE-911 > IE-910 > TIE-96 > SL-644 > R-F > CS-100. 
As shown in Table 3.5, the strontium $\lambda$ values obtained in the actual waste tests were lower than those obtained using the simulant. These data indicate significant differences between the actual and simulated wastes with respect to strontium removal by ion exchange/sorption. Based on the chemical compositions of the simulated and actual wastes displayed in Table 3.2, it seems plausible that the differences are related to the strontium concentration, the organic components, the trace metal interferences, or differences between experimental operations between the two test facilities.

The strontium level of the simulant was determined by calculation from WHC ${ }^{90} \mathrm{Sr}$ radiochemical analysis of the actual waste (Table 3.2) and by assuming approximately $20 \%$ of the total strontium was ${ }^{90} \mathrm{Sr}$. ICP analysis of the simulant was not performed due to the less than detectable quantity of strontium. ICP analysis of the actual waste indicates that the actual strontium concentration is nearly 200 times that of the simulant. However, the strontium level cannot account for the entire difference since some strontium $\lambda$ values are more than 8,000 times lower, suggesting additional contributing factors.

Perhaps the most significant difference between the actual and simulant wastes is the level of soluble organic matter that may complex to the strontium. The actual waste contains $2.16 \mathrm{~g} \mathrm{C} \mathrm{L}^{-1} \mathrm{TOC}$, while no organics were added to the simulant due to a lack of compositional analysis. The exact nature of these organics is not known but may consist of complexants capable of binding strontium in such a form (chelated anionic metal complex) that is difficult to remove by these cationic ion exchange materials (Brown et al. 1994, Marsh et al. 1995, Orth and Kurath 1993, Samuelson 1953, Samuelson 1963).

Table 3.5. Comparison of Strontium $\lambda$ Values in Actual and Simulant 70\% 101-AW DSSF Waste

\begin{tabular}{||c|c|c|c||}
\hline \multicolumn{4}{|c|}{ Average Strontium $\lambda$} \\
\hline Material & Simulant & Actual & $\begin{array}{c}\text { Simulant/ } \\
\text { Actual }\end{array}$ \\
\hline \hline CS-100 & $1.7 \mathrm{E}+01$ & $3.7 \mathrm{E}+00$ & $5.6 \mathrm{E}+00$ \\
\hline $\mathrm{R}-\mathrm{F}$ & $3.2 \mathrm{E}+01$ & $1.7 \mathrm{E}+01$ & $1.9 \mathrm{E}+00$ \\
\hline SL-644 & $1.9 \mathrm{E}+01$ & $2.0 \mathrm{E}+01$ & $9.5 \mathrm{E}-01$ \\
\hline IE-910 & $>4.6 \mathrm{E}+06$ & $5.7 \mathrm{E}+02$ & $>8.1 \mathrm{E}+03$ \\
\hline IE-911(38B) & $\mathrm{NA}$ & $1.1 \mathrm{E}+03$ & $\mathrm{NA}$ \\
\hline IE-911(08) & $\mathrm{NA}$ & $\mathrm{NA}$ & $\mathrm{NA}$ \\
\hline TIE-96 & $3.2 \mathrm{E}+03$ & $2.0 \mathrm{E}+02$ & $1.6 \mathrm{E}+01$ \\
\hline NaTi & $>3.4 \mathrm{E}+06$ & $1.2 \mathrm{E}+03$ & $>2.8 \mathrm{E}+03$ \\
\hline (a) Not available. & & \\
\hline
\end{tabular}


It is also possible that differences in the trace metals (primarily calcium and barium, but possibly cadmium, chromium, iron, nickel, manganese, zinc, zirconium, etc.) concentrations hetween the two solutions could account for the strontium $\lambda$ variations. As displayed in Table 3.2, only calcium and barium trace metals were added to the simulant.

\subsection{Distribution of ICP Metals in Actual DSSF}

The removal of 44 other metals from the actual 70\% 101-AW DSSF composite waste was investigated by ICP-AES solution analysis before and after solid/liquid contact. A majority of the metals either were not detected (e.g., silver, arsenic, barium, bismuth, cerium, etc.), did not change appreciably during the ion exchange process (e.g., aluminum, boron, potassium, molybdenum, sodium, phosphorus, lead, zinc), or the data were too scattered to infer a statistically significant difference (e.g., calcium and nickel). However, in spite of the preponderance of irrelevant data, a number of important results, including the removal of chromium, strontium, beryllium, and zirconium, were uncovered and are displayed in Table 3.6.

Perhaps the most significant result is the chromium uptake $\left(\mathrm{Cr} \mathrm{K}_{\mathrm{f}}\right.$ ) by the organic resins (SL-644 > RF > CS-100). Similar results have been described previously (Brown et al. 1995c, Marsh et al. 1994, Svitra et al. 1994) indicating possible chromium removal for the CS-100 and R-F resins. The current data confirm this hypothesis and suggest that additional efforts should be made to quantify the extent of chromium loading during future column ion exchange experiments. Another surprising result is the slight removal of beryllium by the organic ion exchangers. The extent of strontium removal was calculated from the ICP-AES data, and the results generally mirror those obtained from GEA (Section 3.6). Accurate calculation of the strontium $\mathrm{K}_{\mathrm{d}} \mathrm{s}$ is hampered by the relatively high ICP

Table 3.6. Selected Metal Distribution Results in Actual 70\% 101-AW DSSF Waste

\begin{tabular}{|c|c|c|c|}
\hline Material & $\mathrm{Cr} \mathrm{K}_{\mathrm{d}}$ & $\operatorname{Sr} K_{d}$ & $\mathbf{Z r} \mathbf{K}_{\mathrm{d}}$ \\
\hline CS-100 & $9.39 \mathrm{E}+00$ & $9.88 \mathrm{E}+\infty 0$ & $8.37 \mathrm{E}+01$ \\
\hline R-F & $1.17 \mathrm{E}+02$ & $5.33 \mathrm{E}+01$ & $9.73 E+01$ \\
\hline SL-644 & $1.37 \mathrm{E}+02$ & $7.53 \mathrm{E}+01$ & $1.50 \mathrm{E}+02$ \\
\hline IE-910 & $--^{(a)}$ & $>1.91 \mathrm{E}+02$ & $2.88 \mathrm{E}+01$ \\
\hline IE-911 & - & $>2.20 \mathrm{E}+02$ & $-8.44 \mathrm{E}+01$ \\
\hline TIE-96 & - & $1.52 \mathrm{E}+02$ & $>6.76 \mathrm{E}+02$ \\
\hline $\mathrm{NaTi}$ & - & $>1.94 \mathrm{E}+02$ & $>6.08 \mathrm{E}+02$ \\
\hline
\end{tabular}


detection limit and data scatter. However, the following general trend is noted: (IE-911 $\approx$ IE-910 NaTi $>$ TIE-96 > SL-644 > R-F > CS-100). All of the materials except IE-911 remove zirconium to some extent (NaTI and TIE-96 removed zirconium to below the detection limit).

In addition to metals removal, certain materials appeared to generate some metals during the solid/liquid contact, which could possibly indicate material instability. The solution in contact with the zeolite TIE96 had three times the silicon that the blank had (341 vs 109 ppm Si). This result is not too surprising since many zeolites are known to be unstable in caustic solution. In addition, all of the inorganic materials (IE-910, IE-911, NaTi, and TIE-96) generated greater than detectable quantities of titanium after contact. Stability or instability of the organic resins (CS-100, R-F, and SL-644) cannot be ascertained from these data since Total Organic Carbon (TOC) or other organic analyses were not completed. These results do not necessarily indicate lack of stability or suggest that the inorganic materials should not be employed in similar radionuclide removal processes. Instead, addition chemical stability experiments should be devised using these results for guidance.

\subsection{Multiple Contact Distributions in Actual DSSF}

\subsubsection{Cesium Distribution}

A comparison of the overall DFs achieved during the two contact experiment is displayed in Table 3.7. A maximum DF of 421 for ${ }^{137} \mathrm{Cs}$ was obtained with the SL-644 material. This corresponds to a ${ }^{137} \mathrm{Cs}$ concentration of $0.46 \mathrm{Ci} \mathrm{m}^{-3}$ at $5 \mathrm{M}$ sodium. This is lower than the NRC Class A limit and the pretreatment level currently assumed in the TWRS process flowsheet (Orme 1995). The maximum DF for ${ }^{90} \mathrm{Sr}$ of 239 was obtained using the IE-911 material. Applying this DF to the feed concentration

Table 3.7. Cumulative Cesium and Strontium Decontamination Factors in Actual 70\% 101-AW DSSF Waste

\begin{tabular}{||l|c|c||}
\hline \multicolumn{1}{|c|}{ Material } & Cs DF & Sr DF \\
\hline CS-100 & $1.99 \mathrm{E}+00$ & $1.12 \mathrm{E}+00$ \\
\hline R-F & $4.21 \mathrm{E}+01$ & $2.53 \mathrm{E}+00$ \\
\hline SL-644 & $4.30 \mathrm{E}+02$ & $8.23 \mathrm{E}+00$ \\
\hline IE-910 & $2.84 \mathrm{E}+02$ & $9.45 \mathrm{E}+01$ \\
\hline IE-911 (38B) & $1.89 \mathrm{E}+02$ & $2.42 \mathrm{E}+02$ \\
\hline NaTi & $\mathrm{NA}^{(a)}$ & $\mathrm{NA}^{(\mathrm{a})}$ \\
\hline TIE-96 & $2.60 \mathrm{E}+00$ & $3.66 \mathrm{E}+01$ \\
\hline (a) Not applicable. & \\
\hline
\end{tabular}


of $0.16 \mu \mathrm{Ci} \mathrm{mL}^{-1}$ gives an effluent concentration of 6.7E-04 $\mathrm{Ci} \mathrm{m}^{-3}$, which is much lower than the NRC Class A limit of $0.04 \mathrm{Ci} \mathrm{m}^{-3}$. These DFs are a general reflection of the $\lambda$ values and are not an indication of the DFs that could be obtained in a column type.operation. For both cesium and strontium, it is likely that additional contacts with any of the materials would have provided additional decontamination.

\subsubsection{ICP Metals Distribution}

The multiple contact experiment provides a unique opportunity to investigate the removal of components other than cesium and/or strontium from the actual waste solution using ICP metals analysis. In this particular test, a large excess $(\sim 0.5 \mathrm{~g})$ of solid sorbent is contacted with the actual waste $(\sim 8 \mathrm{~mL})$ residue as described in Section 2.6.2. Due to the lower liquid-solid phase ratio, higher DFs are obtained for all removable species. The increased component removal results in more accurate batch distribution calculations due to the decreased analytical uncertainty.

The results of the multiple contact (high DF) experiment confirmed the trends observed during the first contact (Section 3.7) with respect to beryllium, chromium, strontium, and zirconium. In addition, the removal of calcium, iron, and nickel by certain ion exchange materials is also observed. Beryllium was removed by all materials except IE-911 (CS-100 > SL-644 > RF > IE-910 > TIE-96). Calcium was removed by all but the SL-644 and RF resins (IE-911 > TIE-96 > IE-910 > CS-100 > RF). Although the data are somewhat scattered, iron seems to be removed by all materials (CS-100 > IE-911 > RF > SL-644 > IE-910) except TIE-96, which appears to evolve iron. The organic ion exchange materials (SL$644>\mathrm{RF}>\mathrm{CS}-100$ ) remove chromium and nickel. As was previously noted, titanium is evolved by the inorganics, all materials remove a small amount of zinc, and all except IE-911 remove zirconium. These results are summarized in Table 3.8 .

Table 3.8. Metal Distribution Results from Second Contact in Actual 70\% 101-AW DSSF Waste

\begin{tabular}{|c|c|c|c|c|c|c|}
\hline Material & Be $\mathbf{K}_{d}$ & $\mathrm{Ca} \mathrm{K}_{\mathrm{d}}$ & Cr $K_{d}$ & $\mathrm{Fe} \mathrm{K}_{\mathrm{d}}$ & $\mathrm{Ni} \mathrm{\textrm {K } _ { \mathrm { d } }}$ & $\mathbf{Z r} \mathbf{K}_{\mathbf{d}}$ \\
\hline CS-100 & 50.8 & 7.7 & 4.6 & 71.5 & 20.9 & 153.8 \\
\hline R-F & 12.8 & - & 129.5 & 27.1 & 5.3 & 96.0 \\
\hline SL-644 & 30.7 & - & 270.8 & 16.1 & 24.1 & 96.8 \\
\hline IE-910 & $二_{\text {(a) }}$ & 17.2 & - & 6.5 & - & 22.5 \\
\hline IE-911 & 10.6 & 240.1 & - & 54.0 & - & -11.5 \\
\hline TIE-96 & 6.2 & 49.2 & - & -8.9 & - & 57.5 \\
\hline
\end{tabular}




\subsection{High Phase Ratio Distributions in Actual DSSF}

\subsubsection{Cesium and Strontium Distribution}

High phase ratio cesium and strontium batch tests were completed to investigate the effect that potential interferences have on the cesium and strontium $\lambda$ values. In this experiment, with more solution contacted per mass of exchanger, reduced removal of cesium could result if there is a significant amount of interfering components. Samples were submitted for GEA $\left({ }^{137} \mathrm{Cs}\right.$ and ${ }^{85} \mathrm{Sr}$ ) and ICP analysis (interferant metals). The ICP results have not been received, and therefore, information about potential interferences must be inferred from the cesium and strontium GEA data.

The cesium and strontium $\lambda$ values are compared in Tablè 3.9 for the high and average phase ratio tests. The cesium $\lambda$ values for the high phase ratio test are generally higher than results from the lower phase ratio. This tends to indicate a lack of interfering components, although even higher phase ratio tests would be required to dismiss this possibility. The results for strontium are mixed. Two strontium $\lambda$ values from the high phase ratio test higher than those of the average phase ratio test, and two are lower. These results do not provide any indication of interfering components, although again, higher phase ratio tests would be required to eliminate this possibility.

\subsubsection{ICP Metals Distribution}

At the higher phase ratio investigated in this test, there is a larger volume of actual waste per unit mass of exchanger during the contact. These conditions should act to emphasize the relative effect of metallic interferences (e.g., chromium, strontium, zirconium, etc.). The results are displayed in Table 3.10 and indicate that interferences probably are not important. The chromium and zirconium $\mathrm{K}_{\mathrm{d}}$ results are lower than those observed during the average phase ratio test (Table 3.6). The strontium $K_{d}$ results obtained by ICP are higher than those reported in Table 3.6 and in Table 3.9. These data demonstrate the limitations of the strontium ICP results. The ${ }^{85} \mathrm{Sr}$ counting data is thought to more accurate than the strontium ICP data.

Table 3.9. Comparison of Cesium and Strontium Distribution Results at Two Phase Ratios

\begin{tabular}{||c|c|c|c|c|c|c|c||}
\hline \multirow{2}{*}{$\begin{array}{c}\text { Ion } \\
\text { Exchange } \\
\text { Material }\end{array}$} & & \multicolumn{3}{|c|}{ High Phase Ratio } & \multicolumn{3}{c||}{ Average Phase Ratio } \\
\cline { 2 - 9 } & Na/Cs Ratio & $\begin{array}{c}\text { Phase Ratio } \\
\mathbf{m L ~ g}^{-1}\end{array}$ & $\operatorname{Cs} \lambda$ & Sr $\lambda$ & $\begin{array}{c}\text { Phase Ratio } \\
\text { mL } \mathbf{~ g}^{-1}\end{array}$ & Cs $\lambda$ & Sr $\lambda$ \\
\hline \hline R-F & $1.08 \mathrm{E}+05$ & 480 & 77 & 35 & 150 & 70 & 17 \\
\hline SL-644 & $1.55 \mathrm{E}+05$ & 480 & 120 & 18 & 150 & 130 & 20 \\
\hline IE-910 & $1.67 \mathrm{E}+05$ & 920 & 875 & 695 & 150 & 780 & 605 \\
\hline IE-911 & $1.09 \mathrm{E}+05$ & 885 & 900 & 900 & 150 & 850 & 1000 \\
\hline
\end{tabular}


Table 3.10. High Phase Ratio Metal Distribution Results in Actual 70\% 101-AW DSSF Waste

\begin{tabular}{||l|c|c|c|c||}
\hline Material & Ca K $_{\delta}$ & Cr K $_{d}$ & Sr K & Zr K \\
\hline \hline R-F & $-{ }^{\text {(a) }}$ & 63.1 & 151.2 & 58.9 \\
\hline SL-644 & -- & 64.7 & 131.4 & 67.6 \\
\hline IE-910 & -- & - & $>2770$ & - \\
\hline IE-911 & 113.6 & - & $>3044$ & -212.2 \\
\hline (a) No statistically significant metals removal. \\
\hline
\end{tabular}





\subsection{Conclusions}

Based on the results of the batch testing with simulants and actual waste, the following observations and conclusions are made:

\section{Processing considerations}

- During the two contact tests, a maximum DF of 421 for ${ }^{137} \mathrm{Cs}$ was obtained with the SL-644 material. This corresponds to a ${ }^{137} \mathrm{Cs}$ concentration of $0.46 \mathrm{Ci} \mathrm{m}^{-3}$ at $5 \mathrm{M} \mathrm{Na}$, which is lower than the NRC Class A limit of $1 \mathrm{Ci} \mathrm{m}^{-3}$. Maximum ${ }^{90} \mathrm{Sr} \mathrm{DF}$ (239) was obtained using the IE-911 material. This corresponds to an effluent concentration of $6.7 \mathrm{E}-04 \mathrm{Ci} \mathrm{m}^{-3}$, which is significantly lower than the NRC Class A limit of $0.04 \mathrm{Ci} \mathrm{m}^{-3}$. These DFs are a general reflection of the $\lambda$ values and are not indicative of the DFs that could be obtained in a column type operation. It is likely that additional contacts with any material would have provided additional cesium and strontium decontamination.

- Comparison of cesium and strontium $\lambda$ values from batch contacts at different phase ratios does not indicate the presence of interfering species that might foul the exchanger surface or exchange sites.

\section{Cesium equilibrium results}

- In general, there was agreement between the cesium $\lambda$ results obtained with the simulated and actual wastes. However, for all of the materials the actual waste results were lower than those obtained in the simulant. At feed conditions ( $5 \mathrm{M}$ Na and $\mathrm{Na} / \mathrm{Cs}=78,000)$, the difference between the simulant and actual waste cesium $\lambda$ values was $-4 \%,-50 \%,-14 \%,-35 \%,-21 \%$, and $-24 \%$, for CS-100, R-F, SL-644, IE-910, IE-911, and TIE-96, respectively.

- The general order of cesium $\lambda$ values is: IE-910 $\approx \mathbb{I E}-911$ (08 and 38B) $>R-F$, Superlig $644>$ TIE-96 > CS-100.

- All forms of the CST sorbent (powdered IE-910 and engineered IE-911) demonstrate high affinity for cesium and strontium in the actual and simulated waste solutions. The cesium $\lambda$ for the IE-911 (38B) material was nearly identical to that of the IE-910 during the actual and simulant waste tests at $5 \underline{\mathrm{M} \mathrm{Na}}$ and was only $20 \%$ to $30 \%$ lower during the simulant testing at low ionic strength $(0.2 \underline{\mathrm{M} \mathrm{Na}})$. Evidently, fabrication into an engineered form did not severely impact the equilibrium cesium batch distribution for the CSTs. 
- Since the CST materials are nonregenerable and must be used on a once-through basis and possibly vitrified, it may be more appropriate to evaluate these materials on a mass $\left(K_{d}\right)$ rather than a unit volume basis. Depending on the conditions chosen, the $\mathrm{K}_{\mathrm{d}} \mathrm{s}$ for the IE-911 (38B) material ranged from about $70-80 \%$ of those for the IE-910 at $5 \underline{\mathrm{M}} \mathrm{Na}$, while the $\mathrm{K}_{\mathrm{d}} \mathrm{s}$ for the IE-911 (08) material were approximately $80 \%$ that of the IE- 910 material.

- Based on the simulant results, a 25 -fold dilution of the waste from $5 \underline{\mathrm{M}} \mathrm{Na}$ to $0.2 \mathrm{M} \mathrm{Na}$ increases the CST cesium loading 12-14\%, doubles the loading on the TIE-96, and decreases the cesium loading $40-45 \%$ for the organic exchangers. The process implication is that for inorganic materials, the amount of exchanger required can be minimized by processing dilute streams (e.g., before evaporative concentration of the waste). Conversely, if organic exchangers are used, the number of load/elute cycles can be minimized by processing concentrated waste streams.

\section{Strontium equilibrium behavior}

- All of the materials have an affinity for strontium, with NaTi providing the greatest removal followed by IE-911, IE-910, and TIE-96. The organic exchangers exhibited relatively low affinities (SL-644 > R-F > CS-100) and would not be useful for strontium removal.

- For every ion exchange material, the strontium $\lambda$ results were much lower in the actual waste experiment than those obtained during the simulant tests. This is most likely due to reduced strontium levels in the simulant compared to the actual waste and the presence of organic materials in the actual waste that were not present in the simulant. The exact nature of these organics is not known but they are generally complexant materials that would react with the strontium to form neutral or anionic complexants and thereby reduce the extent to which cation exchange takes place.

- The CST and NaTi materials exhibited very large strontium $\lambda$ values $(>1 E+06)$ for the simulated waste. The organic exchangers had much lower strontium $\lambda$ values, which ranged from 18-38. During actual waste testing, the calculated strontium $\lambda$ values for the IE-911 (38B) and NaTi materials were nearly identical (ca. 1000). Surprisingly, the value for IE-910 was about 500, less than the engineered IE-911. The organic exchangers all exhibited much lower strontium $\lambda$ values, ranging from about 3 for CS-100 to 20 for the R-F and SuperLig materials.

- Over the range of conditions investigated, the concentration of cesium generally had little effect on strontium $\lambda$. This is not surprising since both cesium and strontium are present in low concentrations and generally do not compete for the same exchange sites. This means that the equilibrium system can be approximated as if it is two binary ion exchange interactions. 


\section{Other components}

- The removal of chromium by the organic resins (SL-644 $>\mathrm{R}-\mathrm{F}>\mathrm{CS}-100$ ) and zirconium by all of the exchangers except IE-911 (NaTi $\approx$ TIE-96 > SL-644 > R-F > CS-100 > IE-910) suggests that additional column loading and elution experiments will be needed to determine the quantity of these metals in the process solutions. 



\subsection{References}

Anthony, R. G., R. G. Dosch, D. Gu, and C. V. Philip. 1994. "Use of Silico-Titanates for Removing Cesium and Strontium from Defense Waste, "I\&EC Research, 33 (11), 2702-5.

Anthony, R. G., C. V. Philip, and R. G. Dosch. 1993. "Selective Adsorption and Ion Exchange of Metal Cations and Anions with Silico-Titanates and Layered Titanates," Waste Management, 13, 503.

Bibler, J. P. 1991. A Comparison of Duolite ${ }^{T M}$ CS-100 and SRS Resorcinol/Formaldehyde Ion Exchange Resins with Three High-Level Waste Simulants Before and After $\gamma$-Irradiation, WSRC-RP-91-1221, Letter Report for the Savannah River Laboratory.

Bibler, J. P. 1994. Year-End Report for UST: Cesium Extraction Testing Project DOEDT\&E TTP No. SRI-03-20-01 (U), WSRC-RP-94-146, Westinghouse Savannah River Company, Aiken South Carolina.

Bibler, J. P., R. M. Wallace, and L. A. Bray. 1989. "Testing A New Cesium-Specific Ion Exchange Resin For Decontamination of Alkaline-High Activity Waste." In Proceedings of the Symposium on Waste Management '90, February 25 - March 1, 1990. Tucson, Arizona.

Bibler, N. E. and C. L. Crawford. 1994. An Investigation of the Radiolytic Stability of a ResorcinolFormaldehyde Ion Exchange Resin, WSRC-RP-94-148, Westinghouse Savannah River Company, Aiken South Carolina.

Bray, L. A., K. J. Carson, and R. J. Elovich. 1990. Cesium Recovery Using Savannah River Laboratory Resorcinol-Formaldehyde Ion Exchange Resin. PNL-7273, Pacific Northwest National Laboratory, Richland, Washington.

Bray, L. A., K. J. Carson, and R. J. Elovich. 1993. Initial Evaluation of Sandia National Laboratory Prepared Crystalline Silico-Titanates for the Recovery of Cesium. PNL-8847, Pacific Northwest National Laboratory, Richland, Washington.

Bray, L. A., and F. T. Hara. 1991. "Use of Titanium-Treated Zeolite for Plutonium, Strontium, and Cesium Removal from West Valley Alkaline Wastes and Sludge Wash Waters." In First Hanford Separations Science Workshop. PNL-SA-19697S, pp. II.87-II.91. Pacific Northwest National Laboratory, Richland, Washington.

Bray, L. A., L. K. Holton, T. R. Meyers, G. M. Richardson, and B. M. Wise. 1984. Experimental Data Developed to Support the Selection of a Treatment Process for West Valley Alkaline Supernatant. PNL-4969, Pacific Northwest National Laboratory, Richland, Washington. 
Brown, G. N., L. A. Bray, C. D. Carlson, K. J. Carson, J. R. DesChane, R. J. Elovich, and P. K. Tanaka. 1994. Initial Evaluation of Processes Capable of Removing Strontium from Complexant-Containing Alkaline Waste Supernate. FY 1994 Final Report. TWRSPP-94-097, Pacific Northwest Laboratory, Richland, Washington.

Brown, G. N., S. R. Adami, L. A. Bray, S. A. Bryan, C. D. Carlson, K. J. Carson, J. R. DesChane, R. J. Elovich, S. J. Forbes, J. A. Franz, J. C. Linehan, W. J. Shaw, P. K. Tanaka, and M. R. Telander. 1995a. Chemical and Radiation Stability of SuperLig ${ }^{\circledR}$ 644, Resorcinol-Formaldehyde, and CS-100 Cesium Ion Exchange Materials. PNL-10772, Pacific Northwest National Laboratory, Richland, Washington.

Brown, G. N., L. A. Bray, R. J. Elovich. 1995b. Evaluation and Comparison of SuperLig ${ }^{\circledR} 644$, Resorcinol-Formaldehyde and CS-100 Ion Exchange Materials for the Removal of Cesium from Simulated Alkaline-Supernate. PNL-10486, Pacific Northwest National Laboratory, Richland, Washington.

Brown, G. N., J. R. Bontha, C. D. Carlson, K. J. Carson, J. R. DesChane, R. J. Elovich, D. E. Kurath, P. K. Tanaka, D. W. Edmonson, D. L. Herting, and J. R. Smith. 1995c. Ion Exchange Removal of Cesium from Simulated and Actual Supernate from Hanford Tanks 241-SY-101 and 241-SY-103. PNL-10792, Pacific Northwest National Laboratory, Richland, Washington.

Dosch, R. G., N. E. Brown, H. P. Stephens, and R. G. Anthony. 1993. "Treatment of Liquid Nuclear Wastes with Advanced Forms of Titanate Ion Exchangers," Waste Management '93,. 1751, Tucson, Arizona.

Eager, K. M., D. L. Penwell, and B. J. Knutson. 1994. Preliminary Flowsheet: Ion Exchange Process for Separation of Cesium from Hanford Tank Waste Using Duolite CS-100 Resin.

WHC-SD-WM-TI-667 Rev. 0, Westinghouse Hanford Company, Richland, Washington.

Klavetter, E. A., N. E. Brown, D. E. Trudell, R. G. Anthony, D. Gu, and C. Thibaud-Erkey. 1994. "Ion-Exchange Performance of Crystalline Silicotitanates for Cesium Removal from Hanford Tank Waste Simulants," Waste Management '94, 709; Tucson, Arizona.

Kurath, D. E., L. A. Bray, K. P. Brooks, G. N. Brown, S. A. Bryan, C. D. Carlson, K. J. Carson, J. R. DesChane, R. J. Elovich and A. Y. Kim. 19.94. Experimental Data and Analysis to Support the Design of an Ion Exchange Process for the Treatment of Hanford Tank Waste Supernatant Liquids. PNL-10187, Pacific Northwest National Laboratory, Richland, Washington.

Marsh, S. F., Z. V. Svitra, and S. M. Bowen. 1994. Distributions of 15 Elements on 58 Absorbers from Simulated Hanford Double-Shell Slurry Feed (DSSF). LA-12863, Los Alamos National Laboratory, Los Alamos, New Mexico. 
Marsh, S. F., Z. V. Svitra, and S. M. Bowen. 1995. Effects of Soluble Organic Complexants and Their Degradation Products on the Removal of Selected Radionuclides from High-Level Waste. LA-13000, Los Alamos National Laboratory, Los Alamos, New Mexico.

Orme R. M. 1995. TWRS Process Flow Sheet. WHC-SD-WM-TI-613, Rev 1. Westinghouse Hanford Company, Richland Washington.

Orth, R. J. and D. E. Kurath. September, 1993. Review and Assessment of Technologies for the Separation of Strontium from Alkaline and Acidic Media. PNL-9053, Pacific Northwest Laboratory, Richland, Washington.

Penwell, D. L., K. M. Eager, and B. J. Knutson. 1994. Preliminary Flowsheet: Ion Exchange Process for Separation of Cesium from Hanford Tank Waste Using Resorcinol-Formaldehyde Resin. WHC-SD-WM-TI-638 Rev. 0, Westinghouse Hanford Company, Richland, Washington.

Samuelson, O. 1953. Ion Exchangers in Analytical Chemistry. John Wiley and Sons, New York.

Samuelson, O. 1963. Ion Exchanger Separations in Analytical Chemistry. John Wiley and Sons, New York.

Svitra, Z. V., S. F. Marsh, and S. M. Bowen. 1994. Distributions of 12 Elements on 64 Absorbers from Simulated Hanford Neutralized Current Acid Waste (NCAW). LA-12889, Los Alamos National Laboratory, Los Alamos, New Mexico.

Zheng, Z., D. Gu, R. G. Anthony, and E. A. Klavetter. 1995. "Estimation of Cesium Ion Exchange Distribution Coefficient for Concentrated Electrolytic Solutions When Using Crystalline Silicotitanates," I\&EC Research, 34(6), 2142-2147. 



\section{Appendix A}

\section{Test Instructions for DSSF Waste Preparation}





\section{Attachment A: Test Instructions for DSSF Waste Preparation}

Objective: To prepare a synthetic stock DSSF test feed (diluted to $5 \underline{\mathrm{M}}$ sodium) based on the analytical results of actual Hanford DSSF.

1. Test Solution Make-Up, Synthetic 101-AW DSSF Stock Solution

\begin{tabular}{|c|c|c|c|c|c|c|}
\hline Component & $\underline{F W}, g$ & Molarity & $\mathrm{g} / \mathrm{L}$ & $\mathrm{g} / 2 \mathrm{~L}$ & Weight & Date \\
\hline $\mathrm{KOH}$ & 56.11 & 0.6650 & 37.31 & 74.63 & & \\
\hline $\mathrm{Na}_{2} \mathrm{SO}_{4}$ & 142.05 & 0.0152 & 2.15 & 4.31 & & \\
\hline $\mathrm{Na}_{2} \mathrm{HPO}_{4} \cdot 7 \mathrm{H}_{2} \mathrm{O}$ & 268.07 & 0.0245 & 6.57 & 13.14 & & \\
\hline $\mathrm{NaOH}$ & 40.00 & 5.1567 & 206.27 & 412.53 & & \\
\hline $\mathrm{Al}\left(\mathrm{NO}_{3}\right)_{3} \cdot 9 \mathrm{H}_{2} \mathrm{O}$ & 375.15 & 0.6953 & 260.85 & 521.71 & & \\
\hline $\mathrm{Na}_{2} \mathrm{CO}_{3}$ & 105.99 & 0.1960 & 20.77 & 41.55 & & \\
\hline $\mathrm{NaCl}$ & 58.45 & 0.0910 & 5.32 & 10.64 & & \\
\hline $\mathrm{NaF}$ & 41.99 & 0.0607 & 2.55 & 5.10 & & \\
\hline $\mathrm{NaNO}_{2}$ & 69.00 & 1.2250 & 84.53 & 169.05 & & \\
\hline $\mathrm{Ba}\left(\mathrm{NO}_{3}\right)_{2}$ & 261.35 & $8.28 \mathrm{E}-07$ & $2.16 \mathrm{E}-04$ & 4.33E-04 & & \\
\hline $\mathrm{Ca}\left(\mathrm{NO}_{3}\right)_{2} \bullet 4 \mathrm{H}_{2} \mathrm{O}$ & 236.18 & $3.62 \mathrm{E}-04$ & $8.54 \mathrm{E}-02$ & $1.71 \mathrm{E}-01$ & & \\
\hline $\mathrm{Sr}\left(\mathrm{NO}_{3}\right)_{2}$ & 211.64 & $1.00 \mathrm{E}-07$ & $2.12 \mathrm{E}-05$ & $4.25 \mathrm{E}-05$ & & \\
\hline
\end{tabular}

After preparation the solution should have the following composition:

$\begin{array}{lcc}\text { Species } & \begin{array}{c}\text { Stock } \\ \text { 101-AW, M }\end{array} & \begin{array}{c}\text { Diluted } \\ 101-\mathrm{AW}, \mathrm{M}\end{array} \\ \mathrm{Na} & \begin{array}{l}\text { Na } \\ \mathrm{Al}\end{array} & \\ \mathrm{Ba} & 6.05 \mathrm{E}-01 & 4.00 \mathrm{E}+00 \\ \mathrm{Ca} & 8.28 \mathrm{E}-07 & 5.97 \mathrm{E}-01 \\ \mathrm{~K} & 3.62 \mathrm{E}-04 & 2.41 \mathrm{E}-04 \\ \mathrm{Sr} & 6.65 \mathrm{E}-01 & 4.75 \mathrm{E}-01 \\ \mathrm{SO}{ }_{4} & 1.00 \mathrm{E}-07 & 7.14 \mathrm{E}-08 \\ \mathrm{OH} & 1.52 \mathrm{E}-02 & 1.26 \mathrm{E}-02 \\ \mathrm{OH} \text { (Free) } & 5.82 \mathrm{E}+00 & 4.16 \mathrm{E}+00 \\ \mathrm{Theoretical} \mathrm{pH} & 3.04 \mathrm{E}+00 & 2.17 \mathrm{E}+00 \\ \mathrm{Cl} & 1.51 \mathrm{E}+01 & 1.48 \mathrm{E}+01 \\ \mathrm{CO}_{3} & 9.10 \mathrm{E}-02 & 6.50 \mathrm{E}-02 \\ \mathrm{~F} & 1.96 \mathrm{E}-01 & 1.40 \mathrm{E}-01 \\ \mathrm{NO}_{2} & 6.07 \mathrm{E}-02 & 4.33 \mathrm{E}-02 \\ \mathrm{NO}_{3} & 1.23 \mathrm{E}+00 & 9.40 \mathrm{E}-01 \\ \mathrm{PO}_{4} & 2.09 \mathrm{E}+00 & 1.49 \mathrm{E}+00 \\ \mathrm{Cs} & 2.45 \mathrm{E}-02 & 1.75 \mathrm{E}-02 \\ & \text { Variable } & \text { Variable }\end{array}$



Appendix B

Cesium and Strontium $\lambda$ Values for the Simulant Experiments 



\begin{tabular}{|c|c|c|c|c|c|c|c|c|c|c|c|c|c|c|c|c|}
\hline \multicolumn{4}{|c|}{ Waste-DSSF composite (70\% 101-AW, $20 \%$ 10\%) } & \multicolumn{2}{|c|}{ Temperature $=25 \mathrm{C}$} & & & & & & & & & & & \\
\hline & & & & & & & & & & & & & & & & \\
\hline DNumber & AEUC & AEUC-1 & AEVC & AEVC-1 & $\overline{A E W C}$ & AEWC-1 & AEXC & AEXC-1 & AEYC & AEYC-1 & AEZC & AEZC-1 & I & 2 & 61 & 62 \\
\hline Material & CST: & IE-910 & AS NaTi: & $8104-170$ & Super! & 9644 & Cs & 00 & R-F: $\mathrm{E}$ & SC210 & Zeolite: & TIE-96 & IE-911, ( & $3671-08)$ & IE-911, ( & 739-388) \\
\hline Na], Mol. & $2.000 \mathrm{E}-01$ & $2.000 E-01$ & $2.000 \mathrm{E}-01$ & $2.000 E-01$ & $2.000 E-01$ & $2.000 \mathrm{E}-01$ & $2.000 \mathrm{E}-01$ & $2.000 \mathrm{E}-01$ & $2.000 \mathrm{E}-01$ & $2.000 \mathrm{E}-01$ & $2.000 E-01$ & $2.000 \mathrm{E} \cdot 01$ & $2.000 E-01$ & $2.000 E-01$ & $2.000 \mathrm{E}-01$ & $2.000 E-01$ \\
\hline F Factor & $9.680 E-01$ & \begin{tabular}{|l|}
$9.680 \mathrm{E}-01$ \\
\end{tabular} & $9.764 \mathrm{E}-01$ & $9.764 E-01$ & $9.751 E-01$ & $9.751 \mathrm{E}-01$ & $6.148 \mathrm{E}-01$ & $6.148 \mathrm{E}-01$ & $8.070 \mathrm{E}-01$ & $8.070 E-01$ & $8.338 \mathrm{E}-01$ & $8.338 \mathrm{E}-01$ & $8.990 E-01$ & $8.990 \mathrm{E}-01$ & $8.870 \mathrm{E}-01$ & $8.870 \mathrm{E}-01$ \\
\hline $\mathrm{Na} / \mathrm{Cs}$ Start & $5.000 \mathrm{E}+01$ & $5.000 \mathrm{E}+01$ & $5.000 E+01$ & $5.000 E+01$ & $5.000 E+01$ & $5.000 \mathrm{E}+01$ & $5.000 \mathrm{E}+01$ & $5.000 E+01$ & $5.000 \mathrm{E}+01$ & $5.000 \mathrm{E}+01$ & $5.000 \mathrm{E}+01$ & $5.000 \mathrm{E}+01$ & $5.000 E+01$ & $5.000 E+01$ & $5.000 E+01$ & $E+01$ \\
\hline Na/Cs Final & $4.348 E+02$ & $4.489 E+02$ & $5.161 E+01$ & $5.167 \mathrm{E}+01$ & $1.006 E+02$ & $9.798 E+01$ & $7.473 E+01$ & $7.492 E+01$ & $8.590 E+01$ & $8.403 E+01$ & $1.425 E+02$ & $1.441 E+02$ & $5.022 E+02$ & $6.387 E+02$ & $2.471 E+02$ & $2.681 E+02$ \\
\hline $\mathrm{Cs} \mathrm{Kd}, \mathrm{mL} / \mathrm{g}$ & $1.857 \mathrm{E}+03$ & $1.923 E+03$ & $7.328 E+00$ & $7.659 E+00$ & $2.305 E+02$ & $2.215 E+02$ & $1.813 E+02$ & $1.815 E+02$ & $2.009 E+02$ & $1.918 E+02$ & $4.975 E+02$ & $5.028 E+02$ & $1.571 E+03$ & $2.081 E+03$ & $6.735 \mathrm{E}+02$ & $8 E+02$ \\
\hline Density, $\mathrm{g} / \mathrm{mL}$ & $7.738 E-01$ & $7.738 \mathrm{E}-01$ & $5.812 E-01$ & $5.812 \mathrm{E}-01$ & $2.238 \mathrm{E}-01$ & $2.238 \mathrm{E}-01$ & $2.434 \mathrm{E}-01$ & $2.434 \mathrm{E}-01$ & $3.044 \mathrm{E}-01$ & $3.044 E-01$ & $7.672 \mathrm{E} \cdot 01$ & $7,672 E-01$ & $8.999 \mathrm{E}-01$ & \begin{tabular}{|l|}
$8.999 E-01$ \\
\end{tabular} & $1.126 E+00$ & $1.126 E+00$ \\
\hline Cs Lambda & $1.437 E+03$ & $1.488 E+03$ & $4.259 \mathrm{E}+00$ & $4.452 E+00$ & $5.158 E+01$ & $4.957 \mathrm{E}+01$ & $4.413 E+01$ & $4.419 E+01$ & $6.114 E+01$ & $5.839 \mathrm{E}+01$ & $3.817 \mathrm{E}+02$ & $E+02$ & +03 & $E+03$ & $E+02$ & +02 \\
\hline & & & & & & & & & & & & & & & & \\
\hline ID Number & FUC & AFUC-1 & AFVC & AFVC-1 & AFWC & AFW & AFXC & AFXC-1 & AFYC & AFYC-1 & AFZC & AFZC-1 & 3 & 4 & 63 & 64 \\
\hline Material & CST: & $E-910$ & AS NaTi: & $8104-170$ & Superl & 9644 & $\overline{C s}$ & 100 & R-F: $\mathrm{E}$ & $\overline{\mathrm{SC} 210}$ & Zeolite: & TIE-96 & IE-911, I & $3671-08)$ & IE-911, ( & $7739-38 \mathrm{~B})$ \\
\hline [Na], Mol. & $2.000 \mathrm{E} \cdot 01$ & $2.000 \mathrm{E}-01$ & $2.000 E-01$ & $2.000 E-01$ & $2.000 E-01$ & $2.000 \mathrm{E}-01$ & $2.000 \mathrm{E}-01$ & $2.000 \mathrm{E}-01$ & $2.000 \mathrm{E} \cdot 01$ & $2.000 E-01$ & $2.000 \mathrm{E} \cdot 01$ & $2.000 \mathrm{E}-01$ & $2.000 \mathrm{E}-01$ & $2.000 \mathrm{E}-01$ & 2.000E-01 & $2.000 E-01$ \\
\hline F Factor & $9.680 \mathrm{E} \cdot 01$ & $9.680 \mathrm{E}-01$ & $9.764 E-01$ & $9.764 \mathrm{E}-01$ & $9.751 \mathrm{E}-01$ & $9.751 \mathrm{E}-01$ & $6.148 E-01$ & $6.148 \mathrm{E} \cdot 01$ & $8.070 E-01$ & $8.070 E-01$ & $8.338 \mathrm{E}-01$ & $8.338 \mathrm{E}-01$ & $8.990 \mathrm{E}-01$ & 8.990E.01 & $8.870 \mathrm{E}-01$ & $8.870 \mathrm{E}-01$ \\
\hline Na/Cs Start & $5.000 E+02$ & $5.000 E+02$ & $5.000 E+02$ & $5.000 \mathrm{E}+02$ & $5.000 E+02$ & $5.000 E+02$ & $5.000 E+02$ & $5.000 \varepsilon+02$ & $5.000 E+02$ & $5.000 E+02$ & $5.000 E+02$ & $5.000 E+02$ & $5.000 E+02$ & $5.000 E+02$ & $5.000 E+02$ & $5.000 E+02$ \\
\hline $\mathrm{Na} / \mathrm{Cs}$ Final & $5.850 E+04$ & $5.139 E+04$ & $5.235 \mathrm{E}+02$ & $5.232 E+02$ & $7.538 E+03$ & $7.724 E+03$ & $1.128 E+03$ & $1.140 E+03$ & $3.874 E+03$ & $\mathrm{E}+03$ & $2.679 E+03$ & $2.678 E+03$ & $4.717 E+04$ & $4.622 E+04$ & $3.679 E+04$ & $3.871 \mathrm{E}+04$ \\
\hline $\mathrm{Cs} \mathrm{Kd} \mathrm{mUg}$ & \begin{tabular}{|c|c|}
$8.063 E+04$ \\
\end{tabular} & $4.778 E+04$ & $1.090 \mathrm{E}+01$ & $1.053 E+01$ & $3.492 E+03$ & $3.575 E+03$ & $4.581 E+02$ & $4.675 E+02$ & $1.930 \mathrm{E}+03$ & $1.838 \mathrm{E}+03$ & $1.194 E+03$ & $1.193 E+03$ & $2.997 \mathrm{E}+04$ & $2.871 \mathrm{E}+04$ & $1.919 E+04$ & $2.076 \mathrm{E}+04$ \\
\hline Density, g/mL & \begin{tabular}{|c|}
$7.738 \mathrm{E}-01$ \\
\end{tabular} & $7.738 \mathrm{E}-01$ & $5.812 \mathrm{E} \cdot 01$ & $5.812 \mathrm{E}-01$ & $2.238 \mathrm{E}-01$ & $2.238 E-01$ & $2.434 \mathrm{E}-01$ & $2.434 \mathrm{E}-01$ & $3.044 \mathrm{E}-01$ & E-01 & $7.672 \mathrm{E}-01$ & 7.672E-01 & \begin{tabular}{|l|}
$8.999 E-01$ \\
\end{tabular} & \begin{tabular}{|l|}
$8.999 \mathrm{E}-01$ \\
\end{tabular} & $1.126 E+00$ & $1.126 E+00$ \\
\hline Cs Lambda & $6.239 E+04$ & $3.697 E+04$ & $6.333 E+00$ & $6.120 E+00$ & $7.814 E+02$ & $8.001 E+02$ & $1.115 E+02$ & $1.138 \mathrm{E}+02$ & $5.876 E+02$ & $5.596 \mathrm{E}+02$ & $9.164 E+02$ & $9.151 E+02$ & \begin{tabular}{|l}
$2.697 E+04$ \\
\end{tabular} & $2.583 E+04$ & $2.160 E+04$ & $2.336 E+04$ \\
\hline & & & & & & & & & & & & & & & & \\
\hline ID Number & AGUC & AGUC-1 & GVC & AGVC-1 & $\overline{A G W C}$ & AGWC-1 & AGXC & AGXC-1 & AGYC & AGYC-1 & AGZC & AGZC-1 & 5 & 6 & 65 & 66 \\
\hline Material & CST: & IE-910 & AS NaT: & $8104-170$ & Super & $\lg 644$ & $\overline{C s}$ & 100 & R-F: E & SC210 & Zeolite: & TIE-96 & TE-911, & 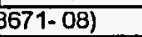 & IE-911, I & 388) \\
\hline [Na], Mol. & $2.000 E \cdot 01$ & \begin{tabular}{|l|}
$2.000 E-01$ \\
\end{tabular} & $2.000 E=01$ & $2.000 \mathrm{E}-01$ & $2.000 \mathrm{E}-01$ & 2,000 & $2.000 \mathrm{E}-01$ & $2.000 \mathrm{E}-01$ & $2.000 \mathrm{E}-01$ & $2.000 \mathrm{E} \cdot 01$ & $2.000 \mathrm{E} \cdot 01$ & \begin{tabular}{|l|}
$2.000 \mathrm{E}-01$ \\
\end{tabular} & $2.000 \mathrm{E}-01$ & $2.000 \mathrm{E}-01$ & $2.000 \mathrm{E}-01$ & $2.000 \mathrm{E}-01$ \\
\hline FFactor & $9.680 \mathrm{E}-01$ & $9.680 \mathrm{E}-01$ & $9.764 \mathrm{E}-01$ & $9.764 \mathrm{E}-01$ & $9.751 \mathrm{E}-01$ & $9.751 \mathrm{E}-01$ & $6.148 \mathrm{E}-01$ & $6.148 \mathrm{E}-01$ & $8.070 E-01$ & $8.070 \mathrm{E}-01$ & $8.338 \mathrm{E}-01$ & \begin{tabular}{|c|}
$8.338 \mathrm{E}-01$ \\
\end{tabular} & $8.990 \mathrm{E}-01$ & \begin{tabular}{|l|}
$8.990 E-01$ \\
\end{tabular} & $8.870 \mathrm{E}-01$ & $8.870 \mathrm{E}-01$ \\
\hline $\mathrm{Na} / \mathrm{Cs}$ Start & $5.000 E+03$ & $5,000 E+03$ & $5.000 \mathrm{E}+03$ & $5.000 \mathrm{E}+03$ & $5.000 E+03$ & $5.000 \mathrm{E}+03$ & $5.000 \mathrm{E}+03$ & $5.000 E+03$ & $5.000 E+03$ & $\bar{E}+03$ & $5.000 \mathrm{E}+03$ & \begin{tabular}{|l}
$.000 E+03$ \\
\end{tabular} & $5.000 E+03$ & $5.000 E+03$ & $5.000 E+03$ & $5.000 \mathrm{E}+03$ \\
\hline Na/Cs Final & $5.287 \mathrm{E}+05$ & $4.348 E+02$ & $4.348 E+02$ & $4.348 E+02$ & $4.348 E+02$ & $4.348 E+02$ & $4.348 E+02$ & +02 & $4.348 E+02$ & $4.348 E+02$ & $4.348 E+02$ & $4.348 E+02$ & $4.502 \mathrm{E}+05$ & $4.718 E+05$ & $4.120 E+05$ & $3.263 E+05$ \\
\hline $\mathrm{CsKd}, \mathrm{mLg}$ & $5.710 E+04$ & $6.157 \mathrm{E}+04$ & $9.962 E+00$ & $9.773 E+00$ & $9.853 E+03$ & $9.852 E+03$ & $8.305 E+02$ & $E+02$ & $6.148 E+03$ & $6.441 E+03$ & $1.350 E+03$ & $1.355 E+03$ & $3.116 E+04$ & $3.443 E+04$ & $2.462 E+04$ & $1.663 E+04$ \\
\hline$I \mathrm{~mL}$ & \begin{tabular}{|l|}
$7.738 \mathrm{E}-01$ \\
\end{tabular} & $7.738 \mathrm{E}-01$ & $5.812 \mathrm{E}-01$ & $5.812 \mathrm{E}-01$ & $2.238 \mathrm{E}-01$ & $2.238 \mathrm{E}-01$ & $2.434 E-01$ & $E-01$ & $3.044 E-01$ & $3.044 \mathrm{E}-01$ & $7.672 \mathrm{E}-01$ & \begin{tabular}{|c|}
$7.672 \mathrm{E}-01$ \\
\end{tabular} & $\begin{array}{l}8.999 \mathrm{E}-01 \\
\end{array}$ & \begin{tabular}{|l|}
$8.999 \mathrm{E} \cdot 01$ \\
\end{tabular} & $1.126 \mathrm{E}+00$ & $1.126 E+00$ \\
\hline Cs Lambda & $4.418 \mathrm{E}+04$ & $4.764 E+04$ & $5.790 E+00$ & $5.680 E+00$ & $2.205 E+03$ & $2.205 E+03$ & $2.021 E+02$ & $2.076 E+02$ & $1.872 \mathrm{E}+03$ & $1.961 E+03$ & $1.035 \mathrm{E}+03$ & $1.040 \mathrm{E}+03$ & $2.804 E+04$ & $3.098 E+04$ & $2.772 E+04$ & $1.871 E+04$ \\
\hline & & & & & & & & & & & & & & & & \\
\hline mber & AHUC & AHUC-1 & AHVC & AHVC-1 & $\begin{array}{l}\text { AHWC } \\
\text { Super }\end{array}$ & AHWC-1 & $\frac{\mathrm{AHXC}}{\mathrm{Cs}}$ & AHXC-1 & AHYC & $\begin{array}{l}\text { AHYC-1 } \\
\text { SC210 }\end{array}$ & $\frac{\text { AHZC }}{\text { Zeolite: }}$ & $\frac{\text { AHZC-1 }}{\text { TIE-96 }}$ & $\frac{7}{1 E-911 .}$ & 8 & 67 & 68 \\
\hline Material & CST: & E-910 & AS NaTI: & $8104-170$ & Super & $\frac{\lg 644}{2000}$ & $\frac{\mathrm{Cs}}{01}$ & $\frac{100}{20}$ & $\begin{array}{r}\text { R-F: } \\
2000 \mathrm{~F}-01\end{array}$ & $\frac{S C 210}{2000 E-01}$ & \begin{tabular}{|r|} 
Zeolite: \\
$2.000 \mathrm{E}-01$
\end{tabular} & $\begin{array}{l}\text { |1IE-96 } \\
2.000 E-01\end{array}$ & \begin{tabular}{|r|} 
IE-911, \\
$2.000 E-01$
\end{tabular} & $8671-08)$ & $\frac{\text { IE-911, }}{2000=.01}$ & $\frac{739 \cdot 38 \mathrm{~B})}{2000 \mathrm{E} \cdot 01}$ \\
\hline [Na], Mol, & \begin{tabular}{|l|}
$2.000 \mathrm{E}-01$ \\
\end{tabular} & $2.000 E-01$ & $2.000 E-01$ & 2.000E-01 & $\frac{2.000 \mathrm{E}-01}{9.751 \mathrm{E}-01}$ & $\frac{2.00}{9.75}$ & $\frac{2.000 \mathrm{E}-01}{6.148 \mathrm{E}-01}$ & $\frac{2.01}{6.1}$ & $\frac{2.000 E-01}{8.070 E-01}$ & JE-01 & E-01 & \begin{tabular}{|l|} 
\\
\end{tabular} & \begin{tabular}{|l}
$2.00 \mathrm{E}-\mathrm{U} 1$ \\
$8.990 \mathrm{0}-01$ \\
\end{tabular} & \begin{tabular}{|l|}
2.9 \\
8.9 \\
\end{tabular} & $\frac{E-01}{E-01}$ & $\frac{2.000 \mathrm{E} \cdot 01}{8.870 \mathrm{E} \cdot 01}$ \\
\hline F Factor & \begin{tabular}{|c|}
$9.680 \mathrm{E}-01$ \\
\end{tabular} & $9.680 E-01$ & \begin{tabular}{|l|}
$9.764 \mathrm{E}-01$ \\
\end{tabular} & 9.764E-01 & $\frac{9.751 \mathrm{E}-01}{5500 \mathrm{E}+04}$ & $\frac{9.157 \mathrm{E}-01}{5000 \mathrm{E}+04}$ & $\frac{0.140 E-01}{5.000 E+04}$ & $\frac{0.140 E-01}{5.000 E+04}$ & $\frac{0.010 E-01}{5000 E+04}$ & \begin{tabular}{|l|}
$.0000 E+04$ \\
$500 E$
\end{tabular} & \begin{tabular}{|c|}
$5.000 \mathrm{E}+04$ \\
\end{tabular} & $\frac{8.338 \mathrm{E}=07}{5000 \mathrm{E}+04}$ & \begin{tabular}{|l}
$8,900 \mathrm{E}=07$ \\
$5,000 \mathrm{E}+04$
\end{tabular} & \begin{tabular}{|l}
$8.9900-01$ \\
$5000 E+04$
\end{tabular} & $\frac{8.870 E-01}{5.000 E+04}$ & $8.870 \mathrm{E}-01$ \\
\hline $\mathrm{Na} / \mathrm{Cs}$ Start & $5.000 E+04$ & $5.000 E+04$ & $5.000 E+04$ & $5.000 \mathrm{E}+04$ & & & & & & & & & & & & $5.000 E+04$ \\
\hline $\mathrm{Na} / \mathrm{Cs}$ Final & $5.834 E+06$ & $6.036 E+06$ & $5.252 E+04$ & $5.256 E+04$ & $2.025 \mathrm{E}+06$ & & $2.098 E+05$ & +05 & $1.408 \mathrm{E}+06$ & 1.36 & 3.0 & $E+05$ & $5.397 \mathrm{E}+06$ & $5.557 E+06$ & $4.706 \mathrm{E}+06$ & $4.676 E+06$ \\
\hline Cs Kd, mL/g & $7.275 E+04$ & $8.026 E+04$ & $1.160 E+01$ & $1.189 E+01$ & $1.228 \mathrm{E}+04$ & $1.240 \mathrm{E}+04$ & $1.185 E+03$ & $1.195 E+03$ & $9.208 \mathrm{E}+03$ & $8.666 E+03$ & $1.403 E+03$ & $1.425 E+03$ & 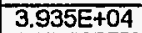 & $4.206 \mathrm{E}+04$ & $2.870 \mathrm{E}+04$ & $2.818 E+04$ \\
\hline Density, g/mL & $7.738 \mathrm{E}-01$ & $7.738 \mathrm{E}-01$ & $5.812 E-01$ & $5.812 \mathrm{E}-01$ & $E-01$ & $=-01$ & $2.434 \mathrm{E}-01$ & E.01 & $3.044 \mathrm{E}-01$ & $3.044 \mathrm{E}-01$ & 7.672E-01 & & 8.999E-01 & & & $1.126 \mathrm{E}+00$ \\
\hline Cs Lambda & $5.629 E+04$ & $6.210 \mathrm{E}+04$ & $6.744 E+00$ & $6.910 E+00$ & $2.748 E+03$ & $2.776 E+03$ & $2.884 E+02$ & $2.909 \mathrm{E}+02$ & $2.803 E+03$ & $2.638 E+03$ & $1.076 \mathrm{E}+03$ & $1.093 \mathrm{E}+03$ & $3.541 E+04$ & $3.785 E+04$ & $3.230 E+04$ & $3.172 E+04$ \\
\hline & & & & & & & & & & & & & & & & \\
\hline mber & AJUC & AJUC-1 & AJVC & AJVC-1 & AJWC & AJWC-1 & JXC & AJXC-1 & $\frac{A J Y C}{R \cdot F \cdot E}$ & AJYC-1 & $\frac{\text { AJZC }}{\text { Zeolite: }}$ & AJZC-1 & $\frac{9}{1 E-91}$ & 10 & 69 & 70 \\
\hline Material. & CST: & IE-910 & AS NaTI: & $8104-170$ & Super & g644 & $\overline{C s}$ & 100 & R.F: E & SC2 & Zeolite: & 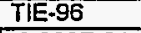 & IE-91 & .08) & IE-911, I & 38B) \\
\hline [Na], Mol. & $2.000 \mathrm{E}-01$ & $2.000 \mathrm{E}-01$ & $2.000 \mathrm{E}-01$ & $2,000 E-01$ & $2.000 \mathrm{E}-01$ & $2.000 E-01$ & $2.000 E-01$ & $2.000 \mathrm{E}-01$ & 2.000E-01 & 2.000E-01 & $\cdot 2.000 \mathrm{E}-01$ & $2.000 E-01$ & $2.000 \mathrm{E}-01$ & $2.000 E-01$ & $2.000 E-01$ & $2.000 \mathrm{E}-01$ \\
\hline F Factor & \begin{tabular}{|c|}
$9.680 \mathrm{E}-01$ \\
\end{tabular} & $9.680 E-01$ & $\begin{array}{l}9.764 \mathrm{E}-01 \\
\end{array}$ & $9.764 \mathrm{E}-01$ & $9.751 \mathrm{E}-01$ & $9.751 E-01$ & $6.148 \mathrm{E}-01$ & $E-01$ & $8.070 \mathrm{E}-01$ & \begin{tabular}{|l|}
$8.070 \mathrm{E}-01$ \\
\end{tabular} & \begin{tabular}{|l|}
$8.338 \mathrm{E}-01$ \\
\end{tabular} & BE-01 & $8.990 \varepsilon-01$ & \begin{tabular}{|l|}
$8.990 \mathrm{E}-01$ \\
\end{tabular} & $8.870 \mathrm{E}-01$ & $8.870 \mathrm{E} \cdot 01$ \\
\hline Na/Cs Start & $5.000 \mathrm{E}+05$ & $5.000 E+05$ & $5.000 E+05$ & $5.000 \mathrm{E}+05$ & $5.000 E+05$ & 5.00 & $5.000 \mathrm{E}+05$ & $\mathrm{JE}+05$ & $5.000 E+05$ & $5.000 E+05$ & $5.000 \mathrm{E}+05$ & \begin{tabular}{|l|}
$5.000 E+05$ \\
\end{tabular} & $5.000 E+05$ & $5.000 E+05$ & $5.000 \mathrm{E}+05$ & $5.000 E+05$ \\
\hline $\mathrm{Na} / \mathrm{Cs}$ Final & $5.250 E+07$ & $5.372 E+07$ & $5.264 E+05$ & $5.252 E+05$ & $2.169 E+07$ & 2.1 & 2.35 & $2.354 \mathrm{E}+06$ & $1.449 \mathrm{E}+07$ & $1.489 \mathrm{E}+07$ & $3.138 E+05$ & $3.145 E+06$ & $4.612 E+07$ & $4.424 \mathrm{E}+07$ & $5.731 \mathrm{E}+07$ & $4.636 \mathrm{E}+07$ \\
\hline Cs Kd, mUg & $7.084 E+04$ & $7.493 E+04$ & \begin{tabular}{|l|}
$1.212 E+01$ \\
\end{tabular} & +01 & $1.271 E+04$ & $1.252 E+04$ & $1,397 \mathrm{E}+03$ & 1.3 & $9.188 E+03$ & $9.538 \mathrm{E}+03$ & $1.434 \mathrm{E}+03$ & $=+03$ & $2.322 E+04$ & IE+04 & 4.3 & $2.814 E+04$ \\
\hline Density, g/mL & \begin{tabular}{|l|}
$7.738 \mathrm{E}-01$ \\
\end{tabular} & $7.738 E-01$ & $5.812 \mathrm{E}-01$ & E-01 & $2.238 E-01$ & $2.238 E-01$ & 2.434E-01 & 2.434E-01 & 3.044E-01 & 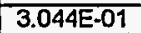 & \begin{tabular}{|c|}
$7.672 E-01$ \\
\end{tabular} & $7.672 E-01$ & $8.999 E-01$ & $8.999 E-01$ & $1.126 \mathrm{E}+00$ & $1.126 E+00$ \\
\hline & $5.482 E+04$ & $5.798 E+04$ & $7.043 E+00$ & $6.794 E+\infty 0$ & $2.844 E+03$ & $2.802 E+03$ & $3.399 \mathrm{E}+02$ & $3.310 E+02$ & $2.797 E+03$ & $2.903 E+03$ & $1.100 \mathrm{E}+03$ & $1.114 E+03$ & $2.090 E+04$ & $1.963 E+04$ & $4.907 \mathrm{E}+04$ & $3.167 E+04$ \\
\hline
\end{tabular}




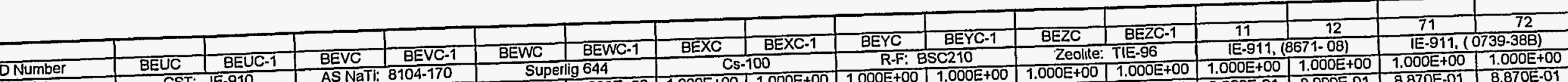

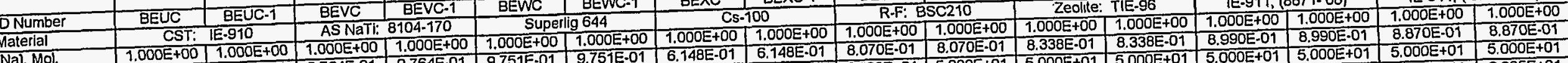

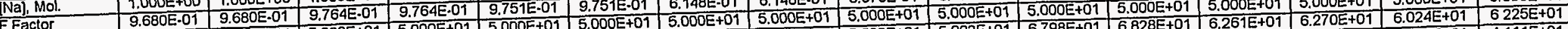

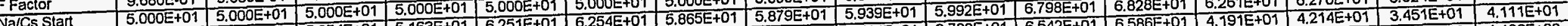

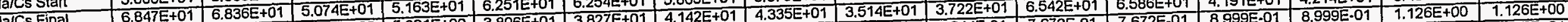

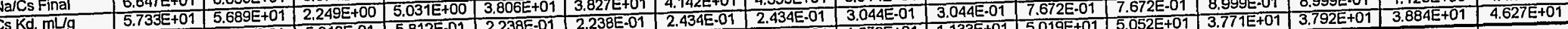

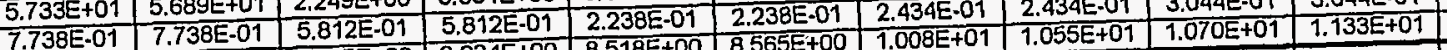

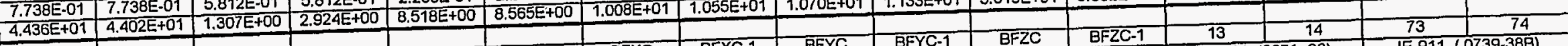

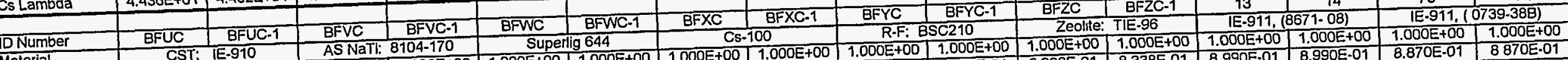

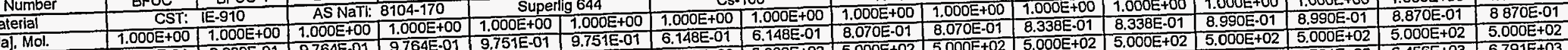

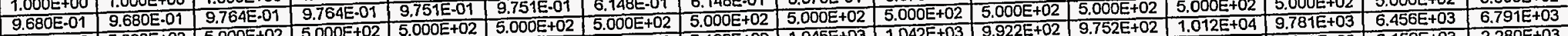

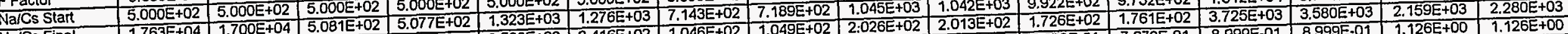

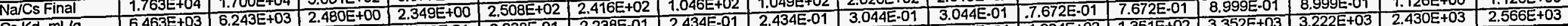
Density, g/mL

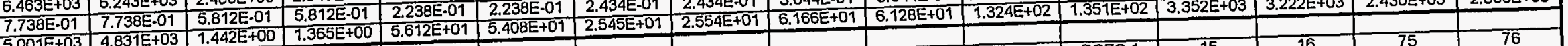
Csambda

Material

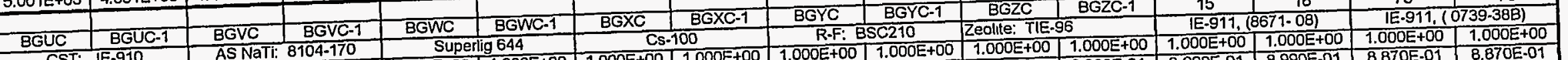

Na), MO

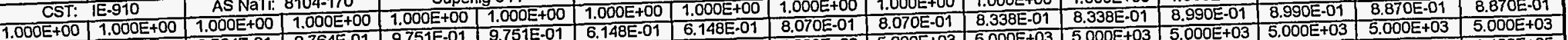

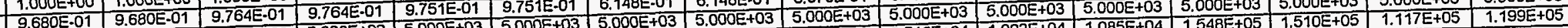

$\mathrm{Kd}, \mathrm{mL}$

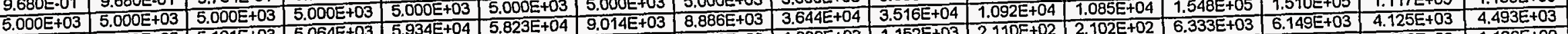

Density, $g / m$

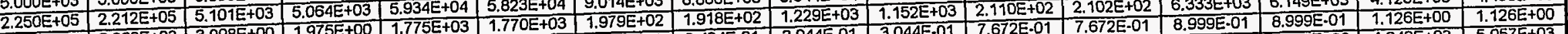
Cs Lambda

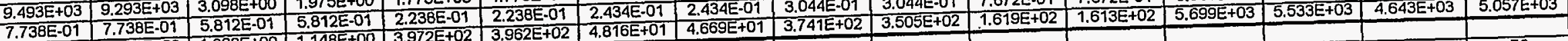

ID Number

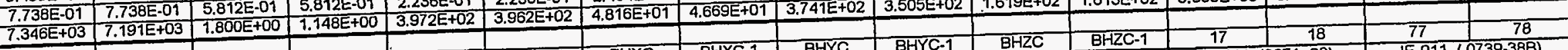
DNumber Na), Mol.

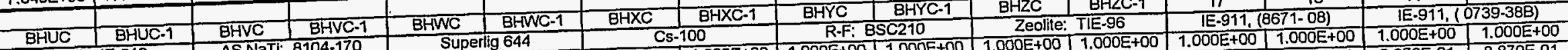
Factor

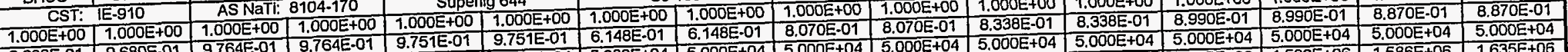

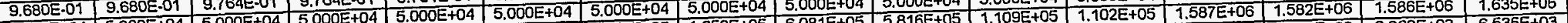
\begin{tabular}{|l|l|l|l|l|l|l|l|l|l|l|l|l|l|l|l|l|l}
$5.000 E+04$ & $5.000 E+04$ & $5.000 E+04$ & $5.000 E+04$ & $5.005 E+05$ & $8.685 E+05$ & $1.058 E+05$ & $1.050 E+05$ & $6.081 E+05$ & $5.816 E+05$ & $1.109 E+05$ & $1.179 E+02$ & $6.082 E+03$ & $6.048 E+03$ & $6.263 E+03$ & $6.535 E+03$ \\
\hline
\end{tabular}

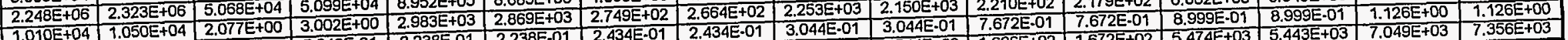

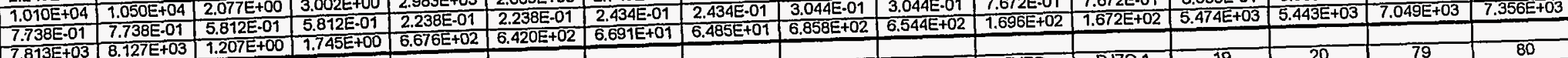

ID Number

Material

FFactor

Na/Cs Start

NarCs Final

Cs Kd, mLg

Censity, g/mL

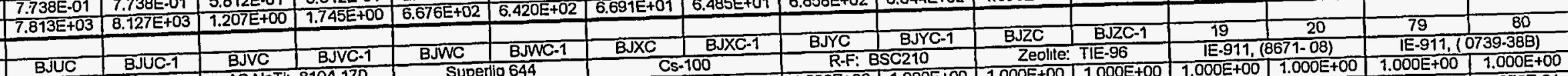

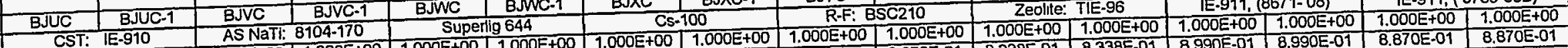

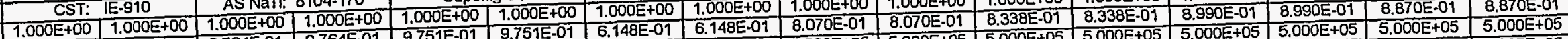

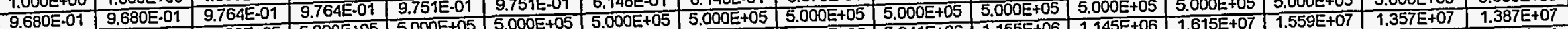

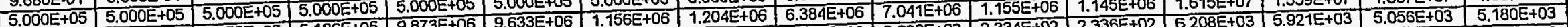

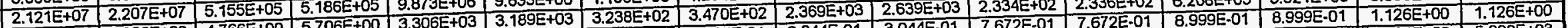
Cs Lambda

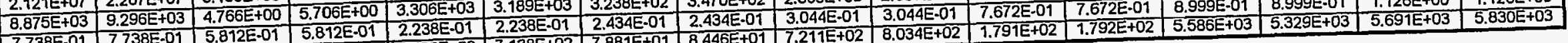
\begin{tabular}{|c|}
\hline $7.738 \mathrm{E}-01$ \\
\hline $6.867 \mathrm{E}+03$ \\
\hline
\end{tabular} 


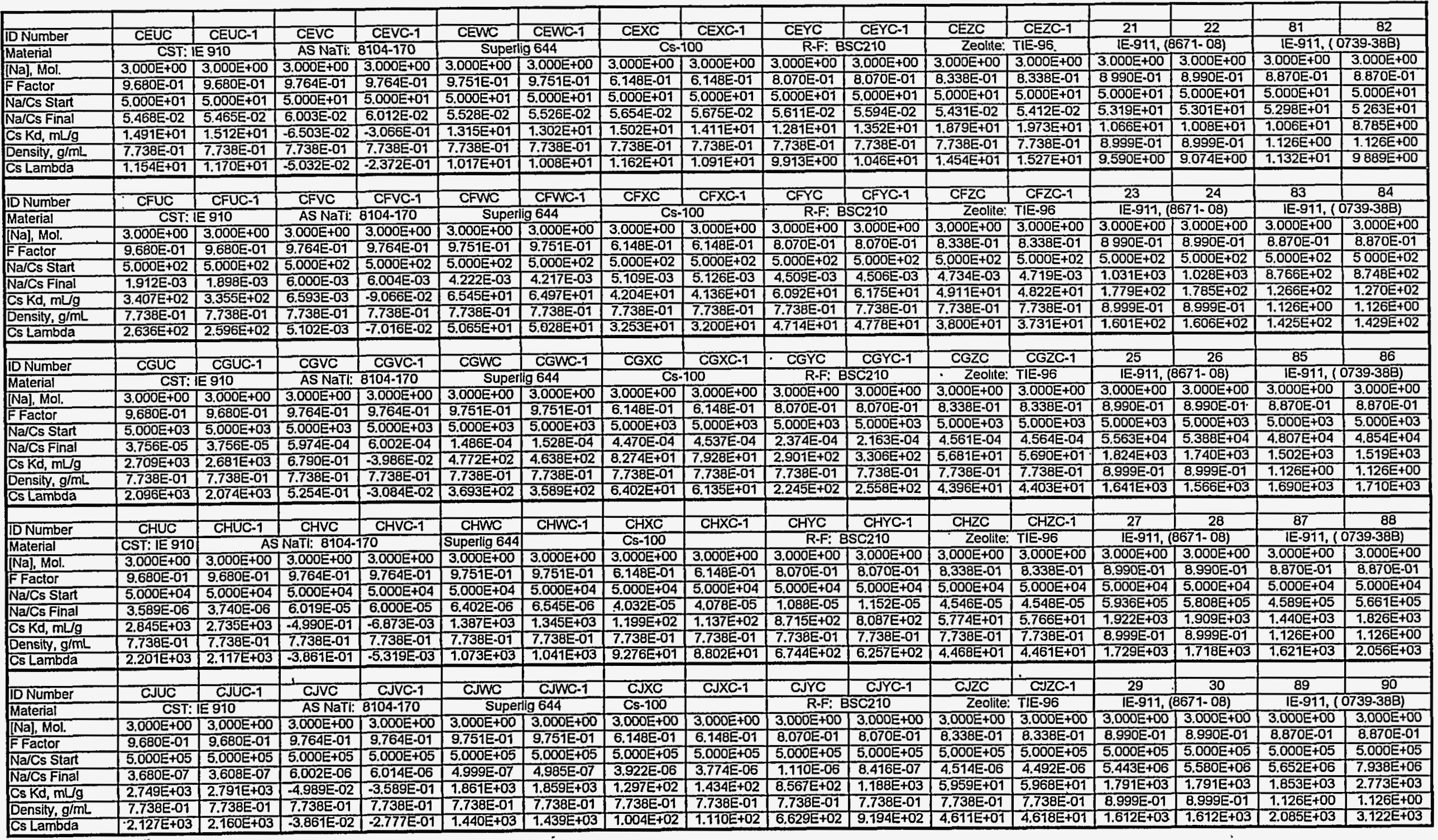




\begin{tabular}{|c|c|c|c|c|c|c|c|c|c|c|c|c|c|c|c|c|}
\hline & & & & & & & & DEXC-1 & & DEY & & DEZC-1 & & 32 & $\overline{D E}$ & $\mathrm{DE2}$ \\
\hline & DEUC & DEUC-1 & DEVC & & DEWC & DEWC-1 & $\frac{D E X C}{C s}$ & & DERC & & Zeolite: & & 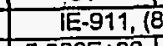 & $\frac{571 \cdot 08)}{5(2085}$ & E-911,1 & \\
\hline Material & & IE-910 & AS NaT: & $8104-170$ & Superl & $\frac{19644}{5.000 E+00}$ & 5.000E+00| & & & & $5.000 E+00$ & $5.000 E+0$ & $5.000 E+00$ & $5.000 E+C$ & $\frac{5.000 E+00}{8800 \cdot 01}$ & $\frac{5.000 E+00}{8.870 E-01}$ \\
\hline 1], MOI & \begin{tabular}{l|l|l}
$00 E+00$ & 5
\end{tabular} & & \begin{tabular}{|l|}
$5.000 E+00$ \\
$9064 \mathrm{~g}-01$
\end{tabular} & \begin{tabular}{|l|l}
$5.000 E+00$ \\
$9.76 E E-01$
\end{tabular} & $\frac{5.000 E+00}{9.751 E-01}$ & $\frac{1.001 \mathrm{E} \cdot 01}{9.751 \mathrm{~T}}$ & \begin{tabular}{|l|}
$6.148 \mathrm{E}-01$ \\
\end{tabular} & $6.148 E \cdot 01$ & $8.070 E-01$ & & $\frac{8.338 E-01}{5000 E+01}$ & $\frac{8.338 E-01}{5500 E+01}$ & \begin{tabular}{l|l|}
$8.990 E-01$ \\
$5000=01$
\end{tabular} & $\frac{8990 \mathrm{E} \cdot 01}{5.000 \mathrm{E}+01}$ & $\frac{8.8 / U E=U 1}{5.000 E+01}$ & $\frac{8.870 E \cdot 01}{5.000 E+01}$ \\
\hline EFand & $\frac{80 E-01}{00 E+01}$ & 9698 & $\mid$\begin{tabular}{|c|}
$9.764 E-01$ \\
$5.000 E+01$
\end{tabular} & \begin{tabular}{|l|l|}
$. .1044-01$ \\
$.000 E+01$
\end{tabular} & $5.000 E+01$ & & $00 E+01$ & $5.000 \mathrm{E}+01$ & & & $\frac{5.000 E+17}{5.315 E+01}$ & $\frac{5.000 E+01}{5.302 E+01}$ & $\frac{5.000 E E+01}{5.195+01}$ & 5.000 & $5.198 E+01$ & $5.181 E+01$ \\
\hline Cs F & $\frac{5.000 E+01}{5.273 E+01}$ & 5.22 & \begin{tabular}{|l|}
$4.992 E+01$ \\
\end{tabular} & \begin{tabular}{|l|l|}
$4.986 E+01$ \\
\end{tabular} & $5.269 E+01$ & & $17 \mathrm{E}+01$ & $217 E+01$ & 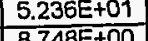 & & $\frac{0.010 E+11}{1.128 E+01}$ & $\frac{0.002 E+01}{1.082 E+01}$ & $6.672 E+00$ & & $738 \mathrm{E}+00$ & $\frac{0.101 E+01}{6.069 E+00}$ \\
\hline & $\frac{5.273 E+01}{8.439 E+00}$ & $\frac{0.22}{7.03}$ & \begin{tabular}{|l|}
$-2.323 E-01$ \\
\end{tabular} & $.4 .435 E-01$ & $8.199 E+00$ & +00 & $2 E+01$ & $054 E+01$ & $\frac{48 E+00}{40 A E-1}$ & & $\frac{1.120 .01}{7.672 E \cdot 01}$ & $7.672 \mathrm{E}-01$ & $8.999 E-01$ & $8.999 \mathrm{E} \cdot 01$ & $.126 \mathrm{E}+00$ & $\frac{1.056 E+00}{1.126}$ \\
\hline & $\begin{array}{l}8.4956+01 \\
7.738 E-01 \\
\end{array}$ & & \begin{tabular}{|c|}
$5.2025 \mathrm{E}-01$ \\
$5.812 \mathrm{E} \cdot 01$ \\
\end{tabular} & \begin{tabular}{|l|l|}
$5.812 E .01$ \\
\end{tabular} & $2.238 E-01$ & & $\frac{2.434 E-01}{2560+00}$ & $\frac{2.4344-01}{2.56 E+00}$ & \begin{tabular}{|l|l|}
$3.044 E-01$ \\
$2.663 E+00$
\end{tabular} & $2.462 E+00$ & $\frac{1.01250}{8.650 E+00}$ & $8.304 E+00$ & $6.004 E+00$ & $6.674 E+00$ & $E+\infty$ & $\frac{1.120+100}{6.832 E+00}$ \\
\hline S Le & $6.530 E+00$ & $5.440 E+00$ & \begin{tabular}{|c|}
-1.3 \\
\end{tabular} & $-2.578 E .01$ & $1.835 \mathrm{E}+00$ & $1.805 E+00$ & & & & & & & & & & \\
\hline mber & & & & & $\overline{F W}$ & DFWC-1 & $\overline{D F X C}$ & $\overline{C C}-1$ & DFYC & DFYC-1 & DFZC & DFZC-1 & - & 34 & $\frac{D F 1}{T F-91}$ & $\frac{D F 2}{39.38}$ \\
\hline moer & DFUC & & $\overline{A S}$ & 810 & Super & 9644 & & & & C210 & Zeolite: & TE-96 & $\frac{\mid \mathrm{E}-911, \text {, }}{0.00 \mathrm{E}}$ & (1-08) & E- $\begin{array}{l}\text { E- } 911,1,(6 \\
000+00\end{array}$ & $\frac{39.38 B)}{5.000 E+00}$ \\
\hline a] Mol. & $\frac{C 51}{000 E+00}$ & $\frac{E-910}{5.000 E+00}$ & & 5.0 & $5.000 \mathrm{E}+00$ & $5.000 E+00$ & $5.000 E+00$ & & $5.000 E+00$ & & $\frac{5.000 E E+00}{8.338 E-01}$ & $\frac{5.000 E+00}{8.338 E-01}$ & $\frac{5.000 E+00}{8.990 E-01}$ & 8.0900 & 870E.01 & $\frac{5.000 E+00}{8.870 E-01}$ \\
\hline & $680 \mathrm{E}-01$ & $9.680 E-01$ & & 9.7 & \begin{tabular}{|l|}
$9.751 E-01$ \\
\end{tabular} & $=01$ & \begin{tabular}{|c|}
$6.148 E-01$ \\
\end{tabular} & $\frac{6.148 \mathrm{E}-01}{6.01}$ & $\begin{array}{l}8.070 E-01 \\
50005+02\end{array}$ & & DEE+02 & & $5.000 E+02$ & $5.000 E+02$ & & D.UEE+01 \\
\hline & DOOE +02 & $5.000 E+02$ & & & & & $5.000 E+02$ & $\frac{5.000 E+02}{5562 E+02}$ & $\frac{5.000 E+02}{6098 E+22}$ & & & 67 & $7.375 E+02$ & $7.346 \mathrm{E}$ & & $5+02$ \\
\hline & & & & & & & 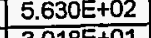 & $\frac{5.624 E+02}{3.025}$ & $\frac{6.098 E+02}{1056 C+11}$ & & & $\frac{2.493 E}{2.4936}$ & $7.763 E+01$ & $7.598 \mathrm{E}$ & & $E+01$ \\
\hline & $\overline{002}$ & 1.06 & & & $i+01$ & & & $3.042 E+01$ & $\frac{4.066 E+01}{3044 E-01}$ & & $7.672 E=01$ & & $8.999 \mathrm{E}-01$ & $8.999 \mathrm{E}$ & & \\
\hline & 7.73 & -011 & & & & & $\begin{array}{l}2,434 E-01 \\
7.345 E+00\end{array}$ & \begin{tabular}{|l}
$2.434 E-01$ \\
$7.403+00$
\end{tabular} & $\frac{3.344 E-01}{1.238 E+01}$ & $1.236 \mathrm{E}+01$ & $1.863 \mathrm{E}+01$ & $1.913 E+01$ & $6.986 E+01$ & $6.838 \mathrm{E}+01$ & $6.620 E+01$ & $=+01$ \\
\hline s Lambda & $8.013 E+01$ & $8.220 E+01$ & $-1.677 E-01$ & 3. & $9.307 E+00$ & $9.553 E+00$ & & & & & & & & & & \\
\hline & & & & & DGWC & $\overline{V C-1}$ & $\overline{D G X C}$ & $\mathrm{XXC-1}$ & $Y \overline{Y C}$ & DGYC-1 & DGZC & $c=1$ & & $(1.08)$ & $\frac{D G 1}{E-91}$ & $\frac{\mathrm{DG} 2}{39.38 \mathrm{~B})}$ \\
\hline & $\overline{D G 1}$ & & & & , t & 644 & & & R-F:E & & Zeolite & TIE-96 & $\frac{\mid E-911,(1}{0.005+00}$ & 7.1.-08) & $\frac{1 E-9}{5000+1}$ & $\frac{39 \cdot 38 B)}{5.000+00}$ \\
\hline & & & $\frac{\text { AS NaTi: }}{5000+00}$ & 5.00 & $5.000 E+00$ & +00 & & 5.6 & $5.000 E+00$ & & $5.000 E+00$ & $\begin{array}{l}5.0003 E+ \\
8333 E-\end{array}$ & & $\frac{5.000}{8.990}$ & & $\frac{5.000+00}{8.870 E-01}$ \\
\hline & 01 & 5. & $\frac{0.000 L-701}{9.764 E-01}$ & 01 & $9.751 \mathrm{E}-01$ & $E-01$ & & $\overline{E-01} \quad-\quad$ & & EE-01 & $\frac{8.338 E-01}{5000 E+03}$ & $\frac{8.336 E-01}{5.000 E+03}$ & 5.0 & & & $\begin{array}{l}\frac{8}{5.0100 E}+03 \\
5.000+03 \\
\end{array}$ \\
\hline & .01 & & $5.000 E+03$ & & & & & & & $E+03$ & $5763 E+1$ & $.764 E+03$ & $3.102 \mathrm{E}$ & 3.1 & & $49 E+04$ \\
\hline & $\frac{5.000 E+03}{4590 F+4}$ & $\frac{3.6}{44}$ & $4.983 E+03$ & & & & & & & 02 & $2.701 E+01$ & $2.763 E+01$ & $8.673 E+02$ & & & $\frac{7 E+02}{4 E}$ \\
\hline & $\frac{4.590 E+04}{1.735+03}$ & & -5.11 & & & & & & & $\frac{1.775 E+02}{3.044 E-01}$ & $7.672 E$ & 7.6 & $8 . \overline{99}$ & & & \\
\hline & $\frac{1.373 E+03}{7738 E-01}$ & $\frac{1.5}{77}$ & $\frac{-3.1}{5.81}$ & & & & $2.434 \mathrm{E}-01$ & & & & $\frac{1.014}{2.072}$ & $E+01$ & $805 E+02$ & $7.947 \mathrm{E}+02$ & & +02 \\
\hline & \begin{tabular}{|c|}
$7.738 E-01$ \\
$1.062 E+03$
\end{tabular} & $\frac{7.138 \mathrm{E}}{1.010 \mathrm{E}-\mathrm{T}}$ & $-2.973 \mathrm{E}-01$ & $4 \mathrm{E}-02$ & $E+01$ & $6.065 E+01$ & $1.506 E+01$ & & & & & & & & & \\
\hline Cs Lam & & & & & & & & & & & & $\overline{c-1}$ & 37 & & & \\
\hline ber & DHUC & $J C-1$ & & $=1$ & HWC & DHWC-1 & & XC-1 & & & zeolite & TIE-96 & TE-911 & $671-1$ & & \\
\hline & & & & $\frac{1}{81}$ & & ig 6 & & & $n_{1}$ & $=+00$ & $5000+00$ & $55.000 E+00$ & $.000 E+00$ & \begin{tabular}{l|l}
0 & $5.000 E+00$
\end{tabular} & & 008 \\
\hline & & , & & 5.00 & 00 & $E+00$ & & & & & $\frac{6338 \mathrm{E}}{8.33}$ & & 8. & $8.990 \mathrm{E}-01$ & & \\
\hline & & & & 9.76 & & & 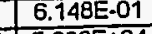 & & & & 5000 & 5.00 & & & & \\
\hline & & & & \begin{tabular}{l|l}
45 \\
\end{tabular} & & & $00 E+04$ & $\begin{array}{l}4 \\
\end{array}$ & & & $5818 E+04$ & \begin{tabular}{l|l}
54 & 5.76 \\
\end{tabular} & \begin{tabular}{l|l}
4 & 3.5 \\
\end{tabular} & & & \\
\hline & & & & \begin{tabular}{|l|l|}
4 & $4.977 E+04$
\end{tabular} & $3.444 E+05$ & & $E+04$ & & & & $2048+01$ & \begin{tabular}{|l|l}
31 & 273 \\
01
\end{tabular} & & & & \\
\hline & & & & \begin{tabular}{|l|l}
3 & 7.037 \\
\end{tabular} & & & & & & & & & & & & +00 \\
\hline & 1.572 & & & \begin{tabular}{l|l|l|l|}
5 & 5.81 \\
\end{tabular} & & & & & & & & & & & & $\frac{1.120 \mathrm{C}}{1.127 E+03}$ \\
\hline & & & $\begin{array}{l}\frac{5.812 E-01}{-5.669 E-03} \\
\end{array}$ & \begin{tabular}{l|l} 
\\
3 & -4.05 \\
\end{tabular} & $2.105 E+02$ & & 01 & & & & & & & & & \\
\hline \begin{tabular}{|l} 
Cs Lambda \\
\end{tabular} & & & & & & & & & & & $5 J z$ & & 35 & & & \\
\hline & & UC-1 & & & DJWC & DSWC-1 & $\overline{D J X}$ & & & (C-1 & voc & TTE: & & & & \\
\hline DD Number & & UL-1 & & & sol & . & & & $\overline{5000}$ & & 2 & & & & & \\
\hline & & $\begin{array}{ll}-9-910 \\
50002\end{array}$ & & $0 \longdiv { 5 . c }$ & $5.000 \mathrm{E}$ & $++\infty$ & & 0 & & & & & & & & \\
\hline & & $\frac{5.006}{9.68}$ & & & 9. & 01 & & SE & & $\frac{10-11}{F+05}$ & & & \begin{tabular}{l|l}
55 & 5.00
\end{tabular} & 5.000 & & \\
\hline & & $\frac{01}{+05}$ & & & & & 95 & & & & & 5.8 & 05 & & & \\
\hline & 5.00 & $\frac{0+05}{0+20}$ & & \begin{tabular}{|l|l|}
5 & 5.00 \\
\end{tabular} & & & \begin{tabular}{c|c}
5.7 .35 \\
\end{tabular} & & & & & & th & olution. & & \\
\hline & $5.0 / 6 t+U 0$ & $\frac{0.1201}{156 F+03}$ & & & & & $\frac{32}{2}$ & & & & & & & & & \\
\hline $\mathrm{m}$ & $545 E$ & & & & & & & & & & & & & & & \\
\hline
\end{tabular}




\begin{tabular}{|c|c|c|c|c|c|c|c|c|c|c|c|c|c|c|c|c|}
\hline & & & & & & & & & & & & & & & & \\
\hline ID Number & 41 & 42 & & 44 & & 46 & 47 & 48 & 49 & 50 & & & & & & \\
\hline Material & TE-911, & 571-08) & EE-911., & $8679-08)$ & E-911, & $8671-08)$ & IE-911, ( & $8671-08)$ & $\mid \mathbb{E}-911,($ & $8671-08)$ & & & & & & \\
\hline [Na], Mol. & $7.000 E+00$ & $7.000 E+00$ & $7.000 \mathrm{E}+00$ & $7.000 \varepsilon+00$ & $7.000 E+00$ & $7.000 E+00$ & $7.000 E+00$ & $7.000 E+00$ & $7.000 E+00$ & $7.000 \mathrm{E}+00$ & & & & & & \\
\hline F Factor & $8.990 E-01$ & $8.990 E-01$ & $8.990 \mathrm{E}-01$ & $8.990 \mathrm{E} \cdot 01$ & $8.990 E-01$ & $8.990 \mathrm{E}-01$ & $8.990 \mathrm{E}-01$ & 8.990 E-01 & $8.990 E-01$ & $8.990 \mathrm{E}-01$ & & & & & & \\
\hline Na/Cs Start & $5.000 E+01$ & $\overline{5.000 E+01}$ & $5.000 E+02$ & $5.000 E+02$ & $5.000 E+03$ & $5.000 E+03$ & $5.000 E+04$ & $5.000 E+04$ & $5.000 E+05$ & $5.000 \mathrm{E}+05$ & & & & & & \\
\hline Na/CS Final & $5.118 E+01$ & $\overline{5.089 E+01}$ & $6.347 E+02$ & $6.299 E+02$ & $2.120 E+04$ & $2.070 E+04$ & $2.789 E+05$ & $2.741 E+05$ & $2.645 E+06$ & $2.708 E+06$ & & & & & & \\
\hline$\overline{C s ~ K d, ~ m L g}$ & $3.908 E+00$ & $2.952 E+00$ & $4.494 E+01$ & $4.323 E+01$ & $5.532 E+02$ & $5.354 E+02$ & $7.918 E+02$ & $7.728 E+02$ & $E+02$ & $\overline{21 E+02}$ & & & & & & \\
\hline Density, $\mathrm{g} / \mathrm{mL}$ & $8.999 \mathrm{E}-01$ & \begin{tabular}{|l|}
$8.999 E-01$ \\
\end{tabular} & $8.999 \mathrm{E}-01$ & $8.999 \mathrm{E}-01$ & $8.999 \mathrm{E} \cdot 01$ & $8.999 \mathrm{E} \cdot 01$ & $8.999 \mathrm{E} \cdot 01$ & $8.999 E-01$ & $8.999 E-01$ & $8.999 \mathrm{E}-01$ & & & & & & \\
\hline Cs Lambda & $3.517 \mathrm{E}+00$ & $2.656 E+00$ & $4.044 E+01$ & $3.891 E+01$ & $4.978 E+02$ & $4.818 \mathrm{E}+02$ & $7.125 \mathrm{E}+02$ & $6.955 E+02$ & $6.557 \mathrm{E}+02$ & $6.768 \mathrm{E}+02$ & & & & & & \\
\hline & & & & & & & & & & & & & & & & \\
\hline ID Number & EE1 & EE2 2 & EF1 & EF2 & FG1 & EG? & $\mathrm{FH} 1$ & $\mathrm{FH}$ & EJ1 & FI? & & & & & & \\
\hline Material & & & & & DP: IE-911, b & atch \#0739.3 & & & & & & & & & & \\
\hline [Na], Mol. & $7.000 E+00$ & $7.000 E+00$ & $7.000 E+00$ & $7.000 E+00$ & $7.000 E+00$ & $7.000 \mathrm{E}+00$ & $7.000 \mathrm{E}+00$ & $7.000 E+00$ & $7.000 E+00$ & $7.000 \mathrm{E}+00$ & & & & & & \\
\hline F Factor & $8.870 \mathrm{E} \cdot 01$ & $8.870 \mathrm{E}-01$ & $8.870 \mathrm{E}-01$ & 8.870E-01 & 8.870E-01 & 8.870E-01 & $8.870 \mathrm{E}-01$ & $8.870 \mathrm{E} \cdot 01$ & $8.870 E-01$ & $8.870 \mathrm{E}-01$ & & & & & & \\
\hline Na/Cs Start & $5.000 E+01$ & $5.000 E+01$ & $5.000 E+02$ & $5.000 \mathrm{E}+02$ & $5.000 \mathrm{E}+03$ & $5.000 \mathrm{E}+03$ & $5.000 \mathrm{E}+04$ & $5.000 E+04$ & $5.000 E+05$ & $5.000 \mathrm{E}+05$ & & & & & & \\
\hline Na/Cs Final & $5.101 E+01$ & $5.100 E+01$ & $6.149 E+02$ & $6.155 E+02$ & $1.754 E+04$ & $1.786 E+04$ & $2.564 E+05$ & $2.596 E+05$ & $2.682 E+06$ & $2.679 E+06$ & & & & & & \\
\hline Cs Kd, mLg & $3.397 \mathrm{E}+00$ & $3.388 \mathrm{~B}+00$ & $3.916 E+01$ & 3.911E+01 & $4.348 E+02$ & $4.422 E+02$ & $7.194 \mathrm{E}+02$ & $7.242 \mathrm{E}+02$ & $7.588 E+02$ & $7.646 E+02$ & & & & & & \\
\hline Density, $\mathrm{g} / \mathrm{mL}$ & $1.126 E+00$ & $1.126 E+00$ & $1.126 E+00$ & $1.126 \mathrm{E}+00$ & $1.126 \mathrm{E}+00$ & $1.126 E+00$ & $1.126 E+00$ & $1.126 \mathrm{E}+00$ & $1.126 E+00$ & $1.126 \mathrm{E}+00$ & & & & & & \\
\hline Cs Lambda & $3.824 E+00$ & $3.814 E+00$ & $4.407 E+01$ & $4.402 E+01$ & $4.894 \mathrm{E}+02$ & $4.978 \mathrm{E}+02$ & $8.098 E+02$ & $8.151 E+02$ & $8.541 \mathrm{E}+02$ & $8.606 E+02$ & & & & & & \\
\hline & & & & & & & & & & & & & & & & \\
\hline & & & & & & & & & & & & & & & & \\
\hline Waste-DSSF & nogin 70 & $\frac{1}{10100000}$ & 100 & Tam & 356 & & montium & क्या & $1 c=50000$ & & & & & & & \\
\hline ID Number & DJUS & DJUS-1 & DJVS & DJVS-1 & DJWS & DJWS-1 & DJXS & DJXS-1 & DJYS & DIYS-1 & 0175 & 17 & & & & \\
\hline Material & CST: & $\frac{1}{\mathbb{I} E-910}$ & AS NaTt: & 8104-170 & $\frac{\text { Super }}{\text { Sup }}$ & $\frac{0504}{9644}$ & $\frac{\mathrm{D}_{\mathrm{NAS}} \mathrm{Cs} .}{\text {. }}$ & $\frac{0}{00}$ & R-F: E & $\frac{1}{150210}$ & $\frac{D J L S}{\text { Zeolite }}$ & :TIE=96-1 & & & & \\
\hline [Na], Mol. & $5.000 E+00$ & $5.000 E+00$ & $5.000 E+00$ & $5.000 E+00$ & $5.000 E+00$ & $E+00$ & $5.000 E+00$ & $5.000 E+00$ & $5.000 E+00$ & $5.000 E+00$ & $5.000 E+00$ & $5.000 E+00$ & & & & \\
\hline F Factor & $9.680 \mathrm{E}-01$ & $9.680 E-01$ & $9.764 E-01$ & 9.764E.01 & 9.751E-01 & $9.751 E-01$ & $6.148 E-01$ & $6.148 E-01$ & $8.070 \mathrm{E}-01$ & \begin{tabular}{|l|}
$070 \mathrm{E}-01$ \\
\end{tabular} & 8.338E-01 & \begin{tabular}{|c|}
$8.338 \mathrm{E} \cdot 01$ \\
\end{tabular} & & & & \\
\hline Na/Sr Start & $7.000 E+07$ & $7.000 E+07$ & $7.000 E+07$ & $7.000 E+07$ & $7.000 E+07$ & $7.000 E+07$ & $7.000 E+07$ & $7.000 E+07$ & $7.000 E+07$ & $7.000 \mathrm{E}+07$ & $7.000 E+07$ & $7.000 \mathrm{E}+07$ & & & & \\
\hline Na/Sr Final & $2.682 E+12$ & $2.682 E+12$ & $2.682 E+12$ & $2.682 E+12$ & $1.079 E+08$ & $1.089 E+08$ & $9.147 E+07$ & $8.998 E+07$ & $1.020 E+08$ & $1.177 E+08$ & $1.756 E+09$ & $1.629 \mathrm{E}+09$ & & & & \\
\hline $\mathrm{SrKd}, \mathrm{mLg}$ & $5.930 E+C$ & $5.925 E+06$ & $5.791 E+06$ & $5.881 E+06$ & $8.151 E+01$ & $8.462 E+01$ & $7.368 E+01$ & $6.819 E+01$ & $8.418 E+01$ & $1.255 E+02$ & $3.993 E+03$ & $4.268 \mathrm{E}+03$ & & & & \\
\hline Density & $7.7388-01$ & $7.738 \mathrm{E}-01$ & $5.812 E-01$ & $5.812 E-01$ & $2.238 E-01$ & $2.238 E-01$ & $2.434 \mathrm{E}-01$ & $2.434 \mathrm{E}-01$ & 3.044E-01 & $3.044 \mathrm{E}-01$ & $7.672 \mathrm{E}-01$ & $7.672 \mathrm{E} \cdot 01$ & & & & \\
\hline Sr Lambda & $4.588 E+06$ & $4.585 E+06$ & $3.366 E+06$ & $3.418 \mathrm{E}+06$ & $1.824 E+01$ & $1.894 E+01$ & $1.793 E+01$ & $1.660 \mathrm{E}+01$ & $2.562 E+01$ & $3.819 \mathrm{E}+01$ & $3.063 E+03$ & $3.274 E+03$ & & & & \\
\hline
\end{tabular}





\section{Appendix C}

Cesium and Strontium $\dot{\lambda}$ Values for the

Actual Waste Experiments 


\begin{tabular}{|c|c|c|c|c|c|c|c|c|}
\hline & \multicolumn{5}{|c|}{ Phase / Experiment: Phase Ratio $=150 \mathrm{~mL} / \mathrm{g}$, Cs lambdas } & & & \\
\hline ID Number & CS1D & CS1Q & CS2D & $\overline{C S 2 Q}$ & CS3D & $\operatorname{cs} 3 Q$ & CS4D & $\operatorname{CS} 4 Q$ \\
\hline Material & CS-100 & CS-100 & CS-100 & CS-100 & CS-100 & CS-100 & $C S-100$ & CS-100 \\
\hline [Na], Mol. & 5.01 & 5.01 & 5.01 & 5.01 & 5.01 & 5.01 & 5.01 & 5.01 \\
\hline F Factor & 0.6671 & 0.6671 & 0.6671 & 0.6671 & 0.6671 & 0.6671 & 0.6671 & 0.6671 \\
\hline $\mathrm{Na} / \mathrm{Cs}$ Start & $1.05 E+02$ & $1.05 E+02$ & $1.05 \mathrm{E}+03$ & $1.05 E+03$ & $1.14 \mathrm{E}+04$ & $1.14 E+04$ & $7.84 \mathrm{E}+04$ & $7.84 E+04$ \\
\hline Na/Cs Final & $1.15 \mathrm{E}+02$ & $1.13 \mathrm{E}+02$ & $1.24 \mathrm{E}+03$ & $1.23 E+03$ & $1.48 \mathrm{E}+04$ & $1.51 E+04$ & $1.13 E+05$ & $1.09 \mathrm{E}+05$ \\
\hline Cs Kd Value & $2.04 \mathrm{E}+01$ & $1.54 \mathrm{E}+01$ & $3.92 E+01$ & $3.62 E+01$ & $6.68 \mathrm{E}+01$ & $7.17 E+01$ & $9.52 \mathrm{E}+01$ & $8.51 E+01$ \\
\hline Density & 0.2434 & 0.2434 & 0.2434 & 0.2434 & 0.2434 & 0.2434 & 0.2434 & 0.2434 \\
\hline Cs Lambda & $4.96 \mathrm{E}+00$ & $3.75 \mathrm{E}+00$ & $9.54 \mathrm{E}+00$ & $8.82 E+00$ & $1.63 E+01$ & $1.74 E+01$ & $2.32 E+01$ & $2.07 E+01$ \\
\hline ID Number & RF1D & RF1Q & RF2D & RF2Q & RF3D & RF3Q & RF4D & RF4Q \\
\hline Material & $R-F(210)$ & $R-F(210)$ & R-F (210) & $R-F(210)$ & R-F (210) & R-F (210) & R-F (210) & R-F (210) \\
\hline [Na], Mol. & 5.01 & 5.01 & 5.01 & 5.01 & 5.01 & 5.01 & 5.01 & 5.01 \\
\hline F Factor & 0.8109 & 0.8109 & 0.8109 & 0.8109 & 0.8109 & 0.8109 & 0.8109 & 0.8109 \\
\hline Na/Cs Start & $1.05 E+02$ & $1.05 E+02$ & $1.05 E+03$ & $1.05 \mathrm{E}+03$ & $1.14 E+04$ & $1.14 E+04$ & $7.84 E+04$ & $7.84 E+04$ \\
\hline $\mathrm{Na} / \mathrm{Cs}$ Final & $1.13 \mathrm{E}+02$ & $1.10 E+02$ & $1.27 \mathrm{E}+03$ & $1.27 E+03$ & $1.99 E+04$ & $2.00 E+04$ & $1.96 E+05$ & $1.99 \mathrm{E}+05$ \\
\hline Cs Kd Value & $1.35 \mathrm{E}+01$ & $7.56 \mathrm{E}+00$ & $3.82 \mathrm{E}+01$ & $3.69 E+01$ & $1.32 E+02$ & $1.33 E+02$ & $2.60 \mathrm{E}+02$ & $2.68 E+02$ \\
\hline Density & 0.3044 & 0.3044 & 0.3044 & 0.3044 & 0.3044 & 0.3044 & 0.3044 & 0.3044 \\
\hline Cs Lambda & $4.11 E+00$ & $2.30 E+00$ & $1.16 E+01$ & $1.12 \mathrm{E}+01$ & $4.02 E+01$ & $4.04 E+01$ & $7.90 E+01$ & $8.15 E+01$ \\
\hline ID Number & SL1D & SL1Q & SL2D & SL2Q & SL3D & SL3Q & $\overline{\text { SL4D }}$ & SL4Q \\
\hline Material & SL-644 & SL-644 & SL-644 & SL-644 & SL-644 & SL-644 & SL-644 & SL-644 \\
\hline [Na], Mol. & 5.01 & 5.01 & 5.01 & 5.01 & 5.01 & 5.01 & 5.01 & 5.01 \\
\hline F Factor & 0.9436 & 0.9436 & 0.9436 & 0.9436 & 0.9436 & 0.9436 & 0.9436 & 0.9436 \\
\hline $\mathrm{Na} / \mathrm{Cs}$ Start & $1.05 \mathrm{E}+02$ & $1.05 E+02$ & $1.05 E+03$ & $1.05 E+03$ & $1.14 \mathrm{E}+04$ & $1.14 \mathrm{E}+04$ & $7.84 E+04$ & $7.84 E+04$ \\
\hline $\mathrm{Na} / \mathrm{Cs}$ Final & $1.17 E+02$ & $1.13 \mathrm{E}+02$ & $1.49 E+03$ & $1.49 E+03$ & $3.76 E+04$ & $3.78 \mathrm{E}+04$ & $4.92 E+05$ & $4.96 E+05$ \\
\hline Cs Kd Value & $1.73 \mathrm{E}+01$ & $1.19 \mathrm{E}+01$ & $6.56 E+01$ & $6.56 E+01$ & $3.58 \mathrm{E}+02$ & $3.60 E+02$ & $8.05 E+02$ & $8.11 E+02$ \\
\hline Density & 0.2238 & 0.2238 & 0.2238 & 0.2238 & 0.2238 & 0.2238 & 0.2238 & 0.2238 \\
\hline Cs Lambda & $3.88 E+00$ & $2.66 \mathrm{E}+00$ & $1.47 \mathrm{E}+01$ & 1.47E+01 & $8.01 E+01$ & $8.05 E+01$ & $1.80 \mathrm{E}+02$ & $1.82 E+02$ \\
\hline ID Number & CP1D & $\overline{\text { CP1Q }}$ & CP2D & CP2Q & CP3D & CP3Q & CP4D & CP4Q \\
\hline Material & IE-910 & IE-910 & IE-910 & IE-910 & IE-910 & IE-910 & IE-910 & IE-910 \\
\hline [Na], Mol. & 5.01 & 5.01 & 5.01 & 5.01 & 5.01 & 5.01 & 5.01 & 5.01 \\
\hline F Factor & 0.9841 & 0.9841 & 0.9841 & 0.9841 & 0.9841 & 0.9841 & 0.9841 & 0.9841 \\
\hline $\mathrm{Na} / \mathrm{Cs}$ Start & $1.05 E+02$ & $1.05 E+02$ & $1.05 E+03$ & $1.05 E+03$ & $1.14 E+04$ & $1.14 E+04$ & $7.84 E+04$ & $7.84 E+04$ \\
\hline Na/Cs Final & $1.18 E+02$ & $1.15 E+02$ & $2.98 \mathrm{E}+03$ & $2.93 E+03$ & $9.05 E+04$ & $8.76 E+04$ & $4.91 E+05$ & $7.36 E+05$ \\
\hline Cs Kd Value & $1.89 E+01$ & $1.45 E+01$ & $2.76 E+02$ & $2.69 E+02$ & $9.96 \mathrm{E}+02$ & $9.59 E+02$ & $7.72 E+02$ & $1.23 \mathrm{E}+03$ \\
\hline Density & 0.7738 & 0.7738 & 0.7738 & 0.7738 & 0.7738 & 0.7738 & 0.7738 & 0.7738 \\
\hline Cs Lambda & $1.47 E+01$ & $1.12 \mathrm{E}+01$ & $2.14 E+02$ & $2.08 E+02$ & $7.71 E+02$ & $7.42 E+02$ & $5.98 E+02$ & $9.54 \mathrm{E}+02$ \\
\hline ID Number & CE1D & CE1Q & CE2D & CE2Q & CE3D & CE3Q & CE4D & CE4Q \\
\hline Material & IE-911, ( & 739-38B) & IE-911, ( & $73938 B)$ & IE-911, ( & $739-38 B$ & IE-911, I & 739-38B) \\
\hline [Na], Mol. & 5.01 & 5.01 & 5.01 & 5.01 & 5.01 & 5.01 & 5.01 & 5.01 \\
\hline F Factor & 0.8695 & 0.8695 & 0.8695 & 0.8695 & 0.8695 & 0.8695 & 0.8695 & 0.8695 \\
\hline $\mathrm{Na} / \mathrm{Cs}$ Start & $1.05 \mathrm{E}+02$ & $1.05 \mathrm{E}+02$ & $1.05 E+03$ & $1.05 E+03$ & $1.14 E+04$ & $1.14 \mathrm{E}+04$ & $7.84 E+04$ & $7.84 E+04$ \\
\hline Na/Cs Final & $1.13 \mathrm{E}+02$ & $1.11 \mathrm{E}+02$ & $1.99 \mathrm{E}+03$ & $1.88 E+03$ & $5.44 E+04$ & $5.51 E+04$ & $4.41 E+05$ & $4.49 E+05$ \\
\hline Cs Kd Value & $1.26 \mathrm{E}+01$ & $9.82 E+00$ & $1.46 \mathrm{E}+02$ & $1.29 E+02$ & $6.46 \mathrm{E}+02$ & $6.56 E+02$ & $7.82 E+02$ & $7.97 E+02$ \\
\hline Density & 1.1256 & 1.1256 & 1.1256 & 1.1256 & 1.1256 & 1.1256 & 1.1256 & 1.1256 \\
\hline Cs Lambda & $1.41 E+01$ & $1.11 \mathrm{E}+01$ & $1.64 E+02$ & $1.46 \mathrm{E}+02$ & $7.27 \mathrm{E}+02$ & $7.38 \mathrm{E}+02$ & $8.80 \mathrm{E}+02$ & $8.97 E+02$ \\
\hline
\end{tabular}




\begin{tabular}{|c|c|c|c|c|c|c|c|c|}
\hline ID Number & TI4D & TI4Q & & & & & & \\
\hline Material & AS NaTi & AS NaTi & & & & & & \\
\hline [Na], Mol. & 5.01 & 5.01 & & & & & & \\
\hline F Factor & 1.0051 & 1.0051 & & & & & & \\
\hline $\mathrm{Na} / \mathrm{Cs}$ Start & $7.84 E+04$ & $7.84 E+04$ & & & & & & \\
\hline $\mathrm{Na} / \mathrm{Cs}$ Final & $7.77 \mathrm{E}+04$ & $7.77 E+04$ & & & & & & \\
\hline Cs Kd Value & $-1.49 E+00$ & $-1.49 E+00$ & & & & & & \\
\hline Density & 0.5812 & 0.5812 & & & & & & \\
\hline Cs Lambda & $-8.63 E-01$ & $-8.63 \mathrm{E}-01$ & & & & & & \\
\hline ID Number & ZE1D & $\overline{\text { ZE1Q }}$ & ZE2D & ZE2Q & ZE3D & ZE3Q & ZE4D & ZE4Q \\
\hline Material & TIE-96 & TIE-96 & TIE-96 & TIE-96 & TIE-96 & TIE-96 & TIE-96 & TIE-96 \\
\hline [Na], Mol. & 5.01 & 5.01 & 5.01 & 5.01 & 5.01 & 5.01 & 5.01 & 5.01 \\
\hline F Factor & 0.8952 & 0.8952 & 0.8952 & 0.8952 & 0.8952 & 0.8952 & 0.8952 & 0.8952 \\
\hline $\mathrm{Na} / \mathrm{Cs}$ Start & $1.05 E+02$ & $1.05 \mathrm{E}+02$ & $1.05 E+03$ & $1.05 E+03$ & $1.14 E+04$ & $1.14 E+04$ & $7.84 E+04$ & $7.84 E+04$ \\
\hline $\mathrm{Na} / \mathrm{Cs}$ Final & $1.14 E+02$ & $1.12 E+02$ & $1.19 \mathrm{E}+03$ & $1.19 E+03$ & 1.29E+04 & $1.29 E+04$ & $8.83 E+04$ & $8.87 E+04$ \\
\hline Cs Kd Value & $1.36 E+01$ & $1.08 \mathrm{E}+01$ & $2.08 \mathrm{E}+01$ & $2.08 E+01$ & $2.07 E+01$ & $2.15 E+01$ & $2.09 E+01$ & $2.17 E+01$ \\
\hline Density & 0.7672 & 0.7672 & 0.7672 & 0.7672 & 0.7672 & 0.7672 & 0.7672 & 0.7672 \\
\hline Cs Lambda & $1.05 E+01$ & $8.32 \mathrm{E}+00$ & $1.60 \mathrm{E}+01$ & $1.60 \mathrm{E}+01$ & $1.59 E+01$ & $1.65 E+01$ & $1.60 \mathrm{E}+01$ & $1.67 \mathrm{E}+01$ \\
\hline & \multicolumn{5}{|c|}{ Phase IIExperiment: Multiple Cycle High DF, Cs lambdas } & & & \\
\hline & & & & & & & & \\
\hline ID Number & $\overline{C S 4 G}$ & CS4R & RF4G & RF4R & SL4G & SL4R & CP4G & CP4R \\
\hline Material & CS-100 & CS-100 & R-F (210) & $R-F(210)$ & SL-644. & SL-644 & IE-910 & IE-910 \\
\hline [Na], Mol. & 5.01 & 5.01 & 5.01 & 5.01 & 5.01 & 5.01 & 5.01 & 5.01 \\
\hline F Factor & 0.6671 & 0.6671 & 0.8109 & 0.8109 & 0.9436 & 0.9436 & 0.9841 & 0.9841 \\
\hline $\mathrm{Na} / \mathrm{Cs}$ Start & $1.07 \mathrm{E}+05$ & $1.07 E+05$ & $1.91 E+05$ & $1.91 \mathrm{E}+05$ & $4.78 E+05$ & $4.78 E+05$ & $5.69 E+05$ & $5.69 \mathrm{E}+05$ \\
\hline $\mathrm{Na} / \mathrm{Cs}$ Final & $1.52 \mathrm{E}+05$ & $1.50 \mathrm{E}+05$ & $3.14 \mathrm{E}+06$ & $3.26 \mathrm{E}+06$ & $3.27 E+07$ & $3.27 E+07$ & $2.14 E+07$ & $2.17 E+07$ \\
\hline Cs Kd Value & $1.00 E+01$ & $9.67 E+00$ & $3.06 \mathrm{E}+02$ & $3.18 \mathrm{E}+02$ & $1.15 E+03$ & $1.15 E+03$ & $6.12 E+02$ & $6.19 E+02$ \\
\hline Density & 0.2434 & 0.2434 & 0.3044 & 0.3044 & 0.2238 & 0.2238 & 0.7738 & 0.7738 \\
\hline Cs Lambda & $2.44 E+00$ & $2.35 \mathrm{E}+00$ & $9.31 \mathrm{E}+01$ & $9.69 \mathrm{E}+01$ & $2.58 E+02$ & $2.58 \mathrm{E}+02$ & $4.73 E+02$ & $4.79 E+02$ \\
\hline ID Number & CE4G & CE4R & ZE4G & ZE4R & & & & \\
\hline Material & \multicolumn{2}{|c|}{ IE-911, ( 0739-38B) } & TIE-96 & TIE-96 & & & & \\
\hline [Na], Mol. & 5.01 & 5.01 & 5.01 & 5.01 & & & & \\
\hline F Factor & 0.8695 & 0.8695 & 0.8952 & 0.8952 & & & & \\
\hline Na/Cs Start & $4.30 E+05$ & $4.30 \mathrm{E}+05$ & $8.56 E+04$ & $8.56 E+04$ & & & & \\
\hline $\mathrm{Na} / \mathrm{Cs}$ Final & $1.43 E+07$ & $1.43 E+07$ & $1.96 E+05$ & $1.96 \mathrm{E}+05$ & & & & \\
\hline Cs Kd Value & $6.15 E+02$ & $6.15 \mathrm{E}+02$ & $2.38 \mathrm{E}+01$ & $2.37 E+01$ & & & & \\
\hline Density & 1.1256 & 1.1256 & 0.7672 & 0.7672 & & & & \\
\hline \multirow[t]{2}{*}{ Cs Lambda } & $6.92 \mathrm{E}+02$ & $6.92 E+02$ & 1.82E+01 & $1.82 \mathrm{E}+01$ & & & & \\
\hline & \multicolumn{5}{|c|}{ Phase III: High Phase Ratio Experiment, Cs lambdas } & & & \\
\hline & & & & & & & & \\
\hline ID Number & RFOP & RFOU & SLOP & SLOU & CPOP & CPOU & $\overline{\text { CEOP }}$ & CEOU \\
\hline Material & R-F (210) & R-F (210) & SL-644 & SL-644 & IE-910 & IE-910 & \multicolumn{2}{|c|}{$11,(0739-38 \mathrm{~B})$} \\
\hline [Na], Mol. & 5.01 & 5.01 & 5.01 & 5.01 & 5.01 & 5.01 & 5.01 & 5.01 \\
\hline F Factor & 0.8109 & 0.8109 & 0.9436 & 0.9436 & 0.9841 & 0.9841 & 0.8695 & 0.8695 \\
\hline $\mathrm{Na} / \mathrm{Cs}$ Start & $7.84 E+04$ & $7.84 E+04$ & $7.84 E+04$ & $7.84 E+04$ & $7.84 E+04$ & $7.84 E+04$ & $7.84 E+04$ & $7.84 E+04$ \\
\hline $\mathrm{Na} / \mathrm{Cs}$ Final & $1.12 \mathrm{E}+05$ & $1.12 E+05$ & $1.59 E+05$ & $1.59 E+05$ & 1.71E+05 & $1.73 E+05$ & $1.34 E+05$ & $1.34 E+05$ \\
\hline Cs Kd Value & $2.52 E+02$ & $2.53 E+02$ & $5.32 \mathrm{E}+02$ & $5.33 E+02$ & $1.12 \mathrm{E}+03$ & $1.14 E+03$ & $7.31 \mathrm{E}+02$ & $7.28 \mathrm{E}+02$ \\
\hline Density & 3.04E-01 & $3.04 E-01$ & $2.24 \mathrm{E}-01$ & 2.24E-01 & 7.74E-01 & $7.74 E-01$ & $1.13 E+00$ & $1.13 E+00$ \\
\hline Cs Lambda & $7.67 \mathrm{E}+01$ & $7.69 \mathrm{E}+01$ & $1.19 E+02$ & $1.19 E+02$ & $8.66 E+02$ & $8.82 E+02$ & $8.23 E+02$ & $8.19 E+02$ \\
\hline
\end{tabular}




\begin{tabular}{|c|c|c|c|c|c|c|c|c|}
\hline & \multicolumn{5}{|c|}{ Phase TExperiment: Phase Ratio $=150 \mathrm{~mL}$, Sr lambdas } & & & \\
\hline ID Number & CS1D & CS1Q & CS2D & CS2Q & CS3D & $\operatorname{CS} 3 Q$ & CS4D & CS4Q \\
\hline Material & CS-100 & CS-100 & CS-10.0 & CS-100 & CS-100 & CS-100 & CS-100 & CS-100 \\
\hline$[\mathrm{Na}$, Mol. & 5.01 & 5.01 & 5.01 & 5.01 & 5.01 & 5.01 & 5.01 & 5.01 \\
\hline F Factor & 0.6671 & 0.6671 & 0.6671 & 0.6671 & 0.6671 & 0.6671 & 0.6671 & 0.6671 \\
\hline $\mathrm{Na} / \mathrm{Cs}$ Start & $1.05 \mathrm{E}+02$ & $1.05 E+02$ & $1.05 \mathrm{E}+03$ & $1.05 E+03$ & $1.14 \mathrm{E}+04$ & $1.14 \mathrm{E}+04$ & $7.84 \mathrm{E}+04$ & $7.84 E+04$ \\
\hline $\mathrm{Na} / \mathrm{Cs}$ Final & $1.12 E+02$ & $1.11 E+02$ & $1.10 \mathrm{E}+03$ & $1.10 \mathrm{E}+03$ & $1.18 \mathrm{E}+04$ & $1.19 \mathrm{E}+04$ & $8.43 E+04$ & $7.80 \mathrm{E}+04$ \\
\hline Sr Kd Value & $1.40 \mathrm{E}+01$ & $1.32 E+01$ & $1.02 \mathrm{E}+01$ & $9.51 E+00$ & $7.69 E+00$ & $1.07 E+01$ & $1.63 \mathrm{E}+01$ & $-1.29 E+00$ \\
\hline Density & 0.2434 & 0.2434 & 0.2434 & 0.2434 & 0.2434 & 0.2434 & 0.2434 & 0.2434 \\
\hline Sr Lambda & $3.40 \mathrm{E}+00$ & $3.22 E+00$ & $2.48 E+00$ & $2.32 \mathrm{E}+00$ & $1.87 \mathrm{E}+00$ & $2.60 \mathrm{E}+00$ & $3.97 \mathrm{E}+00$ & $-3.15 E-01$ \\
\hline ID Number & RF1D & RF1Q & RF2D & RF2Q & RF3D & RF3Q & RF4D & RF4Q \\
\hline Material & R-F (210) & R-F (210) & R-F (210) & R-F (210) & R-F (210) & $R-F(210)$ & R-F (210) & R-F (210) \\
\hline [Na], Mol. & 5.01 & 5.01 & 5.01 & 5.01 & 5.01 & 5.01 & 5.01 & 5.01 \\
\hline F Factor & 0.8109 & 0.8109 & 0.8109 & 0.8109 & 0.8109 & 0.8109 & 0.8109 & 0.8109 \\
\hline $\mathrm{Na} / \mathrm{Cs}$ Start & $1.05 E+02$ & $1.05 E+02$ & $1.05 \mathrm{E}+03$ & $1.05 \mathrm{E}+03$ & $1.14 E+04$ & $1.14 E+04$ & $7.84 E+04$ & $7.84 E+04$ \\
\hline $\mathrm{Na} / \mathrm{Cs}$ Final & $1.40 \mathrm{E}+02$ & $1.38 \mathrm{E}+02$ & $1.42 \mathrm{E}+03$ & $1.42 \mathrm{E}+03$ & $1.56 E+04$ & $1.55 \mathrm{E}+04$ & $1.04 \mathrm{E}+05$ & $1.03 E+05$ \\
\hline Sr Kd Value & $5.87 \mathrm{E}+01$ & $5.54 \mathrm{E}+01$ & $6.28 \mathrm{E}+01$ & $6.40 \mathrm{E}+01$ & $6.51 E+01$ & $6.34 \mathrm{E}+01$ & $5.69 \mathrm{E}+01$ & $5.40 \mathrm{E}+01$ \\
\hline Density & 0.3044 & 0.3044 & 0.3044 & 0.3044 & 0.3044 & 0.3044 & 0.3044 & 0.3044 \\
\hline Sr Lambda & $1.79 \mathrm{E}+01$ & $1.69 E+01$ & 1.91E+01 & $1.95 E+01$ & $1.98 \mathrm{E}+01$ & $1.93 E+01$ & $1.73 E+01$ & $1.64 E+01$ \\
\hline ID Number & $\overline{S L 1 D}$ & SL1Q & SL2D & SL2Q & SL3D & SL3Q & SL4D & SL4Q \\
\hline Material & SL-644 & SL-644 & SL-644 & SL-644 & SL-644 & SL-644 & SL-644 & SL-644 \\
\hline [Na], Mol. & 5.01 & 5.01 & 5.01 & 5.01 & 5.01 & 5.01 & 5.01 & 5.01 \\
\hline F Factor & 0.9436 & 0.9436 & 0.9436 & 0.9436 & 0.9436 & 0.9436 & 0.9436 & 0.9436 \\
\hline $\mathrm{Na} / \mathrm{Cs}$ Start & $1.05 \mathrm{E}+02$ & $1.05 \mathrm{E}+02$ & $1.05 E+03$ & $1.05 E+03$ & $1.14 \mathrm{E}+04$ & $1.14 \mathrm{E}+04$ & $7.84 E+04$ & $7.84 E+04$ \\
\hline $\mathrm{Na} / \mathrm{Cs}$ Final & $1.67 E+02$ & $1.65 \mathrm{E}+02$ & $1.59 \mathrm{E}+03$ & $1.62 E+03$ & $1.80 \mathrm{E}+04$ & $1.80 \mathrm{E}+04$ & $1.25 \mathrm{E}+05$ & $1.24 E+05$ \\
\hline Sr Kd Value & $9.25 \mathrm{E}+01$ & $8.82 \mathrm{E}+01$ & $8.03 E+01$ & $8.51 E+01$ & $9.03 E+01$ & $9.02 \mathrm{E}+01$ & $9.09 \mathrm{E}+01$ & $8.83 \mathrm{E}+01$ \\
\hline Density & 0.2238 & 0.2238 & 0.2238 & 0.2238 & 0.2238 & 0.2238 & 0.2238 & 0.2238 \\
\hline Sr Lambda & $2.07 E+01$ & $1.97 \mathrm{E}+01$ & $1.80 \mathrm{E}+01$ & $1.90 \mathrm{E}+01$ & $2.02 E+01$ & $2.02 E+01$ & $2.03 E+01$ & $1.98 \mathrm{E}+01$ \\
\hline ID Number & CP1D & CP1Q & CP2D & CP2Q & CP3D & CP3Q & CP4D & CP4Q \\
\hline Material & IE-910 & IE-910 & IE-910 & IE-910 & IE-910 & IE-910 & IE-910 & IE-910 \\
\hline [Na], Mol. & 5.01 & 5.01 & 5.01 & 5.01 & 5.01 & 5.01 & 5.01 & 5.01 \\
\hline F Factor & 0.9841 & 0.9841 & 0.9841 & 0.9841 & 0.9841 & 0.9841 & 0.9841 & 0.9841 \\
\hline $\mathrm{Na} / \mathrm{Cs}$ Start & $1.05 \mathrm{E}+02$ & $1.05 E+02$ & $1.05 E+03$ & $1.05 \mathrm{E}+03$ & $1.14 \mathrm{E}+04$ & $1.14 \mathrm{E}+04$ & $7.84 E+04$ & $7.84 \mathrm{E}+04$ \\
\hline $\mathrm{Na} / \mathrm{Cs}$ Final & $4.70 E+02$ & $4.45 E+02$ & $4.68 E+03$ & $4.82 E+03$ & $6.86 \mathrm{E}+04$ & $6.77 E+04$ & $1.28 E+05$ & $4.89 \mathrm{E}+05$ \\
\hline Sr Kd Value & $5.19 E+02$ & $4.83 E+02$ & $5.19 E+02$ & $5.38 \mathrm{E}+02$ & $7.20 E+02$ & $7.08 \mathrm{E}+02$ & $9.24 \mathrm{E}+01$ & $7.69 E+02$ \\
\hline Density & 0.7738 & 0.7738 & 0.7738 & 0.7738 & 0.7738 & 0.7738 & 0.7738 & 0.7738 \\
\hline Sr Lambda & $4.02 E+02$ & $3.73 E+02$ & $4.01 E+02$ & $4.16 E+02$ & $5.57 \mathrm{E}+02$ & $5.48 E+02$ & $7.15 \mathrm{E}+01$ & $5.95 \mathrm{E}+02$ \\
\hline ID Number & CE1D & CE1Q & CE2D & CE2Q & CE3D & CE3Q & CE4D & CE4Q \\
\hline Material & IE-911, ( & 739-38B) & IE-911, ( & 739-38B) & IE-911, ( & $739-38 B)$ & IE-911, ( & 739-38B) \\
\hline [Na], Mol. & 5.01 & 5.01 & 5.01 & 5.01 & 5.01 & 5.01 & 5.01 & 5.01 \\
\hline F Factor & 0.8695 & 0.8695 & 0.8695 & 0.8695 & 0.8695 & 0.8695 & 0.8695 & 0.8695 \\
\hline $\mathrm{Na} /$ Cs Start & $1.05 \mathrm{E}+02$ & $1.05 E+02$ & $1.05 E+03$ & $1.05 \mathrm{E}+03$ & $1.14 E+04$ & $1.14 E+04$ & $7.84 E+04$ & $7.84 E+04$ \\
\hline $\mathrm{Na} / \mathrm{Cs}$ Final & $7.19 E+02$ & $7.07 E+02$ & $7.33 E+03$ & $7.02 E+03$ & $7.11 \mathrm{E}+04$ & $7.37 E+04$ & $5.40 \mathrm{E}+05$ & $5.37 E+05$ \\
\hline Sr Kd Value & $9.74 E+02$ & $9.56 \mathrm{E}+02$ & $9.76 E+02$ & $9.28 E+02$ & $8.96 \mathrm{E}+02$ & $9.35 \mathrm{E}+02$ & $9.93 \mathrm{E}+02$ & $9.87 E+02$ \\
\hline Density & 1.1256 & 1.1256 & 1.1256 & 1.1256 & 1.1256 & 1.1256 & 1.1256 & 1.1256 \\
\hline Sr Lambda & $1.10 \mathrm{E}+03$ & $1.08 \mathrm{E}+03$ & $1.10 E+03$ & $1.04 E+03$ & $1.01 E+03$ & $1.05 E+03$ & $1.12 E+03$ & 1.11E+03 \\
\hline
\end{tabular}




\begin{tabular}{|c|c|c|c|c|c|c|c|c|}
\hline ID Number & TI4D & TI4Q & & & & & & \\
\hline Material & AS NaTi & AS NaTi & & & & & & \\
\hline [Na], Mol. & 5.01 & 5.01 & & & & & & \\
\hline F Factor & 1.0051 & 1.0051 & & & & & & \\
\hline $\mathrm{Na} /$ Cs Start & $7.84 E+04$ & $7.84 E+04$ & & & & & & \\
\hline $\mathrm{Na} / \mathrm{Cs}$ Final & $1.19 E+06$ & $1.20 E+06$ & & & & & & \\
\hline Sr Kd Value & $2.11 E+03$ & $2.13 E+03$ & & & & & & \\
\hline Density & 0.5812 & 0.5812 & & & & & & \\
\hline Sr Lambda & $1.23 E+03$ & $1.24 E+03$ & & & & & & \\
\hline ID Number & ZE1D & ZE1Q & ZE2D & ZE2Q & ZE3D & ZE3Q & ZE4D & ZE4Q \\
\hline Material & TIE-96 & TIE-96 & TIE-96 & TIE-96 & TIE-96 & TIE-96 & TIE-96 & TIE-96 \\
\hline [Na], Mol. & 5.01 & 5.01 & 5.01 & 5.01 & 5.01 & 5.01 & 5.01 & 5.01 \\
\hline F Factor & 0.8952 & 0.8952 & 0.8952 & 0.8952 & 0.8952 & 0.8952 & 0.8952 & 0.8952 \\
\hline $\mathrm{Na} / \mathrm{Cs}$ Start & $1.05 E+02$ & $1.05 \mathrm{E}+02$ & $1.05 E+03$ & $1.05 \mathrm{E}+03$ & $1.14 \mathrm{E}+04$ & $1.14 \mathrm{E}+04$ & $7.84 E+04$ & $7.84 E+04$ \\
\hline $\mathrm{Na} / \mathrm{Cs}$ Final & $: 2.77 \mathrm{E}+02$ & $2.56 \mathrm{E}+02$ & $2.74 E+03$ & $2.95 E+03$ & $2.95 E+04$ & $2.97 E+04$ & $2.03 E+05$ & $1.94 E+05$ \\
\hline Sr Kd Value & $2.75 E+02$ & $2.42 E+02$ & $2.57 E+02$ & $2.88 \mathrm{E}+02$ & $2.50 E+02$ & $2.53 E+02$ & $2.64 \mathrm{E}+02$ & $2.46 \mathrm{E}+02$ \\
\hline Density & 0.7672 & 0.7672 & 0.7672 & 0.7672 & 0.7672 & 0.7672 & 0.7672 & 0.7672 \\
\hline Sr Lambda & $2.11 E+02$ & $1.86 \mathrm{E}+02$ & $1.97 \mathrm{E}+02$ & $2.21 E+02$ & $1.92 E+02$ & $1.94 \mathrm{E}+02$ & $2.03 E+02$ & $1.88 E+02$ \\
\hline & Phase $\| E \times p$ & eriment: Mul & ple Cycle H & iDF, Srla & mbdas & & & \\
\hline ID Number & CS4G & CS4R & RF4G & RF4R & SL4G & SLAR & CP4G & CP4R \\
\hline Material & CS-100 & CS-100 & R-F (210) & R-F (210) & SL-644 & SL-644 & IE-910 & IE-910 \\
\hline [Na], Mol. & 5.01 & 5.01 & 5.01 & 5.01 & 5.01 & 5.01 & 5.01 & 5.01 \\
\hline F Factor & 0.6671 & 0.6671 & 0.8109 & 0.8109 & 0.9436 & 0.9436 & 0.9841 & 0.9841 \\
\hline $\mathrm{Na} /$ Cs Start & $1.07 E+05$ & $1.07 E+05$ & $1.91 E+05$ & $1.91 E+05$ & $4.78 E+05$ & $4.78 \mathrm{E}+05$ & $5.69 \mathrm{E}+05$ & $5.69 E+05$ \\
\hline $\mathrm{Na} / \mathrm{Cs}$ Final & $1.52 E+05$ & $1.50 E+05$ & $3.14 E+06$ & $3.26 E+06$ & $3.27 E+07$ & $3.27 E+07$ & $2.14 E+07$ & $2.17 E+07$ \\
\hline Sr Kd Value & $1.98 \mathrm{E}+00$ & $1.84 \mathrm{E}+00$ & $1.74 E+01$ & $1.89 \mathrm{E}+01$ & $7.15 E+01$ & $7.15 E+01$ & $2.34 \mathrm{E}+02$ & $2.32 E+02$ \\
\hline Density & 0.2434 & 0.2434 & 0.3044 & 0.3044 & 0.2238 & 0.2238 & 0.7738 & 0.7738 \\
\hline Sr Lambda & 4.82E-01 & $4.48 E-01$ & $5.30 \mathrm{E}+00$ & $5.75 E+00$ & $1.60 \mathrm{E}+01$ & $1.60 \mathrm{E}+01$ & $1.81 \mathrm{E}+02$ & $1.80 E+02$ \\
\hline ID Number & CE4G & CE4R & ZE4G & ZE4R & & & & \\
\hline Material & IE-911, ( & $739-38 \mathrm{~B})$ & TIE-96. & TIE-96 & & & & \\
\hline$[\mathrm{Na}], \mathrm{Mol}$. & 5.01 & 5.01 & 5.01 & 5.01 & & & & \\
\hline F Factor & 0.8695 & 0.8695 & 0.8952 & 0.8952 & & & & \\
\hline Na/Cs Start & $4.30 E+05$ & $4.30 E+05$ & $8.56 E+04$ & $8.56 E+04$ & & & & \\
\hline $\mathrm{Na} / \mathrm{Cs}$ Final & $1.43 E+07$ & $1.43 E+07$ & $1.96 \mathrm{E}+05$ & $1.96 \mathrm{E}+05$ & & & & \\
\hline Sr Kd Value & $6.68 \mathrm{E}+02$ & $6.41 E+02$ & $2.57 E+02$ & $2.38 E+02$ & & & & \\
\hline Density & 1.1256 & 1.1256 & 0.7672 & 0.7672 & & & & \\
\hline Sr Lambda & $7.52 \mathrm{E}+02$ & $7.21 \mathrm{E}+02$ & $1.97 \mathrm{E}+02$ & $1.83 \mathrm{E}+02$ & & & & \\
\hline & Phase III:H & hh Phase Ra & o Experime & it Srlambd & & & & \\
\hline & & & & & & & & \\
\hline ID Number & RFOP & RFOU & SLOP & SLOU & CPOP & CPOU & CEOP & CEOU \\
\hline Material & R-F (210) & R-F (210) & SL-644 & SL-644 & IE-910 & IE-910 & \multicolumn{2}{|c|}{ IE-911, (0739-38B) } \\
\hline$[\mathrm{Na}], \mathrm{Mol}$. & 5.01 & 5.01 & 5.01 & 5.01 & 5.01 & 5.01 & 5.01 & 5.01 \\
\hline F Factor & 0.8109 & 0.8109 & 0.9436 & 0.9436 & $\overline{0.9841}$ & 0.9841 & 0.8695 & 0.8695 \\
\hline $\mathrm{Na} / \mathrm{Cs}$ Start & $7.84 E+04$ & $7.84 E+04$ & $7.84 E+04$ & $7.84 E+04$ & $7.84 E+04$ & $7.84 E+04$ & $7.8 d E+04$ & $7.84 E+04$ \\
\hline $\mathrm{Na} /$ Cs Final & $1.12 \mathrm{E}+05$ & $1.12 E+05$ & $1.59 \mathrm{E}+05$ & $1.59 E+05$ & $1.71 E+05$ & $1.73 \mathrm{E}+05$ & $1.34 E+05$ & $1.34 E+05$ \\
\hline Sr Kd Value & $1.23 E+02$ & $1.07 E+02$ & $8.47 E+01$ & $7.51 E+01$ & $9.20 E+02$ & $8.75 \mathrm{E}+02$ & $8.09 E+02$ & $7.85 E+02$ \\
\hline Density & 0.3044 & 0.3044 & 0.2238 & 0.2238 & 0.7738 & 0.7738 & 1.1256 & 1.1256 \\
\hline Sr Lambda & $3.76 \mathrm{E}+01$ & $3.25 \mathrm{E}+01$ & $1.90 E+01$ & $1.68 \mathrm{E}+01$ & $7.12 E+02$ & $6.77 \mathrm{E}+02$ & $9.10 E+02$ & $8.84 E+02$ \\
\hline
\end{tabular}




\section{Appendix D}

Chromium, Zirconium, and Strontium ICP $\lambda$ Values for the Actual Waste Experiments 



\begin{tabular}{|c|c|c|c|c|c|c|c|c|c|c|c|c|c|c|c|c|}
\hline Sample & A1 & B & Be & $\mathbf{C a}$ & $\mathrm{Cr}$ & $\mathbf{K}$ & Mo & $\mathrm{Na}$ & NI & $P$ & $\overline{\mathrm{Pb}}$ & Si & $5 r$ & $\pi$ & $\mathrm{Zn}$ & $\mathrm{zr}$ \\
\hline CS-4.D & 11498 & 78.45 & & & 99.16 & 17424 & 25.04 & 102655 & & 400.74 & & & 1.02 & & 423 & 3.37 \\
\hline CS-4-Q & 13019 & 140.77 & 0.93 & 47.13 & 109.51 & 19018 & 30.33 & $>99900$ & 6.89 & 453.40 & 21.39 & 113.08 & 1.17 & & 7.13 & 3.94 \\
\hline CS.4.Q & 13033 & 144.73 & & 155.01 & 107.08 & 18903 & 30.17 & 117898 & & 444.50 & & & & & & \\
\hline CS-Std & 882 & 37.18 & \#DIV/OI & 76.28 & 5.41 & 889 & 3.01 & 10778 & \#DIV/OI & 28.19 & \#DIV/OI & \#DIV/OI & 0.11 & HDIV/OI & 2.05 & 0.40 \\
\hline CS-Avg & 12517 & 121.32 & 0.93 & 101.07 & 105.25 & 18449 & 28.51 & 110276 & 6.89 & 432.88 & 21.39 & 113.08 & 1.10 & \#DIV/OI & 5.68 & 3.66 \\
\hline$R F=4 \cdot D$ & 12304 & 82.14 & 1.00 & & 65.09 & 19268 & 26.92 & 108385 & 7.40 & 432.88 & & & & & 5.06 & 307 \\
\hline$R F=4-Q$ & 12877 & 132.42 & & & 65.74 & 19520 & 29.62 & 116501 & & 425.23 & & & & & & \\
\hline$R F-4-Q$ & 12748 & 129.74 & 1.02 & & 66.22 & 19560 & 29.70 & $>99900$ & 8.10 & 444.65 & 21.90 & 99.54 & 0.88 & & 5.93 & 3.42 \\
\hline RF-Std & 300 & 28.29 & 0.01 & \#DIV/OI & 0.57 & 159 & 1.58 & 5739 & 0.49 & 9.78 & ADIVIOI & \#DIV/OI & \#DIVIOI & \#DIV/OI & 062 & 0.25 \\
\hline RF-Avg & 12643 & 114.77 & 1.01 & \#DIVIOI & 65.68 & 19449 & 28.75 & 112443 & 7.75 & 434.25 & 21.90 & 99.54 & 0.88 & \#DIVIOI & 5.50 & 3.25 \\
\hline SL-4-D & 12310 & 130.07 & & & 56.71 & 18153 & 26.68 & 108247 & 6.05 & 429.68 & & & & & 5.58 & 2.34 \\
\hline SL-4.Q & 12940 & 131.62 & & & 58.22 & 18531 & 29.48 & 116335 & & 441.57 & & & & & & \\
\hline$S L-4-Q$ & 12636 & 127.74 & 0.95 & 31.95 & 58.57 & 18345 & 29.68 & $>99900$ & 7.21 & 443.45 & 20.39 & 100.11 & 0.77 & & 5.52 & 2.78 \\
\hline SL-Std & 315 & 1.95 & HDIVIOI & \#DIV/OI & 0.99 & 189 & 1.68 & 5719 & 0.82 & 7.47 & HDIV/OI & \#DIVIOI & \#DIV/O! & \#DIVIOI & 004 & 0.31 \\
\hline SL-Avg & 12629 & 129.81 & 0.95 & 31.95 & 57.83 & 18343 & 28.61 & 112291 & 6.63 & 438.23 & 20.39 & 100.11 & 0.77 & \#DIVIOI & 5.55 & 2.56 \\
\hline CP-4-D & 12605 & 146.15 & 1.11 & & 109.56 & 18438 & 27.72 & 111028 & 8.83 & 441.07 & 21.68 & & & 4.17 & 5.43 & 4.09 \\
\hline CP-4-Q & 12980 & 140.29 & & & 109.70 & 18635 & 30.48 & 117334 & & 442.25 & & & & 4.37 & & \\
\hline CP.4-Q & 12936 & 138.57 & 1.12 & 36.57 & 111.02 & 18744 & 30.18 & $>99900$ & 9.30 & 447.73 & 30.42 & 117.60 & & 4.44 & 6.80 & 4.39 \\
\hline CP-SId & 205 & 3.97 & 0.01 & \#DIVIOI & 0.81 & 155 & 1.51 & 4459 & 0.33 & 3.55 & 6.18 & HDIV/OI & \#DIV/OI & 0.14 & 0.97 & 0.21 \\
\hline CP.Avg & 12841 & 141.67 & 1.12 & 36.57 & 110.09 & 18606 & 29.46 & 114181 & 9.07 & 443.68 & 26.05 & 117.60 & \#DIVIOI & 4.33 & 6.12 & 4.24 \\
\hline CE-4.D & 12832 & 139.26 & 1.04 & & 110.47 & 19036 & 27.72 & 114971 & 8.54 & 448.60 & & 113.23 & & 2.01 & 4.69 & 10.39 \\
\hline CE-4-Q & 12802 & 141.49 & & & 107.93 & 18222 & 29.17 & 115272 & & 433.33 & & & & & & 9.63 \\
\hline CE-4.Q & 12579 & 138.18 & 1.03 & 30.11 & 108.07 & 18207 & 29.04 & $>99900$ & 9.38 & 437.94 & 19.28 & 108.23 & & 2.29 & 5.25 & 10.40 \\
\hline CE-SId & 138 & 7.69 & 0.01 & \#DIVIOI & 1.43 & 474 & 0.80 & 213 & 0.59 & 7.83 & \#DIV/OI & 3.54 & \#DIV/OI & 0.20 & 0.40 & 0.44 \\
\hline CE-Avg & 12738 & 139.64 & 1.04 & 30.11 & 108.82 & 18488 & 28.64 & 115121 & 8.96 & 439.96 & 19.28 & 110.73 & \#DIV/OI & 2.15 & 4.97 & 10.14 \\
\hline TI-4-D & 13034 & 152.80 & 1.11 & & 111.77 & 19428 & 27.24 & 116791 & 8.22 & 450.54 & & 116.90 & & 1.03 & 4.12 & \\
\hline$T I .4 . Q Q$ & 12589 & 130.38 & & & 107.21 & 18396 & 30.42 & 112749 & & 446.20 & & & & & & \\
\hline$T 1-4 . Q$ & 12640 & 130.34 & 1.09 & & 108.48 & 18412 & 29.61 & $>99900$ & 9.34 & 444.70 & 16.81 & 97.56 & & 1.51 & 4.33 & \\
\hline Ti-Std & 244 & 12.96 & 0.01 & HDIV/OI & 2.35 & 591 & 1.65 & 2859 & 0.79 & 3.03 & \#DIVIOI & 13.68 & \#DIV/OI & 0.34 & 0.15 & \#DIV/OI \\
\hline TI-Avg & 12754 & 137.84 & 1.10 & \#DIV/OI & 109.15 & 18745 & 29.09 & 114770 & 8.78 & 447.15 & 16.81 & 107.23 & \#DIV/OI & 1.27 & 4.23 & \#DIV/OI \\
\hline$Z E \cdot 4 \cdot D$ & 13032 & 146.98 & 1.08 & & 113.56 & 19394 & 27.21 & 116099 & 7.94 & 479.65 & & 353.37 & & 1.14 & 4.43 & \\
\hline ZE-4-Q & 13004 & 145.42 & & & 109.13 & 18433 & 30.52 & 117971 & & 464.16 & & 334.18 & & & & \\
\hline ZE-4-Q & 12720 & 140.90 & 1.10 & & 109.30 & 18372 & 30.00 & $>99900$ & 9.50 & 465.70 & 23.90 & 336.50 & 0.60 & 1.40 & 5.00 & \\
\hline ZE-Std & 173 & 3.16 & 0.01 & \#DIVIOI & 2.51 & 573 & 1.78 & 1324 & 1.10 & 8.53 & \#DIVIOI & 10.47 & \#DIV/OI & 0.18 & 0.40 & \#DIV/OI \\
\hline ZE-Avg & 12919 & 144.43 & 1.09 & \#DIV/OI & 110.66 & 18733 & 29.24 & 117035 & 8.72 & 469.84 & 23.90 & 341.35 & 0.60 & 1.27 & 4.72 & \#DIV/OI \\
\hline BL-4-D & 12820 & 156.60 & 1.10 & & 111.50 & 18932 & 28.00 & 115573 & 8.20 & 436.50 & 12.50 & 107.20 & 1.10 & & 5.10 & 4.50 \\
\hline$B L-4 \cdot a$ & 12733 & 142.70 & & & 109.40 & 18410 & 29.70 & 114864 & & 435.50 & 32.00 & & & & & 5.30 \\
\hline$B L-4 \cdot Q$ & 12621 & 139.30 & 1.10 & & 108.50 & 18367 & 29.80 & 399900 & 9.30 & 441.90 & 35.40 & 111.70 & 1,20 & & 5.10 & 5.40 \\
\hline BL-Std & 99 & 9.17 & & \#DIV/OI & 1.54 & $314^{\circ}$ & 1.01 & 501 & 0.78 & 3.44 & 12.36 & 3.18 & 0.07 & \#DIVIOI & & 0.49 \\
\hline BL-Avg & 12725 & 146.20 & 1.10 & HDIVIOI. & 109.80 & 78569 & 29.17 & 115218 & 8.75 & 437.97 & 26.63 & 109.45 & 1.15 & HDIVIOI & 5.10 & 5.07 \\
\hline Org-Avg & 12596 & 121.96 & 0.98 & 78.03 & 76.26 & 18747 & 28.62 & 111670 & 7.13 & 435.12 & 21.23 & 104.24 & 0.96 & HDIVIOI & 5.58 & 3.15 \\
\hline Org.std & 495 & 24.27 & 0.04 & 67.10 & 22.18 & 702 & .1 .90 & 6126 & 0.75 & 15.57 & 0.77 & 7.66 & 0.17 & FDIVIOI & 0.96 & 0.56 \\
\hline Inorg-Avg & 12813 & 140.90 & 1.09 & 33.34 & 109.68 & 18643 & 29.11 & 115277 & 8.88 & 450.16 & 22.42 & 197.20 & 0.60 & 2.48 & 5.01 & 7.78 \\
\hline Inorg-std & 182 & 6.50 & 0.03 & 4.57 & 1.80 & 425 & 1.31 & 2360 & 0.59 & 13.28 & 5.20 & 119.66 & \#DIVIOI & 1.44 & 0.86 & 3.25 \\
\hline All-Avg & $\overline{12721}$ & 134.46 & 1.06 & 60.15 & 97.16 & 18673 & 28.93 & 113917 & 8.28 & 442.99 & 23.24 & 162.25 & 0.96 & 2.48 & 5.23 & 5.22 \\
\hline All-Std & 336 & 18.25 & 0.06 & 53.44 & 21.13 & 520 & 1.49 & 4285 & 1.04 & 14.96 & 6.82 & 102.39 & 0.22 & 1.44 & 0.85 & 2.81 \\
\hline
\end{tabular}




\begin{tabular}{|c|c|c|c|c|c|c|c|c|c|c|c|c|c|c|}
\hline \multirow{2}{*}{\multicolumn{15}{|c|}{ Phase I Experiment: ICP metals Kd's and L }} \\
\hline & & & & & & & & & & & & & & \\
\hline ID Number & $\operatorname{CS4D}$ & $\operatorname{cs} 4 Q-1$ & $\operatorname{CS} 40-2$ & RF4D & RF40-1 & RF4Q-2 & SL4D & $5140-1$ & SL40-2 & & & & & \\
\hline Material & CS-100 & CS-100 & CS-100 & $R-F(210)$ & R-F (210) & $R-F(210)$ & SL-644 & SL-644 & SL-644 & & & & & \\
\hline Tracer & CrICP & CrICP & CrICP & CrICP & CrICP & CrICP & CrICP & CrICP & CrICP & & & & & \\
\hline [Na], Mol. & $5.000 E+00$ & $5.000 E+00$ & $5.000 \mathrm{E}+00$ & $5.000 \mathrm{E}+00$ & $5.000 E+00$ & $5.000 E+00$ & $5.000 \mathrm{E}+00$ & $5.000 \mathrm{E}+00$ & $5.000 E+00$ & & & & & \\
\hline F Factor & $6.671 \mathrm{E}-01$ & $6.671 \mathrm{E}-01$ & $6.671 \mathrm{E}-01$ & $8.109 \mathrm{E}-01$ & $8.109 \mathrm{E}-01$ & $8.109 \mathrm{E}-01$ & $9.436 \mathrm{E}-01$ & $9.436 \mathrm{E}-01$ & $9.436 \mathrm{E}-01$ & & & & & \\
\hline $\mathrm{Na} / \mathrm{Cr}$ Start & $2.368 \mathrm{E}+03$ & $2.368 E+03$ & $2.368 \mathrm{E}+03$ & $2.368 E+03$ & $2.368 \mathrm{E}+03$ & $2.368 E+03$ & $2.368 \mathrm{E}+03$ & $2.368 E+03$ & $2.368 E+03$ & & & & & \\
\hline $\mathrm{Na} / \mathrm{Cr}$ Final & $2.622 E+03$ & $2.374 E+03$ & $2.428 \mathrm{E}+03$ & $3.994 E+03$ & $3.955 \mathrm{E}+03$ & $3.926 \mathrm{E}+03$ & $4.584 E+03$ & $4.465 \mathrm{E}+03$ & $4.439 E+03$ & & & & & \\
\hline Kd Value & $2.332 E+01$ & $5.755 \mathrm{E}-01$ & $5.520 \mathrm{E}+00$ & $1.194 \mathrm{E}+02$ & $1.165 \mathrm{E}+02$ & $1.144 \mathrm{E}+02$ & $1.428 \mathrm{E}+02$ & $1.352 E+02$ & $1.334 E+02$ & & & & & \\
\hline Density & $2.434 \mathrm{E}-01$ & $2.434 \mathrm{E}-01$ & $2.434 \mathrm{E}-01$ & $3.044 \mathrm{E}-01$ & $3.044 \mathrm{E}-01$ & 3.044E-01 & $2.238 \mathrm{E}-01$ & $2.238 \mathrm{E}-01$ & $2.238 \mathrm{E}=01$ & & & & & \\
\hline \multirow[t]{3}{*}{ Lambda Valu } & $5.675 E+00$ & $1.401 \mathrm{E}-01$ & $1.344 E+00$ & $3.634 \mathrm{E}+01$ & $3.546 \mathrm{E}+01$ & $3.482 \mathrm{E}+01$ & $3.196 \mathrm{E}+01$ & $3.025 \mathrm{E}+01$ & $2.987 \mathrm{E}+01$ & & & & & \\
\hline & & & & & & & & & & & & & & \\
\hline & & & & & & & & & & & & & & \\
\hline ID Number & CS4D & $\operatorname{cs} 4 Q$ & RF4Q & SL4Q & CP4Q & CE4Q & $T 14 \bar{Q}$ & ZE4Q & BL4-Avg & & & & & \\
\hline Material & CS-100 & CS-100 & $R-F(210)$ & SL-644 & IE-910 & IE-911 (38b) & NaTi & TIE-96 & Blank & & & & & \\
\hline Tracer & SrICP & SrICP & SrICP & SrICP & SrICP & SrICP & SrICP & SrICP & SrICP & & & & & \\
\hline [Na], Mol. & $5.000 \mathrm{E}+00$ & $5.000 E+00$ & $5.000 E+00$ & $5.000 E+00$ & $5.000 \mathrm{E}+00$ & $5.000 E+00$ & $5.000 E+00$ & $5.000 \mathrm{E}+00$ & $5.000 \mathrm{E}+00$ & & & & & \\
\hline F Factor & $6.671 \mathrm{E}-01$ & $6.671 \mathrm{E}-01$ & $8.109 \mathrm{E}-01$ & $9.436 \mathrm{E}-01$ & $9.841 \mathrm{E}-01$ & $8.695 \mathrm{E}-01$ & $1.005 \mathrm{E}+00$ & $8.952 E-01$ & & & & & & \\
\hline $\mathrm{Na} / \mathrm{Sr}$ Start & $3.810 E+05$ & $3.810 E+05$ & $3.810 E+05$ & $3.810 \mathrm{E}+05$ & $3.810 E+05$ & $3.810 E+05$ & $3.810 \mathrm{E}+05$ & $3.810 E+05$ & $3.810 E+05$ & & & & & \\
\hline $\mathrm{Na} / \mathrm{Sr}$ Final & $4.295 E+05$ & $3.744 E+05$ & $4.978 E+05$ & $5.690 E+05$ & $8.762 E+05$ & $8.762 E+05$ & $8.762 E+05$ & $7.302 E+05$ & $3.810 E+05$ & & & & & \\
\hline Kd Value & $2.770 E+01$ & $-3.715 E+00$ & $5.332 E+01$ & $7.529 \mathrm{E}+01$ & $1.911 E+02$ & $2.196 E+02$ & $1.940 \mathrm{E}+02$ & $1.523 E+02$ & \#DIV/OI & & & & & \\
\hline Density & $2.434 \mathrm{E}-01$ & $2.434 \mathrm{E}-01$ & $3.044 \mathrm{E}-01$ & $2.238 \mathrm{E}-01$ & $7.738 \mathrm{E}-01$ & $1.126 E+00$ & $5.812 \mathrm{E}-01$ & $7.672 \mathrm{E}-01$ & $2.190 E+01$ & & & & & \\
\hline \multirow[t]{2}{*}{ Lambda Valu } & $6.741 E+00$ & $-9.041 \mathrm{E}-01$ & $1.623 \mathrm{E}+01$ & $1.685 \mathrm{E}+01$ & $1.478 \mathrm{E}+02$ & $2.471 E+02$ & $1.128 \mathrm{E}+02$ & $1.168 \mathrm{E}+02$ & \#DIV/OI & & & & & \\
\hline & & & & & & & & & & & & & & \\
\hline ID Number & CS4D & CS4Q & RF4Q & RF4Q & SL4Q & SL4Q & CP4Q & CP4Q & CE4Q & CE4Q & CE4Q & $T 14 Q$ & ZE4Q & BL4-Avg \\
\hline Material & CS-100 & CS-100 & R-F (210) & R-F (210) & $\mathrm{SL}-644$ & SL-644 & IE-910 & IE-910 & EE-911 (38b) & IE-911 (38b) & IE-911 (38b) & $\mathrm{NaTi}$ & TIE-96 & Blank \\
\hline Tracer & Zr ICP & Zr ICP & ZriCP & ZrICP & ZrICP & $\mathrm{ZrICP}$ & ZriCP & ZrICP & ZrICP & ZrICP & ZrICP & ZrICP & ZrICP & Zr ICP \\
\hline [Na], Mol. & $5.000 \mathrm{E}+00$ & $5.000 E+00$ & $5.000 \mathrm{E}+00$ & $5.000 E+00$ & $5.000 \mathrm{E}+00$ & $5.000 \mathrm{E}+00$ & $5.000 E+00$ & $5.000 E+00$ & $5.000 E+00$ & $5.000 E+00$ & $5.000 E+00$ & $5.000 \mathrm{E}+00$ & $5.000 E+00$ & $5.000 E+00$ \\
\hline F Factor & $6.671 \mathrm{E}-01$ & $6.671 \mathrm{E}-01$ & $8.109 \mathrm{E}-01$ & $8.109 \mathrm{E}-01$ & $9.436 E-01$ & $9.436 \mathrm{E}-01$ & $9.841 \mathrm{E}-01$ & $9.841 \mathrm{E}-01$ & 8.695E-01 & $8.695 \mathrm{E}-01$ & $8.695 \mathrm{E}-01$ & $1.005 E+00$ & $8.952 \mathrm{E}-01$ & \\
\hline Na/Zr Start & $8.996 E+04$ & $8.996 E+04$ & $8.996 \mathrm{E}+04$ & $8.996 E+04$ & $8.996 \mathrm{E}+04$ & $8.996 E+04$ & $8.996 E+04$ & $8.996 E+04$ & $8.996 E+04$ & $8.996 E+04$ & $8.996 E+04$ & $8.996 \mathrm{E}+04$ & $8.996 E+04$ & $8.996 E+04$ \\
\hline $\mathrm{Na} / \overline{\mathrm{r}}$ Final & $1.353 E+05$ & $1.158 \mathrm{E}+05$ & $1.486 E+05$ & $1.334 E+05$ & $1.949 E+05$ & $1.641 E+05$ & $1.115 E+05$ & $1.039 \mathrm{E}+05$ & $4.390 E+04$ & $4.736 E+04$ & $4.386 \mathrm{E}+04$ & $4.561 E+05$ & $4.561 \mathrm{E}+05$ & $8.996 E+04$ \\
\hline Kd Value & $1.096 \mathrm{E}+02$ & $6.232 E+01$ & $1.132 \mathrm{E}+02$ & $8.385 E+01$ & $1.780 E+02$ & $1.257 \mathrm{E}+02$ & $3.522 \mathrm{E}+01$ & $2.277 \mathrm{E}+01$ & $-8.648 \mathrm{E}+01$ & $-7.997 E+01$ & $-8.656 E+01$ & $6.075 E+02$ & $6.762 \mathrm{E}+02$ & \#DIV/OI \\
\hline Density & $2.434 \mathrm{E}-01$ & $2.434 E-01$ & $3.044 \mathrm{E}-01$ & $3.044 \mathrm{E}-01$ & $2.238 \mathrm{E}-01$ & $2.238 E-01$ & $7.738 \mathrm{E}-01$ & $7.738 \mathrm{E}-01$ & $1.126 \mathrm{E}+00$ & $1.126 \mathrm{E}+00$ & $1.126 \mathrm{E}+00$ & $5.812 E-01$ & $7.672 \mathrm{E}-01$ & \\
\hline Lambda Valu & $2.668 E+01$ & $1.517 \mathrm{E}+01$ & $3.446 \mathrm{E}+01$ & $2.552 \mathrm{E}+01$ & $3.984 E+01$ & $2.813 \mathrm{E}+01$ & $2.725 \mathrm{E}+01$ & $1.762 \mathrm{E}+01$ & $-9.734 E+01$ & $-9.002 E+01$ & $-9.743 E+01$ & $3.531 E+02$ & $5.188 \mathrm{E}+02$ & \#DIV/OI \\
\hline & & & & & & & & & & & & & & \\
\hline
\end{tabular}




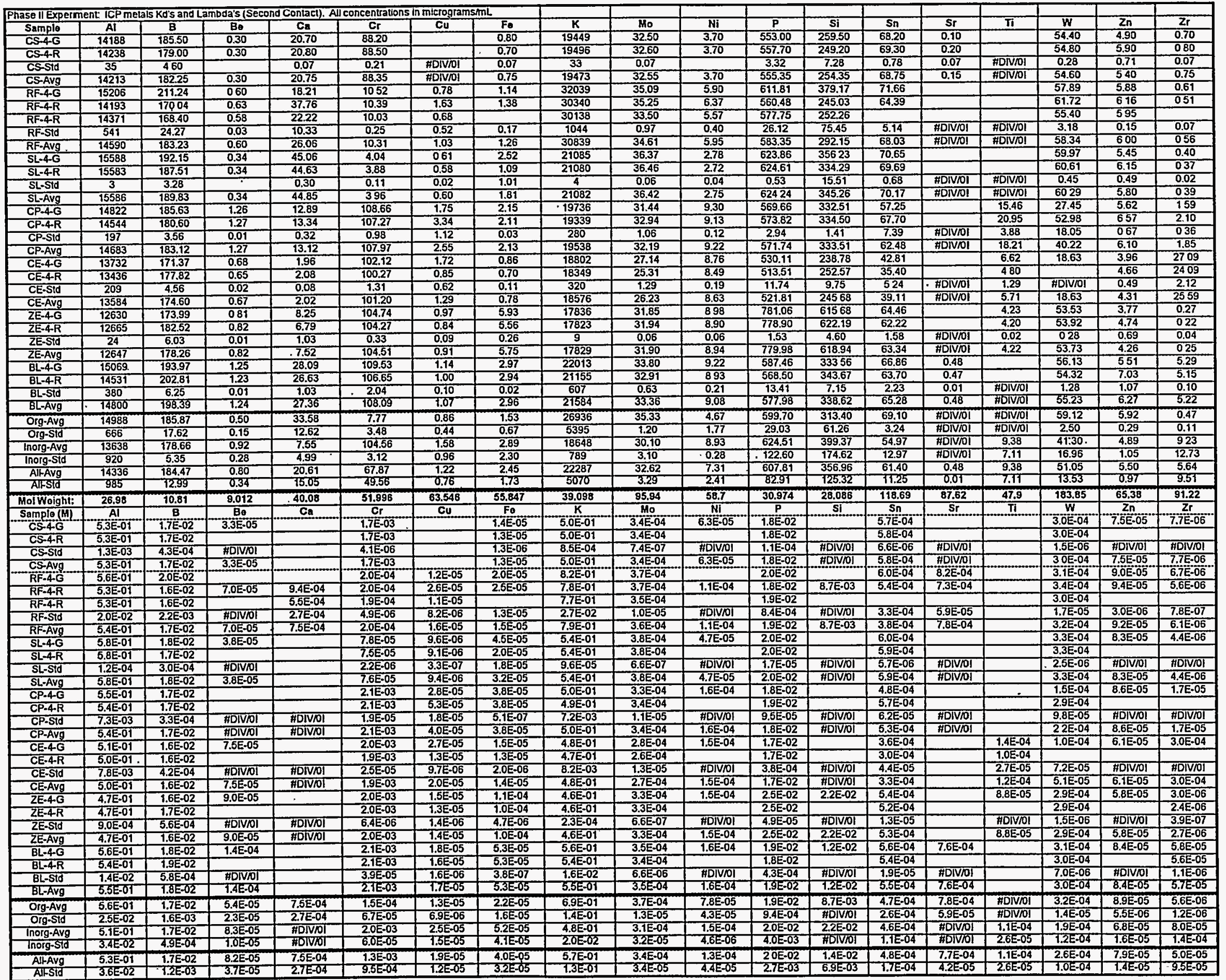


Excel 4.0 File: HOT_ICP2.XLS

Page 1 of 2

\begin{tabular}{|c|c|c|c|c|c|c|c|c|c|c|c|c|}
\hline ID Number & CS4G & CS4R & RFAG & R्4R-1 & $\mathrm{R} F 4 \mathrm{R}-2$ & SLAG & SL4R & $\overline{\text { CE4G }}$ & $\overline{\mathrm{CE} 4 \mathrm{R}}$ & ZE4R & & \\
\hline Material & CS-100 & CS-100 & R-F $(210)$ & $\mathrm{R}-\mathrm{F}(210)$ & R-F (210) & SL-644 & SL-644 & IE-911 & IE-911 & TIE-96 & & \\
\hline Tracer & CrICP & $\overline{\mathrm{Cr} I \mathrm{ICP}}$ & Cr ICP & $\overline{\mathrm{Cr} \text { ICP }}$ & Cr ICP & Cr ICP & Cr ICP & $\overline{\mathrm{Cr} I \mathrm{ICP}}$ & $\overline{\mathrm{Cr} I \mathrm{ICP}}$ & $\mathrm{Cr}$ ICP & & \\
\hline [Na], Mol. & $5.00 \mathrm{E}+00$ & $5.00 \mathrm{E}+00$ & $5.00 \mathrm{E}+00$ & $5.00 \mathrm{E}+00$ & $5.00 \mathrm{E}+00$ & $5.00 \mathrm{E}+00$ & $5.00 \mathrm{E}+00$ & $5.00 \mathrm{E}+00$ & $5.00 \mathrm{E}+00$ & $5.00 \mathrm{E}+00$ & $\leq$ & \\
\hline F Factor & $6.67 \mathrm{E}-01$ & $6.67 \mathrm{E}-01$ & $6.67 \mathrm{E}-01$ & $6.67 \mathrm{E}-01$ & $6.67 \mathrm{E}-01$ & $8.11 \mathrm{E}-01$ & $8.11 \mathrm{E}-01$ & $8.69 \mathrm{E}-01$ & $8.69 \mathrm{E}-01$ & $8.95 \mathrm{E}-01$ & & \\
\hline $\mathrm{Na} / \mathrm{Cr}$ Start & $2.47 \mathrm{E}+03$ & $2.47 \mathrm{E}+03$ & $3.96 \mathrm{E}+03$ & $3.96 \mathrm{E}+03$ & $3.96 \mathrm{E}+03$ & $4.50 \mathrm{E}+03$ & $4.50 \mathrm{E}+03$ & $2.39 \mathrm{E}+03$ & $2.39 \mathrm{E}+03$ & $2.35 \mathrm{E}+03$ & . & \\
\hline $\mathrm{Na} / \mathrm{Cr}$ Final & $2.95 \mathrm{E}+03$ & $2.94 \mathrm{E}+03$ & $2.47 \mathrm{E}+04$ & $2.50 \mathrm{E}+04$ & $2.59 \mathrm{E}+04$ & $6.44 \mathrm{E}+04$ & $6.70 \mathrm{E}+04$ & $2.55 \mathrm{E}+03$ & $2.59 \mathrm{E}+03$ & $2.48 \mathrm{E}+03$ & & \\
\hline DF Value & $1.19 \mathrm{E}+00$ & $1.19 \mathrm{E}+00$ & $6.24 E+00$ & $6.32 E+00$ & $6.55 \mathrm{E}+00$ & $1.43 \mathrm{E}+01$ & $1.49 \mathrm{E}+01$ & $1.07 \mathrm{E}+00$ & $1.09 \mathrm{E}+00$ & $1.06 \mathrm{E}+00$ & & \\
\hline Kd Value & $4.68 \mathrm{E}+00$ & $4.58 \mathrm{E}+00$ & $1.26 \mathrm{E}+02$ & $1.28 \mathrm{E}+02$ & $1.34 \mathrm{E}+02$ & $2.65 \mathrm{E}+02$ & $2.77 \mathrm{E}+02$ & $1.25 \mathrm{E}+00$ & $1.63 \mathrm{E}+00$ & $1.04 \mathrm{E}+00$ & & \\
\hline Density & $2.43 \mathrm{E}-01$ & $2.43 \mathrm{E}-01$ & $3.04 \mathrm{E}-01$ & $3.04 \mathrm{E}-01$ & $3.04 \mathrm{E}-01$ & $2.24 \mathrm{E}-01$ & $2.24 \mathrm{E}-01$ & $1.13 \mathrm{E}+00$ & $1.13 \mathrm{E}+00$ & $7.67 \mathrm{E}-01$ & & \\
\hline Lambda Value & $1.14 \mathrm{E}+00$ & $1.11 \mathrm{E}+00$ & $3.85 \mathrm{E}+01$ & $3.90 \mathrm{E}+01$ & $4.07 \mathrm{E}+01$ & $5.93 \mathrm{E}+01$ & $6.19 \mathrm{E}+01$ & $1.41 \mathrm{E}+00$ & $1.83 \mathrm{E}+00$ & $7.99 \mathrm{E}-01$ & & \\
\hline ID Number & CS4G & $\overline{\mathrm{CS} 4 \mathrm{R}}$ & $\bar{R}$ F4G & RF4R & $\overline{\text { SL4G }}$ & $\overline{\text { SLAR }}$ & CP4G & $\overline{\mathrm{CP} 4 \mathrm{R}}$ & $\overline{\mathrm{CE}} 4 \mathrm{G}$ & CEAR & $\overline{\text { ZE4G }}$ & ZE4R \\
\hline Material & CS-100 & CS-100 & R-F (210) & R-F (210) & SL-644 & $\overline{S L}-644$ & IE-9]0 & $\overline{I E-910}$ & IE-911 & IE-911 & TIE-96 & TIE-96 \\
\hline Tracer & $\overline{B e}$ ICP & $\mathrm{Be} \mathrm{ICP}$ & $\mathrm{BeICP}$ & Be ICP & $\overline{\mathrm{Be} I C P}$ & $\overline{B e}$ ICP & Be ICP & $\overline{B e} I C P$ & $\overline{\mathrm{Be}} \mathrm{ICP}$ & $\overline{\mathrm{Be} I C P}$ & $\overline{\mathrm{Be} I \mathrm{ICP}}$ & $\mathrm{Be} I C P$ \\
\hline [Na], Mol. & $5.00 \mathrm{E}+00$ & $5.00 \mathrm{E}+00$ & $5.00 \mathrm{E}+00$ & $5.00 \mathrm{E}+00$ & $5.00 \mathrm{E}+00$ & $5.00 \mathrm{E}+00$ & $5.00 \mathrm{E}+00$ & $5.00 \mathrm{E}+00$ & $5.00 \mathrm{E}+00$ & $5.00 \mathrm{E}+00$ & $5.00 \mathrm{E}+00$ & $5.00 \mathrm{E}+(0) 0$ \\
\hline F Factor & $6.67 \mathrm{E}-01$ & $6.67 \mathrm{E}-01$ & $8.11 \mathrm{E}-01$ & $8.11 \mathrm{E}-01$ & $9.44 \mathrm{E}-01$ & $9.44 \mathrm{E}-01$ & $9.84 \mathrm{E}-01$ & $9 . \overline{84 \mathrm{E}-01}$ & $8.69 \mathrm{E}-01$ & $8.69 \mathrm{E}-01$ & $8.95 \mathrm{E}-01$ & $8.95 \mathrm{E}-01$ \\
\hline $\mathrm{Na} / \mathrm{Be}$ Start & $4.71 E+05$ & $4.71 E+05$ & $4.34 \mathrm{E}+05$ & $4.34 \mathrm{E}+05$ & $4.61 \mathrm{E}+05$ & $4.61 \mathrm{E}+05$ & $3.93 E+05$ & $3.93 \mathrm{E}+05$ & $4.23 \mathrm{E}+05$ & $4.23 \mathrm{E}+05$ & $4.02 \mathrm{E}+(05$ & $4.02 \mathrm{E}+05$ \\
\hline $\mathrm{Na} / \mathrm{Be}$ Final & $1.46 \mathrm{E}+06$ & $1.46 \mathrm{E}+06$ & $7.30 \mathrm{E}+05$ & $6.95 \mathrm{E}+05$ & $1.29 \mathrm{E}+06$ & $1.29 \mathrm{E}+06$ & $3.48 \mathrm{E}+05$ & $3.45 \mathrm{E}+05$ & $6.44 \mathrm{E}+05$ & $6.74 \mathrm{E}+05$ & $5.41 \mathrm{E}+05$ & $5.34 \mathrm{E}+(1) 5$ \\
\hline DF Value & $3.10 \mathrm{E}+00$ & $3.10 \mathrm{E}+00$ & $1.68 \mathrm{E}+00$ & $1.60 \mathrm{E}+00$ & $2.79 \mathrm{E}+00$ & $2.79 \mathrm{E}+00$ & $8.85 \mathrm{E}-01$ & $8.78 \mathrm{E}-01$ & $1.52 \mathrm{E}+00$ & $1.59 \mathrm{E}+00$ & $1.35 \mathrm{E}+00$ & $1.33 E+00$ \\
\hline Kd Value & $5.08 \mathrm{E}+01$ & $5.08 \mathrm{E}+01$ & $1.35 \mathrm{E}+01$ & $1.20 \mathrm{E}+01$ & $3.07 \mathrm{E}+01$ & $3.07 \mathrm{E}+01$ & $-1.92 \mathrm{E}+00$ & $-2.04 \mathrm{E}+00$ & $9.96 \mathrm{E}+00$ & $1.13 \mathrm{E}+01$ & $6.36 \mathrm{E}+00$ & $6.06 \mathrm{E}+00$ \\
\hline Density & $2.43 \mathrm{E}-01$ & $2.43 \mathrm{E}-01$ & $3.04 \mathrm{E}-01$ & $3.04 \mathrm{E}-01$ & $2.24 \mathrm{E}-01$ & $2.24 \mathrm{E}-01$ & $7.74 \mathrm{E}-01$ & $7.74 \mathrm{E}-01$ & $1.13 \mathrm{E}+00$ & $1.13 \mathrm{E}+00$ & $7.67 \mathrm{E}-01$ & $7.67 \mathrm{E}-01$ \\
\hline Lambda Value & $1.24 \mathrm{E}+01$ & $1.24 \mathrm{E}+01$ & $4.12 \mathrm{E}+00$ & $3.64 \mathrm{E}+00$ & $6.86 \mathrm{E}+00$ & $6.86 \mathrm{E}+00$ & $-1.49 \mathrm{E}+00$ & $-1.58 \mathrm{E}+00$ & $1.12 \mathrm{E}+01$ & $1.27 \mathrm{E}+01$ & $4.88 \mathrm{E}+00$ & $4.65 \mathrm{E}+00$ \\
\hline ID Number & $\mathrm{CS} 4 \mathrm{G}$ & CS4R & RF4G & RF4R & SLAG & SLAR & $\overline{\mathrm{CP}} \mathbf{\overline { G }}$ & $\overline{\mathrm{CP}} 4 \mathrm{R}$ & CE4G & CE4R & ZE4G & ZE4R \\
\hline Material & $\overline{C S}-100$ & CS-100 & R-F (210) & R-F (210) & SL-644 & SL-644 & IE-910 & IE-910 & IE-911 & IE-91] & TIE-96 & TIE-96 \\
\hline Tracer & Ca ICP & Ca ICP & Ca ICP & Ca ICP & Ca ICP & Ca ICP & Ca ICP & Ca ICP & Ca ICP & Ca ICP & Ca ICP & Ca ICP \\
\hline [Na], Mol. & $5.00 \mathrm{E}+00$ & $5.00 \mathrm{E}+00$ & $5.00 \mathrm{E}+00$ & $5.00 \mathrm{E}+00$ & $5.00 \mathrm{E}+00$ & $5.00 \mathrm{E}+00$ & $5.00 \mathrm{E}+00$ & $5.00 \mathrm{E}+00$ & $5.00 \mathrm{E}+00$ & $5.00 \mathrm{E}+00$ & $5.00 \mathrm{E}+00$ & $5.00 \mathrm{E}+00$ \\
\hline F Factor & $6.67 \mathrm{E}-01$ & $6.67 \mathrm{E}-01$ & $8.11 \mathrm{E}-01$ & $8.11 \mathrm{E}-01$ & $9.44 \mathrm{E}-01$ & $9.44 \mathrm{E}-01$ & $9.84 \mathrm{E}-01$ & $9.84 \mathrm{E}-01$ & $8.69 \mathrm{E}-01$ & $8.69 \mathrm{E}-01$ & $8.95 \mathrm{E}-01$ & $8.95 \mathrm{E}-01$ \\
\hline $\mathrm{Na} / \mathrm{Ca}$ Start & $1.60 \mathrm{E}+04$ & $1.60 \mathrm{E}+04$ & $1.60 \mathrm{E}+04$ & $1.60 \mathrm{E}+04$ & $1.60 \mathrm{E}+04$ & $1.60 \mathrm{E}+04$ & $1.60 \mathrm{E}+04$ & $1.60 \mathrm{E}+04$ & $1.60 \mathrm{E}+04$ & $1.60 \mathrm{E}+04$ & $1.60 \mathrm{E}+04$ & $1.60 \mathrm{E}+04$ \\
\hline $\mathrm{Na} / \mathrm{Ca}$ Final & $2.12 E+04$ & $2.11 \mathrm{E}+04$ & $2.41 \mathrm{E}+04$ & $1.16 \mathrm{E}+04$ & $9.72 \mathrm{E}+03$ & $9.82 \mathrm{E}+03$ & $3.40 \mathrm{E}+04$ & $3.28 \mathrm{E}+04$ & $2.24 \mathrm{E}+05$ & $2.11 \mathrm{E}+05$ & $5.31 \mathrm{E}+04$ & $6.45 \mathrm{E}+04$ \\
\hline DF Value & $1.32 \mathrm{E}+00$ & $1.32 \mathrm{E}+00$ & $1.50 \mathrm{E}+00$ & $7.25 \mathrm{E}-01$ & $6.07 \mathrm{E}-01$ & $6.13 \mathrm{E}-01$ & $2.12 E+00$ & $2.05 E+00$ & $1.40 \mathrm{E}+01$ & $1.32 \mathrm{E}+01$ & $3.32 \mathrm{E}+00$ & $4.03 \mathrm{E}+00$ \\
\hline Kd Value & $7.78 \mathrm{E}+00$ & $7.63 \mathrm{E}+00$ & $9.96 \mathrm{E}+00$ & $-5.46 \mathrm{E}+00$ & $-6.71 \mathrm{E}+00$ & $-6.61 \mathrm{E}+00$ & $1,88 \mathrm{E}+01$ & $1.76 \mathrm{E}+01$ & $2.47 \mathrm{E}+02$ & $2.32 \mathrm{E}+02$ & $4.26 \mathrm{E}+01$ & $5.58 \mathrm{E}+01$ \\
\hline Density & $2.43 \mathrm{E}-01$ & $2.43 \mathrm{E}-01$ & $3.04 \mathrm{E}-01$ & 3.04E-01 & $.2 .24 \mathrm{E}-01$ & $2.24 \mathrm{E}-01$ & $7.74 \mathrm{E}-01$ & $7.74 \mathrm{E}-01$ & $1.13 \mathrm{E}+00$ & $1.13 E+00$ & $7.67 \mathrm{E}-01$ & $7.67 \mathrm{E}-01$ \\
\hline Lambda Value & $1.89 \mathrm{E}+00$ & $1.86 \mathrm{E}+00$ & $3.03 \mathrm{E}+00$ & $-1.66 \mathrm{E}+00$ & $-1.50 \mathrm{E}+00$ & $-1.48 \mathrm{E}+00$ & $1.45 \mathrm{E}+01$ & $1.36 \mathrm{E}+01$ & $2.78 \mathrm{E}+02$ & $2.61 \mathrm{E}+02$ & $3.27 \mathrm{E}+01$ & $4.28 \mathrm{E}+01$ \\
\hline ID Number & CS4G & CS4R & RF4G & RF4R & SLAG & SLAR & CP4G & CP4R &. $\mathrm{CE} 4 \mathrm{G}$ & CE4R & ZEAG & $\overline{\text { ZE4R }}$ \\
\hline Material & CS-100 & CS-100 & R-F (210) & R-F (210) & SL-644 & SL-644 & IE-910 & IE-910 & IE-911 & IE-911 & TIE-96 & TIE-96 \\
\hline Tracer & Fe ICP & Fe ICP & Fe ICP & Fe ICP & Fe ICP & Fe ICP & Fe ICP & Fe ICP & Fe ICP & Fe ICP & Fe ICP & Fe ICP \\
\hline [Na], Mol. & $5.00 \mathrm{E}+00$ & $5.00 \mathrm{E}+00$ & $5.00 \mathrm{E}+00$ & $5.00 \mathrm{E}+00$ & $5.00 \mathrm{E}+00$ & $5.00 \mathrm{E}+00$ & $5.00 \mathrm{E}+00$ & $5.00 \mathrm{E}+00$ & $5.00 \mathrm{E}+00$ & $5.00 \mathrm{E}+00$ & $5.00 \mathrm{E}+00$ & $5.00 \mathrm{E}+00$ \\
\hline F Factor & $6.67 \mathrm{E}-01$ & $6.67 \mathrm{E}-01$ & $8.11 \mathrm{E}-01$ & $8.11 \mathrm{E}-01$ & $9.44 \mathrm{E}-01$ & $9.44 \mathrm{E}-01$ & $9.84 \mathrm{E}-01$ & $9.84 \mathrm{E}-01$ & $8.69 \mathrm{E}-01$ & $8.69 \mathrm{E}-01$ & $8.95 \mathrm{E}-01$ & $8.95 \mathrm{E}-01$ \\
\hline $\mathrm{Na} / \mathrm{Fe}$ Start & $1.48 \mathrm{E}+05$ & $1.48 \mathrm{E}+05$ & $1.48 \mathrm{E}+05$ & $1.48 \mathrm{E}+05$ & $1.48 \mathrm{E}+05$ & $1.48 \mathrm{E}+05$ & $1.48 \mathrm{E}+05$ & $1.48 E+05$ & $1.48 \mathrm{E}+05$ & $1.48 \mathrm{E}+05$ & $1.48 \mathrm{E}+05$ & $1.48 \mathrm{E}+05$ \\
\hline $\mathrm{Na} / \mathrm{Fe}$ Final & $5.48 \mathrm{E}+05$ & $6.26 \mathrm{E}+05$ & $3.84 \mathrm{E}+05$ & $3.17 \mathrm{E}+05$ & $1.74 \mathrm{E}+05$ & $4.02 \mathrm{E}+05$ & $2.04 \mathrm{E}+05$ & $2.08 \mathrm{E}+05$ & $5.09 \mathrm{E}+05$ & $6.26 \mathrm{E}+05$ & $7.39 \mathrm{E}+04$ & $7.88 \mathrm{E}+04$ \\
\hline DF Value & $3.69 \mathrm{E}+00$ & $4.22 \mathrm{E}+00$ & $2.59 \mathrm{E}+00$ & $2.14 \mathrm{E}+00$ & $1.17 \mathrm{E}+00$ & $2.71 \mathrm{E}+00$ & $1.37 \mathrm{E}+00$ & $1.40 \mathrm{E}+00$ & $3.44 \mathrm{E}+00$ & $4.22 \mathrm{E}+00$ & $4.98 \mathrm{E}-01$ & 5.31E-01 \\
\hline Kd Value & $6.52 \mathrm{E}+01$ & $7.79 \mathrm{E}+01$ & $3.16 \mathrm{E}+01$ & $2.26 \mathrm{E}+01$ & $2.95 \mathrm{E}+00$ & $2.92 \mathrm{E}+01$ & $6.26 \mathrm{E}+00$ & $6.70 \mathrm{E}+00$ & $4.65 \mathrm{E}+01$ & $6.15 E+01$ & $-9.24 \mathrm{E}+00$ & $-8.63 \mathrm{E}+00$ \\
\hline Density & $2.43 \mathrm{E}-01$ & $2.43 \mathrm{E}-01$ & $3.04 \mathrm{E}-01$ & $3.04 \mathrm{E}-01$ & $2.24 \mathrm{E}-01$ & $2.24 \mathrm{E}-01$ & $7.74 \mathrm{E}-01$ & $7.74 \mathrm{E}-01$ & $1.13 E+00$ & $1.13 \mathrm{E}+00$ & $7.67 \mathrm{E}-01$ & $7.67 \mathrm{E}-01$ \\
\hline Lambda Value & $1.59 \mathrm{E}+01$ & $1.90 \mathrm{E}+01$ & $9.61 \mathrm{E}+00$ & $6.89 \mathrm{E}+00$ & $6.60 \mathrm{E}-01$ & $6.55 \mathrm{E}+00$ & $4.84 \mathrm{E}+00$ & $5.18 \mathrm{E}+00$ & $5.23 \mathrm{E}+01$ & $6.92 \mathrm{E}+01$ & $-7.09 \mathrm{E}+00$ & $-6.62 \mathrm{E}+00$ \\
\hline
\end{tabular}


Excel 4.0 File: HOT ICP2.XLS

Page 2 of 2

5:02 PM 12/19/95

\begin{tabular}{|c|c|c|c|c|c|c|c|c|c|c|c|c|}
\hline & & & & . & & & & & & & & . \\
\hline ID Number & CS4G & $\overline{C S 4 R}$ & RF4G & RF4R & SL4G & SLAR & CP4G & CP4R & CE4G & CEAR & ZE4G & ZEAR \\
\hline Material & CS-100 & CS-100 & R-F (210) & R-F (210) & SL-644 & SL-644 & IE-910 & IE-910 & IE-911 & IE-911 & TIE-96 & TIE-96 \\
\hline Tracer & Ni ICP & Ni ICP & Ni ICP & Ni ICP & Ni ICP & Ni ICP & Ni ICP & Ni ICP & Ni ICP & - Ni ICP & $\mathrm{Ni}$ ICP & Ni ICP \\
\hline [Na], Mol. & $5.00 \mathrm{E}+00$ & $5.00 \mathrm{E}+00$ & $5.00 \mathrm{E}+00$ & $5.00 \mathrm{E}+00$ & $5.00 \mathrm{E}+00$ & $5.00 \mathrm{E}+00$ & $5.00 \mathrm{E}+00$ & $5.00 \mathrm{E}+00$ & $5.00 \mathrm{E}+00$ & $5.00 \mathrm{E}+00$ & $5.00 \mathrm{E}+00$ & $5.00 \mathrm{E}+00$ \\
\hline F Factor & $6.67 \mathrm{E}-01$ & $6.67 \mathrm{E}-01$ & $8.11 \mathrm{E}-01$ & $8.11 \mathrm{E}-01$ & $9.44 \mathrm{E}-01$ & $9.44 \mathrm{E}-01$ & $9.84 \mathrm{E}-01$ & $9.84 \mathrm{E}-01$ & $8.69 \mathrm{E}-01$ & 8.69E-01 & $8.95 \mathrm{E}-(01$ & 8.95E-()1 \\
\hline $\mathrm{Na} / \mathrm{Ni}$ Start & $6.36 \mathrm{E}+04$ & $6.36 \mathrm{E}+04$ & $5.65 \mathrm{E}+04$ & $5.65 \mathrm{E}+04$ & $6.61 \mathrm{E}+04$ & $6.61 \mathrm{E}+04$ & $4.83 \mathrm{E}+04$ & $4.83 \mathrm{E}+04$ & $4.89 \mathrm{E}+04$ & $4.89 E+04$ & $5.02 \mathrm{E}+04$ & $5.02 \mathrm{E}+04$ \\
\hline $\mathrm{Na} / \mathrm{Ni}$ Final & $1.18 \mathrm{E}+05$ & $1.18 \mathrm{E}+05$ & $7.43 \mathrm{E} \div 04$ & $6.88 \mathrm{E}+04$ & $1.58 \mathrm{E}+05$ & $1.61 E+05$ & $4.71 \mathrm{E}+04$ & $4.80 \mathrm{E}+04$ & $5.00 \mathrm{E}+04$ & $5.16 E+(14$ & $4.88 \mathrm{E}+(1) 4$ & $4.92 \mathrm{E}+04$ \\
\hline DF Value & $1.86 \mathrm{E}+00$ & $1.86 \mathrm{E}+00$ & $1.31 \mathrm{E}+00$ & $1.22 \mathrm{E}+00$ & $2.38 \mathrm{E}+00$ & $2.44 \mathrm{E}+00$ & $9.75 \mathrm{E}-01$ & $9.93 \mathrm{E}-01$ & $1.02 \mathrm{E}+00$ & $1.06 \mathrm{E}+00$ & 9.7IE-0I & $9.80 \mathrm{E}-01$ \\
\hline Kd Value & $2.09 \mathrm{E}+01$ & $2.09 \mathrm{E}+01$ & $6.22 \mathrm{E}+00$ & $4.30 \mathrm{E}+00$ & $2.37 \mathrm{E}+01$ & $2.46 \mathrm{E}+01$ & $-4.23 \mathrm{E}-01$ & $-1.19 \mathrm{E}-01$ & $4.36 \mathrm{E}-01$ & $1.06 \mathrm{E}+00$ & $-5.33 \mathrm{E}-01$ & $-3.72 \mathrm{E}-01$ \\
\hline Density & $2.43 \mathrm{E}-01$ & $2.43 \mathrm{E}-01$ & $3.04 \mathrm{E}-01$ & $3.04 \mathrm{E}-01$ & $2.24 \mathrm{E}-01$ & $2.24 \mathrm{E}-01$ & $7.74 \mathrm{E}-01$ & $7.74 \mathrm{E}-01$ & $1.13 \mathrm{E}+00$ & $1.13 \mathrm{E}+00$ & 7.67E-(01 & $7.67 \mathrm{E}-01$ \\
\hline Lambda Value & $5.08 \mathrm{E}+00$ & $5.08 \mathrm{E}+00$ & $1.89 \mathrm{E}+00$ & $1.31 \mathrm{E}+00$ & $5.30 \mathrm{E}+00$ & $5.50 \mathrm{E}+00$ & $-3.27 \mathrm{E}-01$ & $-9.21 \mathrm{E}-02$ & 4.90E-01 & $1.19 \mathrm{E}+00$ & $-4.09 \mathrm{E}-01$ & $-2.86 \mathrm{E}-01$ \\
\hline & & & & & & & & 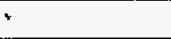 & & & & \\
\hline ID Number & CS4G & CS4R & RF4G & RF4R & $\overline{S L 4 G}$ & SL4R & CP4G & CP4R & CE4G & CE4R & ZE4G & ZE4R \\
\hline Material & CS-100 & CS-100 & $\mathrm{R}-\mathrm{F}(210)$ & R-F (210) & SL-644 & SL-644 & IE-910 & IE-910 & IE-911 & IE-9II & TIE-96 & TIE-96 \\
\hline Tracer & $\mathrm{ZnICP}$ & $\mathrm{ZnICP}$ & $\mathrm{Zn} \mathrm{ICP}$ & $\mathrm{Zn} \mathrm{ICP}$ & $\mathrm{Zn} \mathrm{ICP}$ & $\overline{\mathrm{Zn} I C P}$ & $\mathrm{Zn} \mathrm{ICP}$ & $\mathrm{Zn} \mathrm{ICP}$ & $\mathrm{Zn} \mathrm{ICP}$ & $\mathrm{ZnICP}$ & $\mathrm{Zn} \mathrm{ICP}$ & $\mathrm{Zn} \mathrm{ICP}$ \\
\hline [Na], Mol. & $5.00 \mathrm{E}+00$ & $5.00 \mathrm{E}+00$ & $5.00 \mathrm{E}+00$ & $5.00 \mathrm{E}+00$ & $5.00 \mathrm{E}+00$ & $5.00 \mathrm{E}+00$ & $5.00 \mathrm{E}+00$ & $5.00 \mathrm{E}+00$ & $5.00 \mathrm{E}+00$ & $5.00 \mathrm{E}+00$ & $5.00 \mathrm{E}+100$ & $5.00 \mathrm{E}+100$ \\
\hline F Factor & $6.67 \mathrm{E}-01$ & $6.67 \mathrm{E}-01$ & $8.11 \mathrm{E}-01$ & $8.11 \mathrm{E}-01$ & $9.44 \mathrm{E}-01$ & $9.44 \mathrm{E}-01$ & $9.84 \mathrm{E}-01$ & $9.84 \mathrm{E}-01$ & $8.69 \mathrm{E}-01$ & $8.69 \mathrm{E}-01$ & $8.95 \mathrm{E}-() 1$ & $8.95 \mathrm{E}-01$ \\
\hline $\mathrm{Na} / \mathrm{Zn}$ Start & $7.71 \mathrm{E}+04$ & $7.71 \mathrm{E}+04$ & $7.97 \mathrm{E}+04$ & $7.97 \mathrm{E}+04$ & $7.89 \mathrm{E}+04$ & $7.89 \mathrm{E}+04$ & $7.16 \mathrm{E}+04$ & $7.16 \mathrm{E}+04$ & $8.81 \mathrm{E}+04$ & $8.81 E+04$ & $9.29 \mathrm{E}+04$ & $9.29 \mathrm{E}+04$ \\
\hline $\mathrm{Na} / \mathrm{Zn}$ Final & $8.94 \mathrm{E}+04$ & $7.43 \mathrm{E}+04$ & $7.45 \mathrm{E}+04$ & $7.11 \mathrm{E}+04$ & $8.04 E+04$ & $7.12 \mathrm{E}+04$ & $7.80 \mathrm{E}+04$ & $6.67 \mathrm{E}+04$ & $1.11 \mathrm{E}+05$ & $9.40 \mathrm{E}+04$ & $1.16 \mathrm{E}+05$ & $9.24 \mathrm{E}+04$ \\
\hline DF Value & $1.16 \mathrm{E}+00$ & $9.63 \mathrm{E}-01$ & $9.35 \mathrm{E}-01$ & $8.92 \mathrm{E}-01$ & $1.02 \mathrm{E}+00$ & $9.02 \mathrm{E}-01$ & $1.09 \mathrm{E}+00$ & $9.31 \mathrm{E}-01$ & $1.26 \mathrm{E}+00$ & $1.07 \mathrm{E}+00$ & $1.25 \mathrm{E}+00$ & $9.95 \mathrm{E}-01$ \\
\hline Kd Value & $3.85 \mathrm{E}+00$ & $-9.02 \mathrm{E}-01$ & $-1.30 \mathrm{E}+00$ & $-2.14 \mathrm{E}+00$ & $3.14 \mathrm{E}-01$ & $-1.67 \mathrm{E}+00$ & $1.47 \mathrm{E}+00$ & $-1.16 \mathrm{E}+00$ & $4.87 \mathrm{E}+00$ & $1.27 \mathrm{E}+00$ & $4.62 \mathrm{E}+00$ & $-9.71 \mathrm{E}-02$ \\
\hline Density & $2.43 \mathrm{E}-01$ & $2.43 \mathrm{E}-01$ & $3.04 \mathrm{E}-01$ & $3.04 \mathrm{E}-01$ & $2.24 \mathrm{E}-01$ & $2.24 \mathrm{E}-01$ & $7.74 \mathrm{E}-01$ & $7.74 \mathrm{E}-01$ & $1.13 \mathrm{E}+00$ & $1.13 E+00$ & 7.67E-01 & 7.67E-01 \\
\hline Lambda Value & $9.37 \mathrm{E}-01$ & $-2.20 \mathrm{E}-01$ & $-3.95 \mathrm{E}-01$ & $-6.52 \mathrm{E}-01$ & $7.02 \mathrm{E}-02$ & $-3.73 \mathrm{E}-01$ & $1.14 \mathrm{E}+00$ & $-8.96 \mathrm{E}-01$ & $5.48 \mathrm{E}+00$ & $1.43 \mathrm{E}+00$ & $3.54 \mathrm{E}+00$ & $-7.45 \mathrm{E}-02$ \\
\hline ID Number & CS4G & CS4R & RF4G & RF4R & SL4G & SLAR & CP4G & CP4R & CE4G & CE4R & ZE4G & ZE4R \\
\hline Material & CS-100 & CS-100 & R-F (210) & R-F (210) & SL-644 & SL-644 & IE-910 & IE-910 & IE-911 & IE-911 & TIE-96 & TIE-96 \\
\hline Tracer & Zr ICP & $\mathrm{Zr} \mathrm{ICP}$ & $\mathrm{Zr} \mathrm{ICP}$ & $\mathrm{Zr} \mathrm{ICP}$ & $\mathrm{Zr} \mathrm{ICP}$ & Zr ICP & Zr ICP & $\mathrm{Zr} \mathrm{ICP}$ & $\mathrm{ZrICP}$ & $\mathrm{Zr} \mathrm{ICP}$ & $\mathrm{Zr} \mathrm{ICP}$ & $\mathrm{Zr} \mathrm{ICP}$ \\
\hline [Na], Mol. & $5.00 \mathrm{E}+00$ & $5.00 \mathrm{E}+00$ & $5.00 \mathrm{E}+00$ & $5.00 \mathrm{E}+00$ & $5.00 \mathrm{E}+00$ & $5.00 \mathrm{E}+00$ & $5.00 \mathrm{E}+00$ & $5.00 \mathrm{E}+00$ & $5.00 \mathrm{E}+00$ & $5.00 \mathrm{E}+00$ & $5.00 \mathrm{E}+00$ & $5.00 \mathrm{E}+00$ \\
\hline F Factor & $6.67 \mathrm{E}-01$ & $6.67 \mathrm{E}-01$ & $8.11 \mathrm{E}-01$ & $8.11 \mathrm{E}-01$ & $9.44 \mathrm{E}-01$ & $9.44 \mathrm{E}-01$ & $9.84 \mathrm{E}-01$ & $9.84 \mathrm{E}-01$ & $8.69 \mathrm{E}-01$ & $8.69 \mathrm{E}-01$ & $8.95 \mathrm{E}-01$ & $8.95 \mathrm{E}-01$ \\
\hline $\mathrm{Na} / \mathrm{Zr}$ Start & $7.97 \mathrm{E}+04$ & $7.97 \mathrm{E}+04$ & $1.35 \mathrm{E}+05$ & $1.35 \mathrm{E}+05$ & $1.71 E+05$ & $1.71 \mathrm{E}+05$ & $1.03 \mathrm{E}+05$ & $1.03 \mathrm{E}+05$ & $4.32 \mathrm{E}+04$ & $4.32 \mathrm{E}+04$ & $4.38 \mathrm{E}+05$ & $4.38 \mathrm{E}+05$ \\
\hline $\mathrm{Na} / \mathrm{Zr}$ Final & $6.26 \mathrm{E}+05$ & $5.48 \mathrm{E}+05$ & $7.18 \mathrm{E}+05$ & $8.59 \mathrm{E}+05$ & $1.10 \mathrm{E}+06$ & $1.18 \mathrm{E}+06$ & $2.76 \mathrm{E}+05$ & $2.09 \mathrm{E}+05$ & $1.62 \mathrm{E}+04$ & $1.82 \mathrm{E}+04$ & $1.62 \mathrm{E}+06$ & $1.99 \mathrm{E}+06$ \\
\hline DF Value & $7.85 \mathrm{E}+00$ & $6.87 \mathrm{E}+00$ & $5.32 \mathrm{E}+00$ & $6.36 \mathrm{E}+00$ & $6.40 \mathrm{E}+00$ & $6.92 \mathrm{E}+00$ & $2.67 \mathrm{E}+00$ & $2.02 \mathrm{E}+00$ & $3.74 \mathrm{E}-01$ & 4.21E-01 & $3.70 \mathrm{E}+00$ & $4.55 \mathrm{E}+00$ \\
\hline Kd Value & $1.66 \mathrm{E}+02$ & $1.42 \mathrm{E}+02$ & $8.56 \mathrm{E}+01$ & $1.06 \mathrm{E}+02$ & $9.23 \mathrm{E}+01$ & $1.01 \mathrm{E}+02$ & $2.79 \mathrm{E}+01$ & $1.70 \mathrm{E}+01$ & $-1.19 \mathrm{E}+01$ & $-1.10 \mathrm{E}+01$ & $4.98 \mathrm{E}+01$ & $6.53 \mathrm{E}+01$ \\
\hline Density & $2.43 \mathrm{E}-01$ & $2.43 \mathrm{E}-01$ & $3.04 \mathrm{E}-01$ & $3.04 \mathrm{E}-01$ & $2.24 \mathrm{E}-01$ & $2.24 \mathrm{E}-01$ & $7.74 \mathrm{E}-01$ & $7.74 \mathrm{E}-01$ & $1.13 \mathrm{E}+00$ & $1.13 \mathrm{E}+00$ & $7.67 \mathrm{E}-01$ & $7.67 \mathrm{E}-01$ \\
\hline Lambda Value & $4.03 \mathrm{E}+01$ & $3.45 \mathrm{E}+01$ & $2.61 \mathrm{E}+01$ & $3.24 \mathrm{E}+01$ & $2.07 \mathrm{E}+01$ & $2.26 \mathrm{E}+01$ & $2.16 \mathrm{E}+01$ & $1.32 \mathrm{E}+01$ & $-1.34 \mathrm{E}+01$ & $-1.24 \mathrm{E}+01$ & $3.82 \mathrm{E}+01$ & $5.01 \mathrm{E}+01$ \\
\hline
\end{tabular}




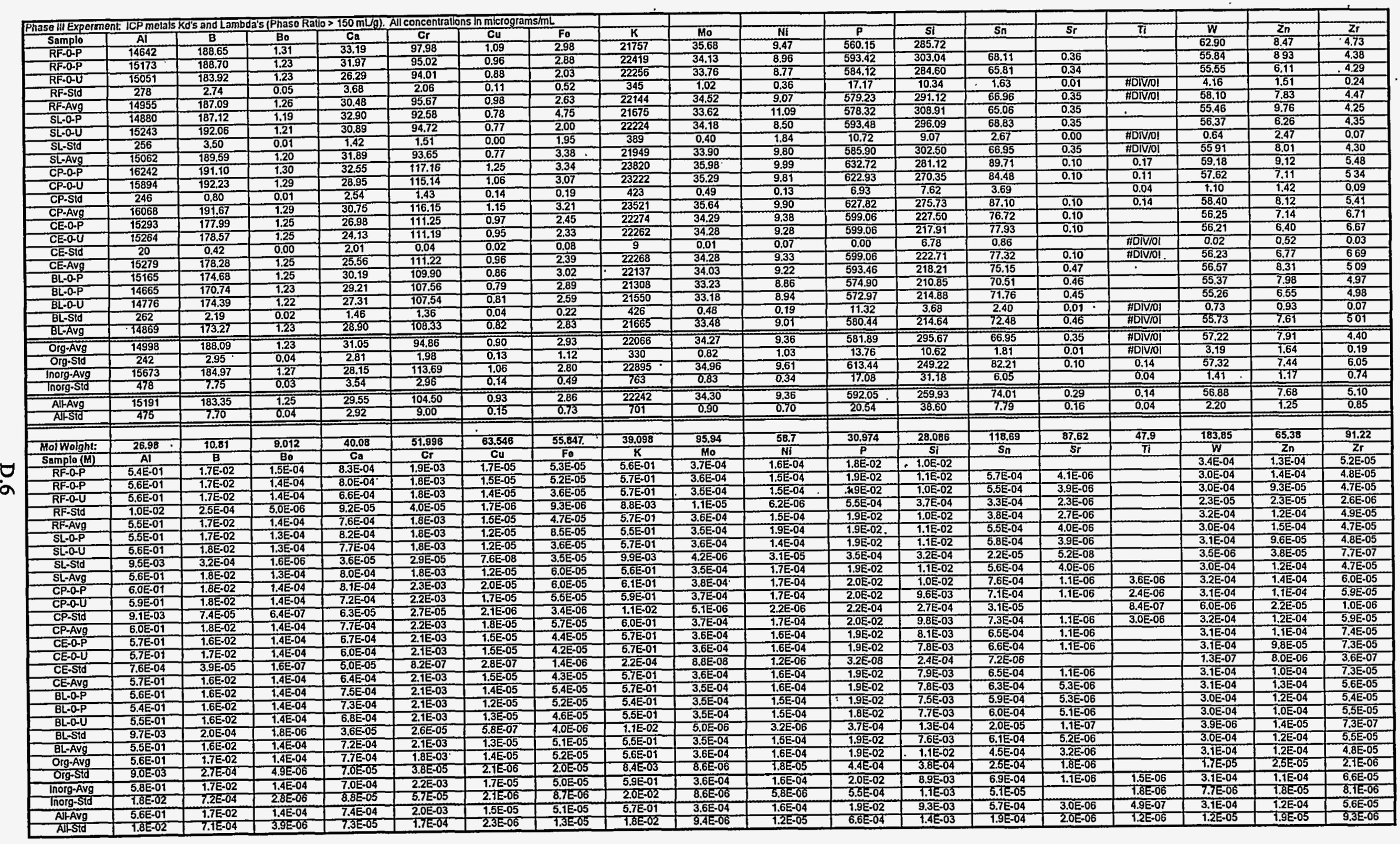




\begin{tabular}{|c|c|c|c|c|c|c|c|c|c|}
\hline \multicolumn{10}{|c|}{ Method 3 High Phase Ratio Experiment: ICP metals Kd's and Lambda's (Phase Ratio $>1000 \mathrm{~g} / . \mathrm{mL}$ ) } \\
\hline & & & & & & & & & \\
\hline ID Number & SL4P & SL4U & RF4P-1 & RF4P-2 & $\mathrm{RF} 4 \mathrm{U}$ & CP4P & $\mathrm{CP} 4 \mathrm{U}$ & CE4P & $\overline{\text { CE4U }}$ \\
\hline Material & SL-644 & SL-644 & R-F (210) & R-F (210) & $\mathrm{R}-\mathrm{F}(210)$ & IE-910 & IE-910 & IE-911 & IE-911 \\
\hline Tracer & Cr ICP & Cr ICP & Cr ICP & $\mathrm{Cr} \mathrm{ICP}$ & $\mathrm{Cr}$ ICP & Cr ICP & Cr ICP & Cr ICP & $\mathrm{Cr}$ ICP \\
\hline [Na], Mol. & $5.00 \mathrm{E}+00$ & $5.00 \mathrm{E}+00$ & $5.00 \mathrm{E}+00$ & $5.00 \mathrm{E}+00$ & $5.00 \mathrm{E}+00$ & $5.00 \mathrm{E}+00$ & $5.00 \mathrm{E}+00$ & $5.00 \mathrm{E}+00$ & $5.00 \mathrm{E}+00$ \\
\hline F Factor & $8.11 \mathrm{E}: 01$ & $8.11 \mathrm{E}-01$ & $6.67 \mathrm{E}-01$ & $6.67 \mathrm{E}-01$ & $6.67 \mathrm{E}-01$ & $9.84 \mathrm{E}-01$ & $9.84 \mathrm{E}-01$ & $8.69 \mathrm{E}-01$ & $8.69 \mathrm{E}-01$ \\
\hline $\mathrm{Na} / \mathrm{Cr}$ Start & $2.40 \mathrm{E}+03$ & $2.40 \mathrm{E}+03$ & $2.40 \mathrm{E}+03$ & $2.40 \mathrm{E}+03$ & $2.40 \mathrm{E}+03$ & $2.40 \mathrm{E}+03$ & $2.40 \mathrm{E}+03$ & $2.40 \mathrm{E}+03$ & $2.40 \mathrm{E}+03$ \\
\hline $\mathrm{Na} / \mathrm{Cr}$ Final & $2.81 \mathrm{E}+03$ & $2.74 \mathrm{E}+03$ & $2.65 \mathrm{E}+03$ & $2.74 \mathrm{E}+03$ & $2.77 \mathrm{E}+03$ & $2.22 \mathrm{E}+03$ & $2.26 \mathrm{E}+03$ & $2.34 \mathrm{E}+03$ & $2.34 \mathrm{E}+03$ \\
\hline DF Value & $1.17 \mathrm{E}+00$ & $1.14 \mathrm{E}+00$ & $1.11 \mathrm{E}+00$ & $1.14 \mathrm{E}+00$ & $1.15 \mathrm{E}+00$ & $9.25 \mathrm{E}-(01$ & $9.41 \mathrm{E}-01$ & $9.74 \mathrm{E}-01$ & $9.74 \mathrm{E}-01$ \\
\hline Kd Value & $8.16 \mathrm{E}+01$ & $6.89 \mathrm{E}+01$ & $6.11 \mathrm{E}+01$ & $8.10 \mathrm{E}+01$ & $8.80 \mathrm{E}+01$ & $-5.68 \mathrm{E}+01$ & $-4.45 \mathrm{E}+01$ & $-2.22 \mathrm{E}+01$ & $-2.17 \mathrm{E}+01$ \\
\hline Density & $2.24 \mathrm{E}-01$ & $2.24 \mathrm{E}-01$ & $2.43 \mathrm{E}-01$ & $2.43 \mathrm{E}-01$ & $2.43 \mathrm{E}-01$ & $7.74 \mathrm{E}-01$ & $7.74 \mathrm{E}-01$ & $1.13 \mathrm{E}+00$ & $1.13 \mathrm{E}+00$ \\
\hline Lambda Value & $1.83 \mathrm{E}+01$ & $1.54 \mathrm{E}+01$ & $1.49 \mathrm{E}+01$ & $1.97 \mathrm{E}+01$ & $2.14 \mathrm{E}+01$ & $-4.39 \mathrm{E}+01$ & $-3.45 \mathrm{E}+01$ & $-2.49 \mathrm{E}+01$ & $-2.44 \mathrm{E}+01$ \\
\hline ID Number & RF4P-1 & RF4P-2. & $\overline{\text { RF4U }}$ & SL4P & SL4U & CP4P & CP4U & CE4P & CE4U \\
\hline Material & R-F (210) & R-F (210) & $\mathrm{R}-\mathrm{F}(210)$ & SL-644 & SL-644 & SL-644 & SL-644 & IE-911 & IE-911 \\
\hline Tracer & Be ICP & Be ICP & Be ICP & Be ICP & Be ICP & Be ICP & Be ICP & Be ICP & Be ICP \\
\hline [Na], Mol. & $5.00 \mathrm{E}+00$ & $5.00 \mathrm{E}+00$ & $5.00 \mathrm{E}+00$ & $5.00 \mathrm{E}+00$ & $5.00 \mathrm{E}+00$ & $5.00 \mathrm{E}+00$ & $5.00 \mathrm{E}+00$ & $5.00 \mathrm{E}+00$ & $5.00 \mathrm{E}+00$ \\
\hline F Factor & $8.11 \mathrm{E}-01$ & $8.11 \mathrm{E}-01$ & $8.11 \mathrm{E}-01$ & $9.44 \mathrm{E}-01$ & $9.44 \mathrm{E}-01$ & $9.84 \mathrm{E}-01$ & $9.84 \mathrm{E}-01$ & $8.69 \mathrm{E}-01$ & $8.69 \mathrm{E}-01$ \\
\hline $\mathrm{Na} / \mathrm{Be}$ Start & $3.55 \mathrm{E}+05$ & $3.55 \mathrm{E}+05$ & $3.55 \mathrm{E}+05$ & $3.55 \mathrm{E}+05$ & $3.55 \mathrm{E}+05$ & $3.55 \mathrm{E}+05$ & $3.55 \mathrm{E}+05$ & $3.55 \mathrm{E}+05$ & $3.55 \mathrm{E}+05$ \\
\hline $\mathrm{Na} / \mathrm{Be}$ Final & $3.35 \mathrm{E}+05$ & $3.55 \mathrm{E}+05$ & $3.57 \mathrm{E}+05$ & $3.68 \mathrm{E}+05$ & $3.62 \mathrm{E}+05$ & $3.38 \mathrm{E}+05$ & $3.40 \mathrm{E}+05$ & $3.51 \mathrm{E}+05$ & $3.51 \mathrm{E}+05$ \\
\hline DF Value & $9.43 \mathrm{E}-01$ & $1.00 \overline{\mathrm{E}}+00$ & $1.01 \mathrm{E}+00$ & $1.04 \mathrm{E}+00$ & $1.02 \mathrm{E}+00$ & $9.52 \mathrm{E}-01$ & $9.58 \mathrm{E}-01$ & $9.87 \mathrm{E}-01$ & $9.89 \mathrm{E}-01$ \\
\hline Kd Value & $-2.70 \mathrm{E}+01$ & $-2.31 \mathrm{E}-01$ & $2.79 \mathrm{E}+00$ & $1.48 \mathrm{E}+01$ & $7.82 \mathrm{E}+00$ & $-3.69 \mathrm{E}+01$ & $-3.23 \mathrm{E}+01$ & $-1.10 \mathrm{E}+01$ & $-9.62 \mathrm{E}+00$ \\
\hline Density & $3.04 \mathrm{E}-01$ & $3.04 \mathrm{E}-01$ & $3.04 \mathrm{E}-01$ & $2.24 \mathrm{E}-01$ & $2.24 \mathrm{E}-01$ & $7.74 \mathrm{E}-01$ & $7.74 \mathrm{E}-01$ & $1.13 E+00$ & $1.13 E+00$ \\
\hline Lambda Value & $-8.23 \mathrm{E}+00$ & $-7.04 \mathrm{E}-02$ & $8.50 \mathrm{E}-01$ & $3.31 \mathrm{E}+00$ & $1.75 \mathrm{E}+00$ & $-2.86 \mathrm{E}+01$ & $-2.50 \mathrm{E}+01$ & $-1.23 \mathrm{E}+01$ & $-1.08 \mathrm{E}+01$ \\
\hline ID Number & RF4P-1 & RF4P-2 & RF4U & SL4P & SL4U & CP4P & $\overline{\mathrm{CP} 4 \mathrm{U}}$ & CE4P & CE4U \\
\hline Material & R-F (210) & R-F (210) & R-F (210) & SL-644 & SL-644 & SL-644 & SL-644 & $\mathrm{IE}-911$ & IE-911 \\
\hline Tracer & $\mathrm{Ca}$ ICP & $\mathrm{Ca}$ ICP & Ca ICP & $\mathrm{Ca}$ ICP & $\overline{\mathrm{Ca} I C P}$ & Ca ICP & $\mathrm{Ca}$ ICP & Ca ICP & $\mathrm{Ca}$ ICP \\
\hline [Na], Mol. & $5.00 \mathrm{E}+00$ & $5.00 \mathrm{E}+00$ & $5.00 \mathrm{E}+00$ & $5.00 \mathrm{E}+00$ & $5.00 \mathrm{E}+00$ & $5.00 \mathrm{E}+00$ & $5.00 \mathrm{E}+00$ & $5.00 \mathrm{E}+00$ & $5.00 \mathrm{E}+00$ \\
\hline F Factor & $8.11 \mathrm{E}-01$ & $8.11 \mathrm{E}-01$ & $8.11 \mathrm{E}-01$ & $9.44 \mathrm{E}-01$ & $9.44 \mathrm{E}-01$ & $9.84 \mathrm{E}-01$ & 9.84E-01 & $8.69 \mathrm{E}-01$ & $8.69 \mathrm{E}-01$ \\
\hline $\mathrm{Na} / \mathrm{Ca}$ Start & $1.52 \mathrm{E}+04$ & $1.52 \mathrm{E}+04$ & $1.52 \mathrm{E}+04$ & $1.52 \mathrm{E}+04$ & $1.52 \mathrm{E}+04$ & $1.52 \mathrm{E}+04$ & $1.52 \mathrm{E}+04$ & $1.52 \mathrm{E}+04$ & $1.52 \mathrm{E}+04$ \\
\hline $\mathrm{Na} / \mathrm{Ca}$ Final & $1.32 \mathrm{E}+04$ & $1.37 \mathrm{E}+04$ & $1.67 \mathrm{E}+04$ & $1.33 \mathrm{E}+04$ & $1.42 \mathrm{E}+04$ & $1.35 \mathrm{E}+04$ & $1.51 \mathrm{E}+04$ & $1.62 \mathrm{E}+04$ & $1.82 \mathrm{E}+04$ \\
\hline DF Value & $8.71 \mathrm{E}-01$ & $9.04 \mathrm{E}-01$ & $1.10 \mathrm{E}+00$ & $8.78 \mathrm{E}-01$ & $9.36 \mathrm{E}-01$ & $8.88 \mathrm{E}-01$ & $9.98 \mathrm{E}-01$ & $1.07 \mathrm{E}+00$ & $1.20 \mathrm{E}+00$ \\
\hline Kd Value & $-6.14 \mathrm{E}+01$ & $-4.56 \mathrm{E}+01$ & $4.73 \mathrm{E}+01$ & $-5.00 \mathrm{E}+01$ & $-2.65 \mathrm{E}+01$ & $-8.62 \mathrm{E}+01$ & $-1.28 \mathrm{E}+00$ & $6.02 \mathrm{E}+01$ & $1.67 \mathrm{E}+02$ \\
\hline Density & $3.04 \mathrm{E}-01$ & $3.04 \mathrm{E}-01$ & $3.04 \mathrm{E}-01$ & $2.24 \mathrm{E}-01$ & $2.24 \mathrm{E}-01$ & $7.74 \mathrm{E}-01$ & $7.74 \mathrm{E}-01$ & $1.13 \mathrm{E}+00$ & $1.13 E+00$ \\
\hline Lambda Value & $-1.87 \mathrm{E}+01$ & $-1.39 \mathrm{E}+01$ & $1.44 \mathrm{E}+01$ & $-1.12 \mathrm{E}+01$ & $-5.92 \mathrm{E}+00$ & $-6.67 \mathrm{E}+01$ & $-9.93 \mathrm{E}-01$ & $6.77 \mathrm{E}+01$ & $1.88 \mathrm{E}+02$ \\
\hline
\end{tabular}




\begin{tabular}{|c|c|c|c|c|c|c|c|c|c|}
\hline ID Number & RF4P-1. & RF4P-2 & RF4U & SL4P & SL4U & $\overline{\mathrm{CP}} 4 \mathrm{P}$ & $\mathrm{CP} 4 \mathrm{U}$ & CE4P & CE4U \\
\hline Material & R-F (210) & $\mathrm{R}-\mathrm{F}(210)$ & $\mathrm{R}-\mathrm{F}(210)$ & SL-644 & SL-644 & SL-644 & SL-644 & IE-911 & IE-911 \\
\hline Tracer & $\mathrm{Cu} \mathrm{ICP}$ & $\mathrm{Cu}$ ICP & $\mathrm{Cu}$ ICP & $\mathrm{Cu}$ ICP & $\mathrm{Cu}$ ICP & $\mathrm{Cu}$ ICP & $\mathrm{Cu}$ ICP & $\mathrm{Cu}$ ICP & $\mathrm{Cu}$ ICP \\
\hline [Na], Mol. & $5.00 \mathrm{E}+00$ & $5.00 \mathrm{E}+00$ & $5.00 \overline{\mathrm{E}}+00$ & $5.00 \mathrm{E}+00$ & $5.00 \mathrm{E}+00$ & $5.00 \mathrm{E}+00$ & $5.00 \overline{\mathrm{E}}+00$ & $5.00 \mathrm{E}+00$ & $5.00 \mathrm{E}+(00)$ \\
\hline F Factor & $8.11 \mathrm{E}-01$ & $8.11 \mathrm{E}-01$ & $8.11 \mathrm{E}-01$ & $9.44 \mathrm{E}-01$ & $9 . \overline{4 \mathrm{E}-01}$ & $9.84 \mathrm{E}-01$ & $9.84 \mathrm{E}-01$ & $8.69 \mathrm{E}-01$ & $8.69 \mathrm{E}-01$ \\
\hline $\mathrm{Na} / \mathrm{Cu}$ Start & $5.35 \mathrm{E}+05$ & $5.35 \mathrm{E}+05$ & $5.35 \mathrm{E}+05$ & $5.35 \mathrm{E}+05$ & $5.35 \mathrm{E}+05$ & $5.35 \mathrm{E}+05$ & $5.35 \mathrm{E}+05$ & $5.35 \mathrm{E}+05$ & $5.35 \mathrm{E}+05$ \\
\hline $\mathrm{Na} / \mathrm{Cu}$ Final & $4.01 \mathrm{E}+05$ & $4.56 \mathrm{E}+05$ & $4.97 \overline{\mathrm{E}+05}$ & $5.63 \mathrm{E}+05$ & $5.68 \mathrm{E}+05$ & $3.51 \mathrm{E}+05$ & $4.14 \mathrm{E}+05$ & $4.50 \mathrm{E}+05$ & $4.62 E+(05$ \\
\hline DF Value & $7.50 \mathrm{E}-01$ & $8.52 \mathrm{E}-01$ & $9.30 \mathrm{E}-01$ & $1.05 \mathrm{E}+00$ & $1.06 \mathrm{E}+00$ & $6.56 \mathrm{E}-01$ & $7.75 \mathrm{E}-01$ & $8.42 \mathrm{E}-01$ & $8.64 \mathrm{E}-01$ \\
\hline Kd Value & $-1.19 \mathrm{E}+02$ & $-7.02 \mathrm{E}+01$ & $-3.34 \mathrm{E}+01$ & $2.21 \mathrm{E}+01$ & $2.60 \mathrm{E}+01$ & $-2.65 \mathrm{E}+02$ & $-1.73 \mathrm{E}+02$ & $-1.34 \mathrm{E}+02$ & $-1.15 \mathrm{E}+(02$ \\
\hline Density & $3.04 \mathrm{E}-01$ & $3.04 \mathrm{E}-01$ & $3.04 \mathrm{E}-01$ & $2.24 \mathrm{E}-01$ & $2.24 \mathrm{E}-01$ & $7.74 \mathrm{E}-01$ & $7.74 \mathrm{E}-01$ & $1.13 \mathrm{E}+(00$ & $1.13 E+00$ \\
\hline Lambda Value & $-3.61 E+01$ & $-2.14 E+01$ & $-1.02 \mathrm{E}+01$ & $4.95 \mathrm{E}+00$ & $5.81 \mathrm{E}+00$ & $-2.05 \mathrm{E}+02$ & $-1.34 \mathrm{E}+02$ & $-1.50 \mathrm{E}+02$ & $-1.29 \mathrm{E}+02$ \\
\hline & & & & & & & (7) & & \\
\hline ID Number & RF4P-1 & $\mathrm{RF} 4 \mathrm{P}-2$ & RF4U & SL4P & SL4U & CP4P & CP4U & CE4P & CE4U \\
\hline Material & $\mathrm{R}-\mathrm{F}(210)$ & $\mathrm{R}-\mathrm{F}(210)$ & R-F (210) & SL-644 & SL-644 & SL-644 & SL-644 & IE-911 & IE-911 \\
\hline Tracer & Sr ICP & Sr ICP & Sr ICP & Sr ICP & Sr ICPP & Sr ICP & Sr ICP & Sr ICP & Sr ICP \\
\hline [Na], Mol. & $5.00 \mathrm{E}+00$ & $5.00 \mathrm{E}+00$ & $5.00 \overline{\mathrm{E}}+00$ & $5.00 \mathrm{E}+00$ & $5.00 \mathrm{E}+00$ & $5.00 \mathrm{E}+00$ & $5.00 \mathrm{E}+00$ & $5.00 \mathrm{E}+00$ & $5.00 \mathrm{E}+00$ \\
\hline F. Factor & $8.11 \mathrm{E}-01$ & $8.11 \mathrm{E}-01$ & $8.11 \mathrm{E}-01$ & $9.44 \mathrm{E}-01$ & $9.44 \mathrm{E}-01$ & $9.84 \mathrm{E}-01$ & $9.84 \mathrm{E}-01$ & $8.69 \mathrm{E}-01$ & $8.69 \mathrm{E}-01$ \\
\hline $\mathrm{Na} / \mathrm{Sr}$ Start & $9.52 \mathrm{E}+05$ & $9.52 \mathrm{E}+05$ & $9.52 \mathrm{E}+05$ & $9.52 \mathrm{E}+05$ & $9.52 \mathrm{E}+05$ & $9.52 \mathrm{E}+05$ & $9.52 \mathrm{E}+05$ & $9.52 \mathrm{E}+05$ & $9.52 E+05$ \\
\hline $\mathrm{Na} / \mathrm{Sr}$ Final & \#DIV/0! & $1.22 \mathrm{E}+06$ & $1.29 \overline{\mathrm{E}+06}$ & $1.24 \mathrm{E}+06$ & $1.27 \mathrm{E}+06$ & $4.38 \mathrm{E}+06$ & $4.38 \mathrm{E}+06$ & $4.38 \mathrm{E}+06$ & $4.38 \mathrm{E}+06$ \\
\hline DF Value & \#DIV/0! & $1.28 \mathrm{E}+00$ & $1.36 \mathrm{E}+00$ & $1.31 \mathrm{E}+00$ & $1.33 \mathrm{E}+00$ & $4.60 \mathrm{E}+00$ & $4.60 \mathrm{E}+00$ & $4.60 \mathrm{E}+00$ & $4.60 \mathrm{E}+00$ \\
\hline Kd Value & \#DIV/0! & $1.33 \mathrm{E}+02$ & $1.69 \mathrm{E}+02$ & $1.26 \mathrm{E}+02$ & $1.36 \mathrm{E}+02$ & $2.77 \mathrm{E}+03$ & $2.77 \mathrm{E}+03$ & $3.04 \mathrm{E}+03$ & $3.04 \mathrm{E}+03$ \\
\hline Density & 3.04E-01 & $3.04 \mathrm{E}-01$ & $3.04 \mathrm{E}-01$ & $2.24 \mathrm{E}-01$ & $2.24 \mathrm{E}-01$ & $7.74 \mathrm{E}-01$ & $7.74 \mathrm{E}-01$ & $1.13 E+00$ & $1.13 E+00$ \\
\hline Lambda Value & \#DIV/0! & $4.06 \mathrm{E}+01$ & $5.14 \mathrm{E}+01$ & $2.83 \mathrm{E}+01$ & $3.05 \mathrm{E}+01$ & $2.14 \mathrm{E}+03$ & $2.14 E+03$ & $3.43 \mathrm{E}+03$ & $3.43 \mathrm{E}+03$ \\
\hline ID Number & RF4P-1 & RF4P-2 & RF4U & $\overline{\text { SL4P }}$ & SL4U & CP4P & CP4U & CE4P & $\overline{\mathrm{CE} 4 \mathrm{U}}$ \\
\hline Material & R-F (210) & R-F (210) & R-F (210) & SL-644 & SL-644 & SL-644 & SL-644 & IE-911 & IE-911 \\
\hline Tracer & $\mathrm{ZrICP}$ & $\mathrm{Zr} \mathrm{ICP}$ & Zr ICP & $\mathrm{Zr} \mathrm{ICP}$ & Zr ICP & Zr ICP & Zr ICP & Zr ICP & $\mathrm{Zr}$ ICP \\
\hline [Na], Mol. & $5.00 \mathrm{E}+00$ & $5.00 \mathrm{E}+00$ & $5.00 \mathrm{E}+00$ & $5.00 \mathrm{E}+00$ & $5.00 \mathrm{E}+00$ & $5.00 \mathrm{E}+00$ & $5.00 \mathrm{E}+00$ & $5.00 \mathrm{E}+00$ & $5.00 \mathrm{E}+00$ \\
\hline F Factor & $8.11 \mathrm{E}-01$ & $8.11 \mathrm{E}-01$ & $8.11 \mathrm{E}-01$ & $9.44 \mathrm{E}-01$ & $9.44 \mathrm{E}-01$ & $9.84 \mathrm{E}-01$ & $9.84 E-01$ & $8.69 \mathrm{E}-01$ & $8.69 \mathrm{E}-01$ \\
\hline $\mathrm{Na} / \mathrm{Zr}$ Start & $8.74 \mathrm{E}+04$ & $8.74 \mathrm{E}+04$ & $8.74 \mathrm{E}+04$ & $8.74 \mathrm{E}+04$ & $8.74 \mathrm{E}+04$ & $8.74 \mathrm{E}+04$ & $8.74 \mathrm{E}+04$ & $8.74 \mathrm{E}+04$ & $8.74 \mathrm{E}+04$ \\
\hline $\mathrm{Na} / \mathrm{Zr}$ Final & $9.26 \mathrm{E}+04$ & $1.00 \mathrm{E}+05$ & $1.02 \mathrm{E}+05$ & $1.03 \mathrm{E}+05$ & $1.01 \mathrm{E}+05$ & $8.00 \mathrm{E}+04$ & $8.20 \mathrm{E}+04$ & $6.53 \mathrm{E}+04$ & $6.57 \mathrm{E}+04$ \\
\hline DF Value & $1.06 \mathrm{E}+00$ & $1.14 \mathrm{E}+00$ & $1.17 \mathrm{E}+00$ & $1.18 \mathrm{E}+00$ & $1.15 \mathrm{E}+00$ & $9.15 \mathrm{E}-01$ & $9.37 \mathrm{E}-01$ & $7.46 \mathrm{E}-01$ & $7.52 \mathrm{E}-01$ \\
\hline Kd Value & $2.79 \mathrm{E}+01$ & $6.84 \mathrm{E}+01$ & $8.03 \mathrm{E}+01$ & $7.31 \mathrm{E}+01$ & $6.21 \mathrm{E}+01$ & $-6.57 \mathrm{E}+01$ & $-4.82 \mathrm{E}+01$ & $-2.14 \mathrm{E}+02$ & $-2.10 \mathrm{E}+02$ \\
\hline Density & $3.04 \mathrm{E}-01$ & $3.04 \mathrm{E}-01$ & $3.04 \mathrm{E}-01$ & $2.24 \mathrm{E}-01$ & $2.24 \mathrm{E}-01$ & $7.74 \mathrm{E}-01$ & $7.74 \mathrm{E}-01$ & $1.13 \mathrm{E}+00$ & $1.13 E+00$ \\
\hline Lambda Value & $8.48 \mathrm{E}+00$ & $2.08 \mathrm{E}+01$ & $2.44 \mathrm{E}+01$ & $1.64 \mathrm{E}+01$ & $1.39 \mathrm{E}+01$ & $-5.09 \mathrm{E}+01$ & $-3.73 \mathrm{E}+01$ & $-2.41 \mathrm{E}+02$ & $-2.36 \mathrm{E}+02$ \\
\hline
\end{tabular}




\section{Distribution}

No, of

Copies

\section{OFFSITE}

2 DOE/Office of Scientific and Technical Information

G. Allen

Department 6607/MS 0756

Sandia National Laboratories

P.O. Box 5800

Albuquerque, NM 87185-0756

D. H. Bandy

U.S. Department of Energy

P.O. Box 5400

Albuquerque, NM 87115

J. E. Baublitz, EM-40

DOE/Office of Environmental Restoration

Forrestal Building

U.S. Department of Energy

1000 Independence Ave. SW .

Washington, DC 20585

\section{J. P. Bibler}

Westinghouse Savannah River Co.

Building $773 \mathrm{~A}$

Aiken, SC 29802

2 W. W. Bixby, EM-60

DOE/Office of the Deputy Assistant Secretary

Facility

Transition and Management

U.S. Department of Energy

1000 Independence Ave. SW

Washington, DC 20585
No. of

Copies

W. Bliss

Environmental Management Div.

Reynolds Electrical and Engineering Co., Inc.

2501 Wyandotte

P.O. Box 98521

Las Vegas, NV 89193-8521

N. E. Brown

Sandia National Laboratories

P.O. Box 5800

Albuquerque, NM 87185-0756 .

R. L. Bruening

505 East 1860 South

IBC Advanced Technologies, Inc.

American Fork, UT 84603

J. Corones

AMES Laboratory

329 Wilhelm Hall

Iowa State University

Ames, IA 50011

R. Craig

HAZWRAP

P.O. Box 2003, MS 7606

Oak Ridge, TN 37831-7606

7 DOE/Office of Technology Development

Trevion II Building

12800 Middlebrook Road

Germantown, MD 20874

ATTN: G. G. Boyd

EM-50

T. B. Fryberger

S. T. Lien

EM-53

R. T. Parker

EM-53

P. J. Ritzcovan

EM-52

W. C. Schutte

EM-542

S. M. Wolfe

EM-532 
No. of

Copies

5 DOE/Office of Waste Management

Trevion II Building

12800 Middlebrook Road

Germantown, MD 20874

ATTN: J. O. Boda

EM-32

J. A. Coleman

S. P. Cowan

S. L. Domotor

H. F. Walter

N. Egan

Program Development Division

MSE Inc.

P.O. Box 3767

Butte, MT 59702

D. Emilia

Strategic Planning Dept.

Chem-Nuclear Geotech

P.O. Box 1400

2597B-3/4 Road (81503)

Grand Junction, CO 81502-2567

B. Erdal

Los Alamos National Laboratory MS D446

Los Alamos, NM 87545

2 J. J. Fiore, EM-42

DOE/Office of Environmental Restoration

Trevion II Building

12800 Middlebrook Road

Germantown, MD 20874

C. W. Frank, EM-50

DOE/Office of Technology Development

Forrestal Building

U.S. Department of Energy

1000 Independence Ave. SW

Washington, D.C. 20585

E. Franz

Brookhaven National Laboratory

Building 830

Upton, NY 11973
No. of

Copies

J. E. Helt

Office of Waste Management Programs

9700 South Cass Avenue

Argonne, IL 60439-4837

R. Jacobson

Desert Research Institute

P.O. box 19040

Las Vegas, NV 89132

T. M. Kafka

3M Center

Bldg. 209-1W-24

St. Paul, MN 55144-1000

K. Kibbe

Martin Marietta Energy Systems

P.O. Box 2003

Bldg. K-1011, MS 7172

Highway 58

Oak Ridge, TN 37831-7172

K. Kostelnik

EG\&G Idaho, Inc., MS 3930

P.O. Box 1625

200 South Woodruff

Idaho Falls, ID 83415-3970

J. E. Lytle, EM-30

DOE/Office of Waste Operations

Forrestal Building

U.S. Department of Energy

1000 Independent Ave. SW

Washington, D.C. 20585

J. F. McGlynn

SAIC

555 Quince Orchard Road, Suite 500

Gaithersburg, MD 20878

K. McWilliam

U.S. Department of Energy

Nevada Operations Office

P.O. Box 98518

Las Vegas, NV 89109

Distr.2 
No. of

Copies

J. Moore

U.S. Department of Energy

Oak Ridge Operations Office

P.O. Box E

Oak Ridge, TN 37831

J. Nelson

Sandia National Laboratories

P.O. Box 5800, Division 6621

Albuquerque, NM 87185-5800

K. Nuhfer

FERMCO

P.O. Box 398704

Cincinnati, OH 45239-8704

9 Oak Ridge National Laboratory

P.O. Box 2008

Oak Ridge, TN 378731-6223

ATTN: J. B. Berry

J. L. Collins

MS-6044

MS-6221

MS-6223

B. Z. Egan

R. D. Hunt

D. Lee

A. P. Malinauskas

C. P. McGinnis

J. F. Walker

J. S. Watșion

D. Olona

U.S. Department of Energy

Albuquerque Operations office

P.O. Box 5400

Albuquerque, NM 87115

J. L. Peterson

EG\&G Rocky Flats, Inc.

P.O. Box 464, Building T130B

Golden, CO 80402-0464

P. J. Pettit

P.O. Box 538704

Mailstop 81-2

Cincinnati, OH 45253-8704
No. of .

Copies

L. Rogers

EG\&G Energy Measurements, Inc.

P.O. Box 1912, MS RSL-11

Las Vegas, NV 89125

R. Scott

U.S. Department of Energy

San Francisco Field Office

1333 Broadway

Oakland, CA 94612

G. Staats

U.S. Department of Energy

Pittsburgh Energy Technology Center

P.O. Box 10940

Pittsburgh, PA 15236-0940

J. L. Steele

Savannah River Site

SRL, 773 A, A208

Aiken, SC 29802

S. L. Stein

Battelle Seattle Research Center

4000 NE 41st Street

Seattle, WA 98105

K. Stevenson

U.S. Department of Energy

376 Hudson Street

New York, NY 10014-3621

J. L. Swanson

1318 Cottonwood Drive

Richland, WA 99352

J. Sweeney

U.S. Department of Energy

Oak Ridge Operations Office

P.O. Box E

Oak Ridge, TN 37831 
No. of

Copies

I. R. Tasker

Waste Policy Institute.

Quince Diamond Executive Center

555 Quince Orchard Road

Gaithersburg, MD 20878-1437

M. C. Thompson

Savannah River Technology Center

P.O. Box 616

Aiken, SC 29802

T. A. Todd

Lockheed Idaho Technology Company

P.O. Box 1625, MS 5213

Idaho Falls, ID 83415

C. Tsang

Earth Sciences Division

Bldg. 50E

Lawrence Berkeley Laboratory

Berkeley, CA 94720

S. Turner

BNFL

2261 Stevens Drive

Richland, WA 99352

S. Webster

U.S. Department of Energy

Chicago Field Office

9800 South Cass Avenue

Argonne, II 60439-4837

T. Williams

U.S. Department of Energy

Idaho Operations Office

785 DOE Place

Idaho Falls, ID 83402

J. Wright

U.S. Department of Energy

Savannah River Operations Office

RFD \#1, Bldg. 703A, Rm. E208 North

P.O. Box A

Aiken, SC 29802
No. of

Copies

J. Yow

Lawrence Livermore National Laboratory 7000 East Avenue

P.O. Box 808

Livermore, CA 94550

C. Zeh

Morgantown Energy Technology Center

3610 Collins Ferry Road

Morgantown, WV 26507-0880

\section{ONSITE}

5 DOE Richland Operations Office

P. E. Lamont

S7-53

C. S. Louie

S7-53

B. M. Mauss

K8-50

D. E. Trader

K8-50

L. S. Walder

S7-53

\section{MACTEC}

D. J. Swanberg

K8-50

14 Westinghouse Hanford Company

J. N. Appel

G3-21

S. A. Barker

R2-11

W. B. Barton

R2-11

J. D. Berger _ . LO-18

M. D. Britton S4-25

K. M. Eager H5-27

K. A. Gasper · G3-21

D. L. Herting T6-09

C. V. King S4-25

R. A. Kirkbride H5-27

M. J. Klem H5-27

D. L. Penwell H5-27

I. E. Reep G3-21

D. J. Washenfelder H5-27 
No. of

Copies

33 Pacific Northwest Laboratory

W. F. Bonner

K9-14

L. A. Bray

K. P. Brooks

T. M. Brouns

G. N. Brown (10)

G. H. Bryan

S. A. Bryan

B. C. Bunker

K. J. Carson

C. D. Carlson

R. J. Elovich

J: A. Franz

J. M. Gephart
No. of

Conies

L. K. Holton . K9-73

T. L. Hubler P8-38

W. L. Kuhn K2-21

D. E. Kurath P7-20

J. P. LaFemina K2-25

M. E. Peterson K2-47

R. K. Quinn K9-69

W. G. Richmond K9-33

L. J. Sealock K2-10

J. T. Slankas K9-81

S. O. Slate $\quad$. P8-44

Technical Report Files (5)

PNL Information Release

Office (7)

K1-11 
